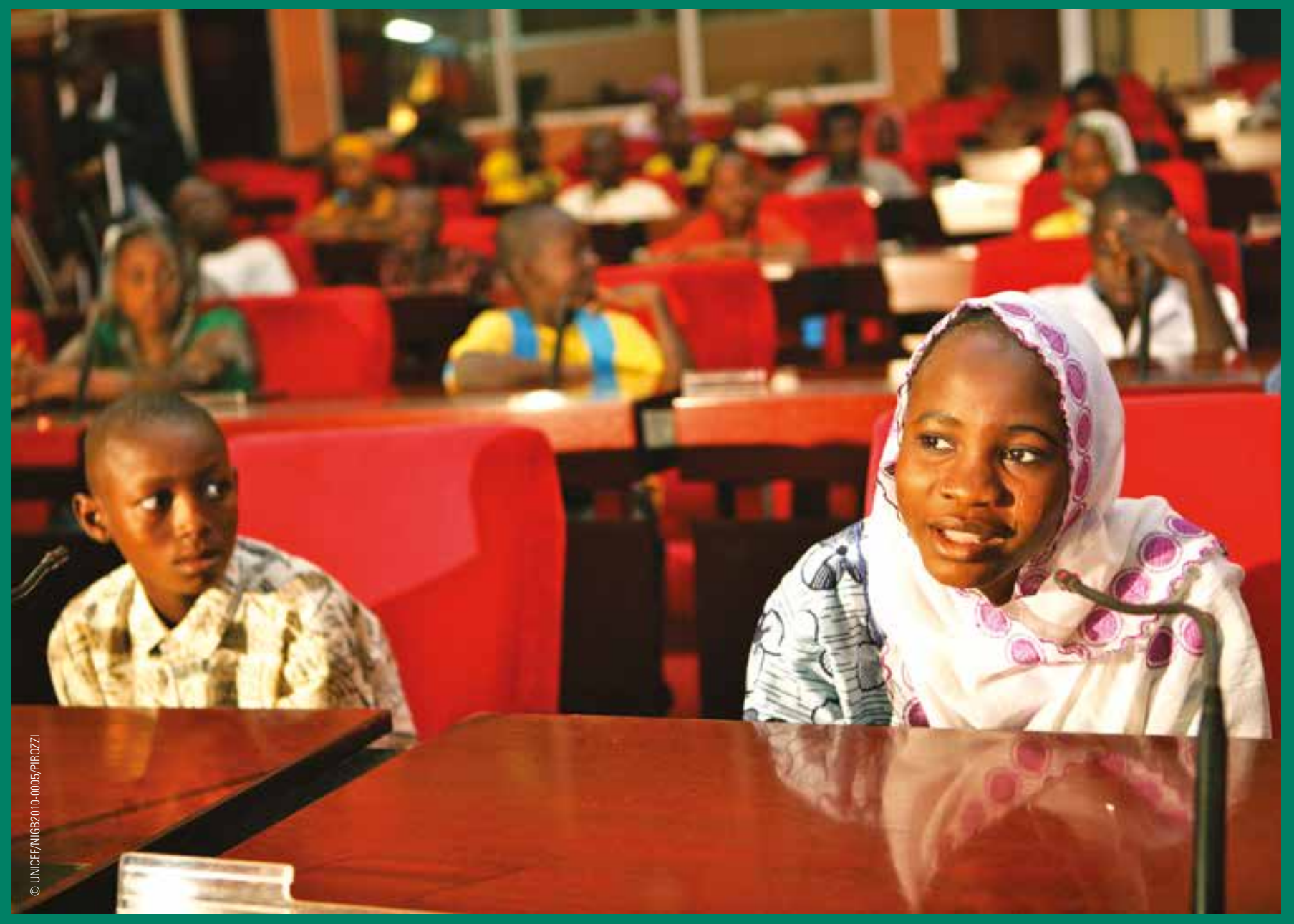

\title{
OBLIGATIONS AND ACTIONS ON CHILDREN'S RIGHTS AND BUSINESS
}

A practical guide for States on how to implement the United Nations Committee on the Rights of the Child's General Comment no. 16 


\section{RESEARCH, WRITING, DESIGN AND EDITING}

UNICEF Corporate Social Responsibility Unit: Maria Pia Bianchetti, Patrick Geary, Bo Viktor Nylund and Beth Verhey UNICEF Private Sector Engagement: Andrés Franco UNICEF Private Fundraising and Partnership Design Unit: James Elrington and Bruno Rocha International Commission of Jurists: Agnès Gràcia Corberó, Benjamin Shea, Carlos Lopez, Clara Pascual de Vargas, Divya Prasad, Ian Seiderman and Olivier van Bogaert

\section{ACKNOWLEDGMENTS}

This publication was elaborated jointly by the International Commission of Jurists and UNICEF at the request of the United Nations Committee on the Rights of the Child. It was developed through a consultative process and benefitted from the expertise of a wide range of contributors, including: Desirée Abrahams, Business and Human Rights Consultant; Hélène de Bock, Ministry of Foreign Affairs, Belgium; Jorge Cardona, United Nations Committee on the Rights of the Child; Eleanor Hevey, UNICEF Canada; Anita Househam, United Nations Global Compact; Irene Leino, Finnish Committee for UNICEF; Peggy Ljubicic, Japan Tobacco International; Marta Maurás, United Nations Committee on the Rights of the Child (former member); Nora Loozen, Ministry of Foreign Affairs, Belgium; Erik Nyman, UNICEF Regional Office for East Asia and the Pacific; and Francis West, UNICEF UK.

This publication was made possible by a grant by the Oak Foundation to the ICJ.

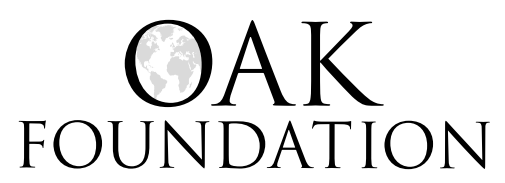

\section{DISCLAIMER AND COPYRIGHT}

All rights to this guide remain with the United Nations Children's Fund (UNICEF) and the International Commission of Jurists (ICJ). No part of this document may be replicated or redistributed without the prior written consent of UNICEF and ICJ.

A reference to a non-UNICEF website does not imply endorsement by UNICEF or ICJ of the accuracy of the information contained therein or of the views expressed. Any reference made to government laws, policies, practices or actions, or to voluntary or other guidelines or standards, does not imply endorsement by UNICEF or ICJ. Rather, these are intended to demonstrate learning examples of how governments are addressing their obligations with respect to children's rights and business.

For more information please visit <www.unicef.org/csr> and <www.icj.org/themes/business-and-human-rights $>$.

(C) 2015 United Nations Children's Fund (UNICEF), Geneva, and International Commission of Jurists (ICJ), Geneva. 


\section{CONTENTS}

FOREWORD

\section{PART ONE - INTRODUCTION}

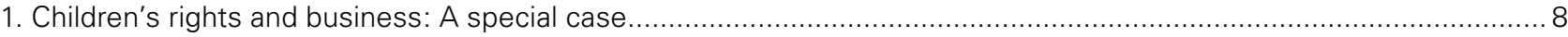

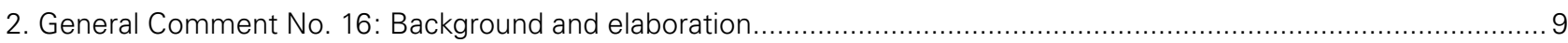

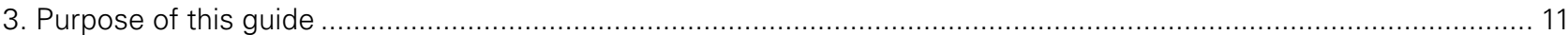

\section{PART TWO - STATE OBLIGATIONS ON BUSINESS AND CHILDREN'S RIGHTS}

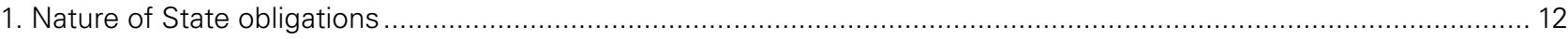

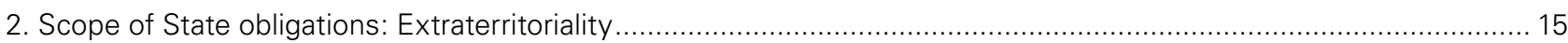

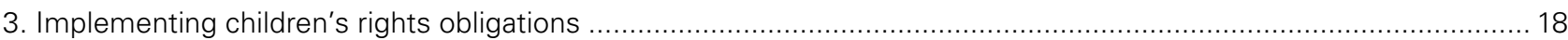

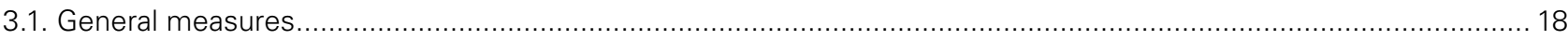

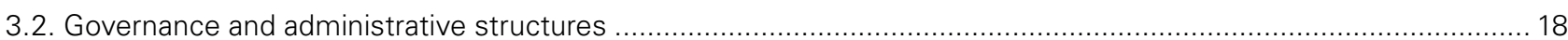

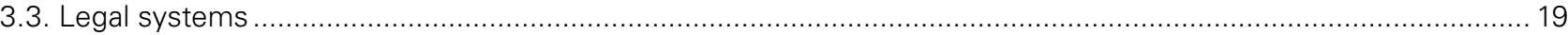

PART THREE - STRATEGIES AND TOOLS TO REGULATE AND INFLUENCE BUSINESS

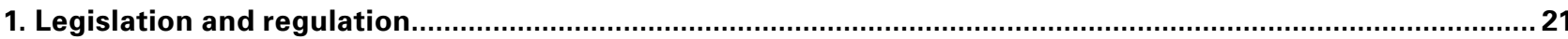

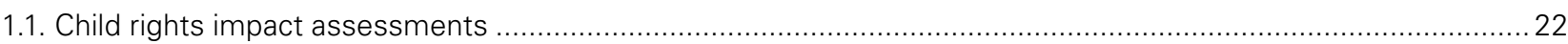

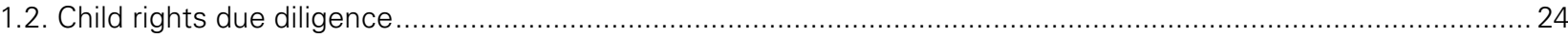

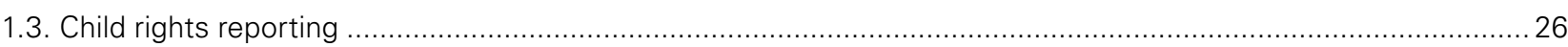

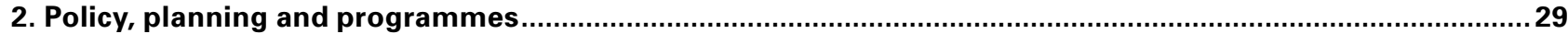

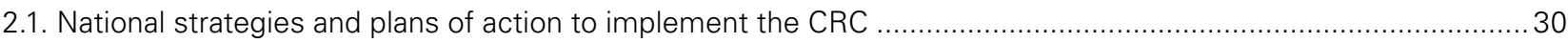

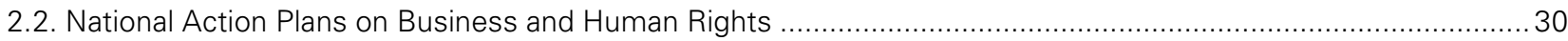

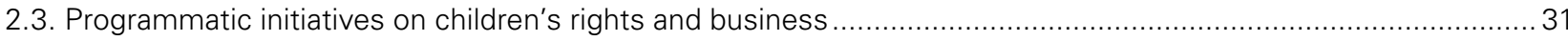

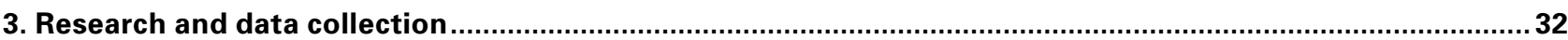

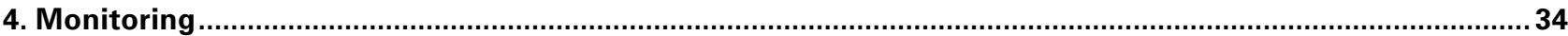

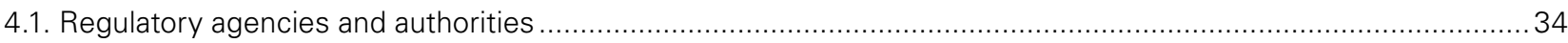

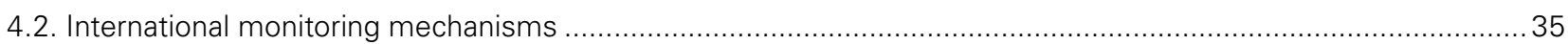

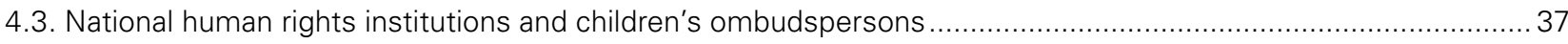

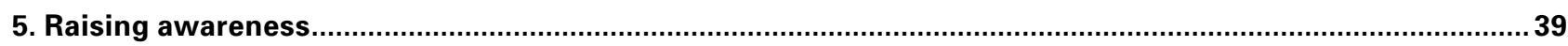

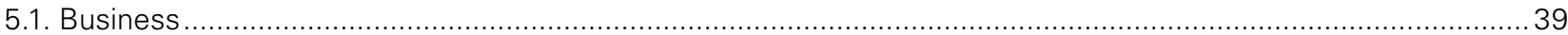

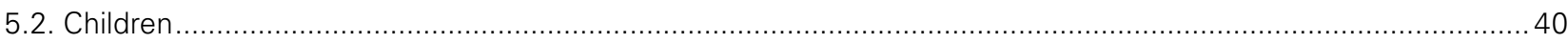

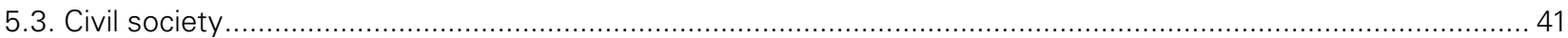

6. Remedies

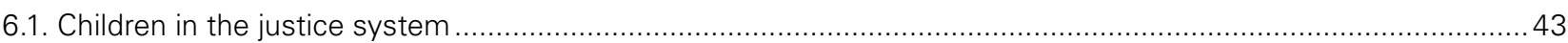

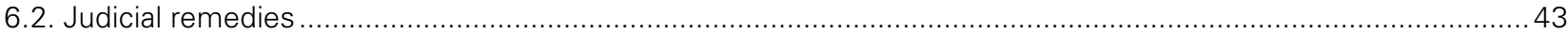

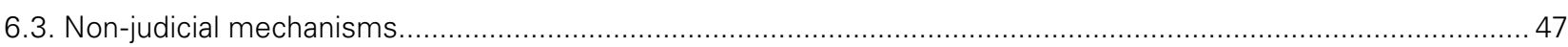

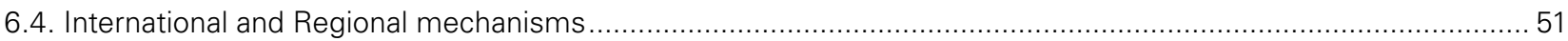

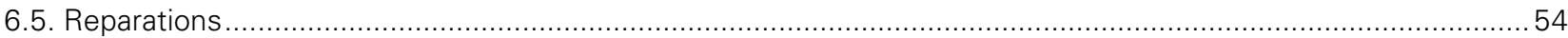

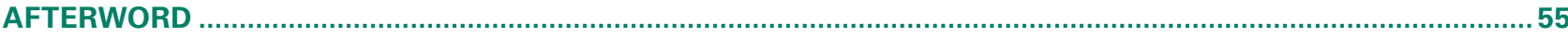

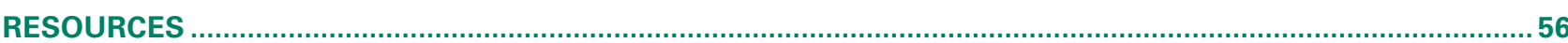




\section{CONTENTS}

\section{LIST OF BOXES}

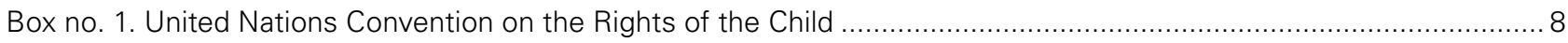

Box no. 2. United Nations Guiding Principles on Business and Human Rights: General Principles ............................... 9

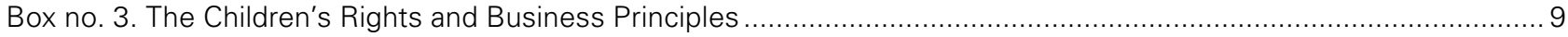

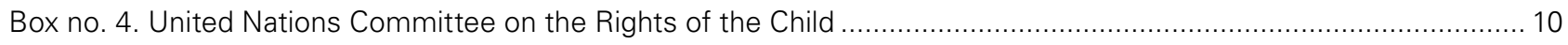

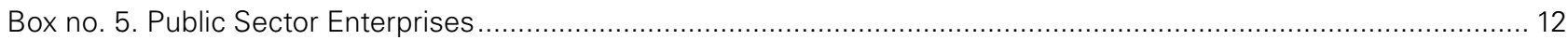

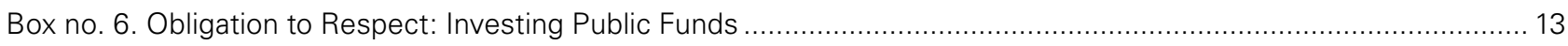

Box no. 7. Obligation to Protect: Marketing and Advertising to Children.................................................................. 13

Box no. 8. Obligation to Fulfil: Decent Working Conditions for Caregivers .................................................... 13

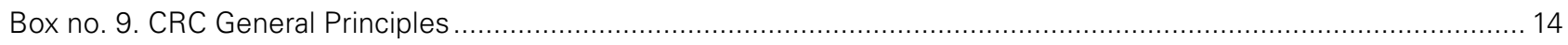

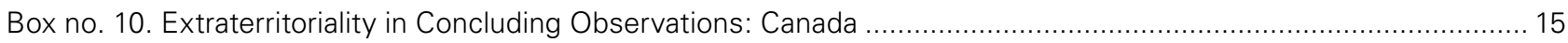

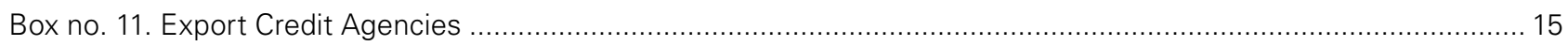

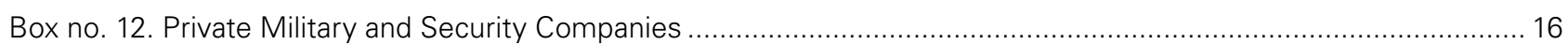

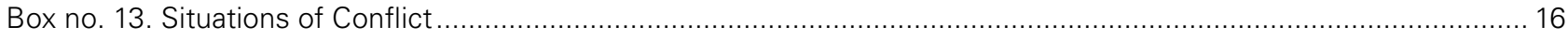

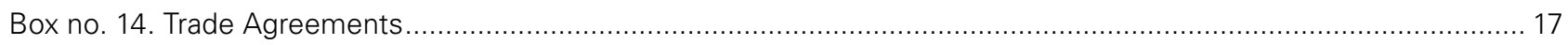

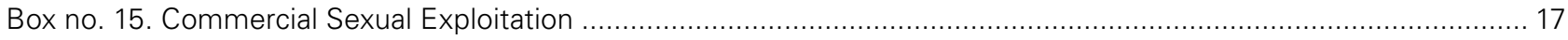

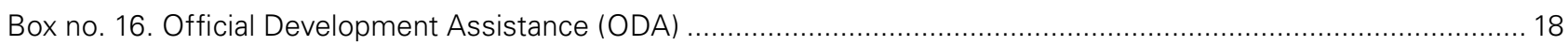

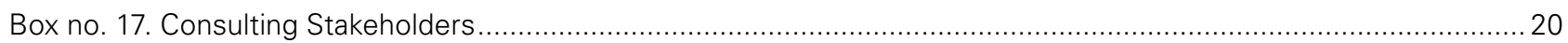

Box no. 18. Legal Frameworks in Concluding Observations: Morocco …................................................... 21

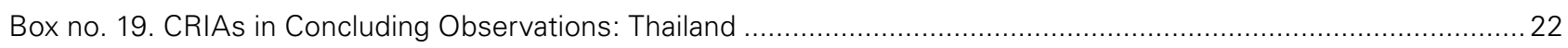

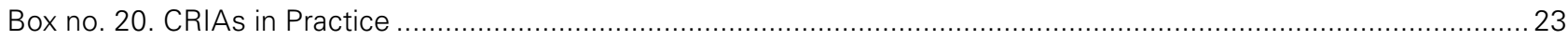

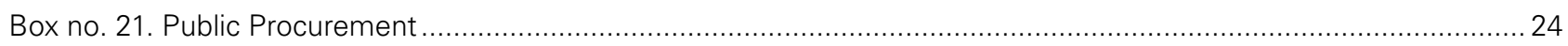

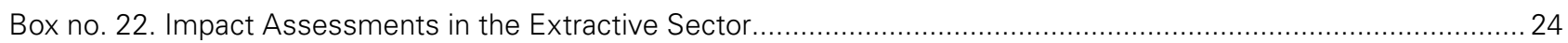

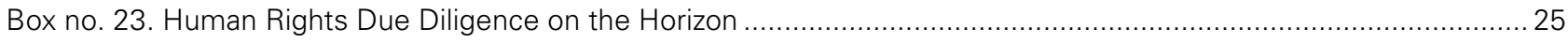

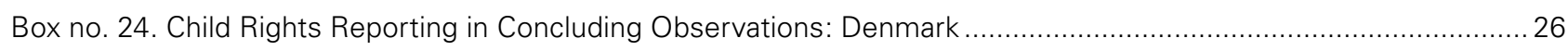

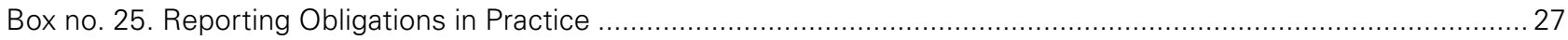

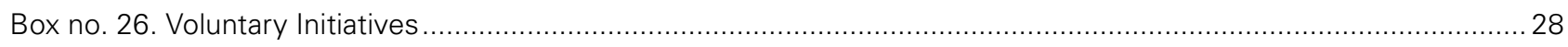

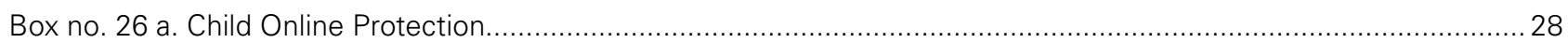

Box no. 26 b. Voluntary Initiatives in Concluding Observations: Panama ......................................................... 28

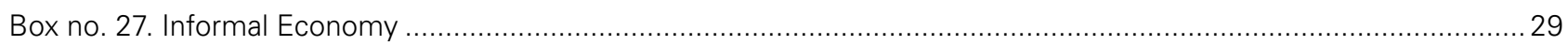

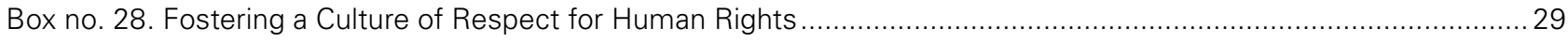

Box no. 29. Children's Rights in National Action Plans on Business and Human Rights ........................................... 31

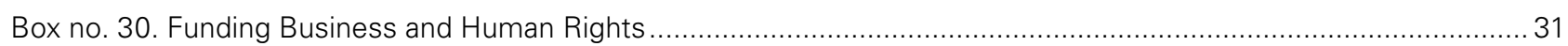

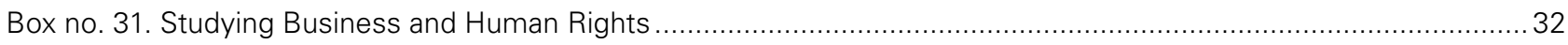

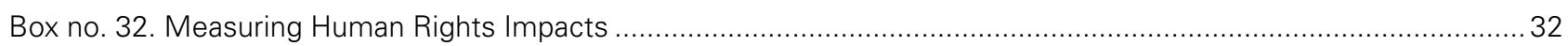

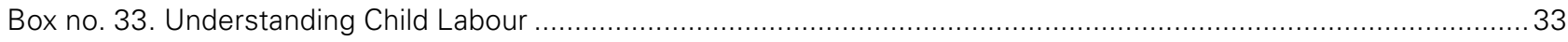

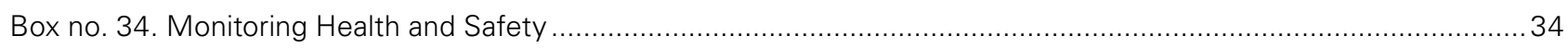

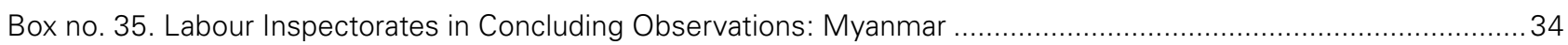

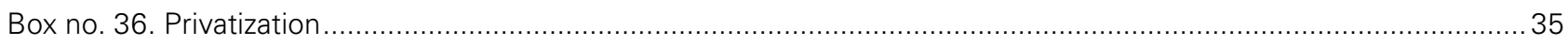

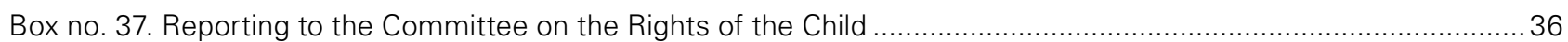

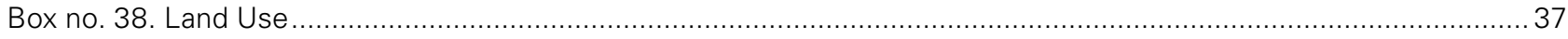

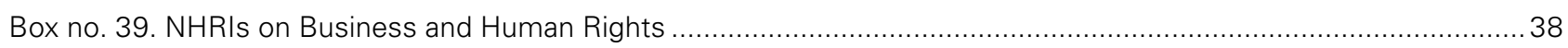

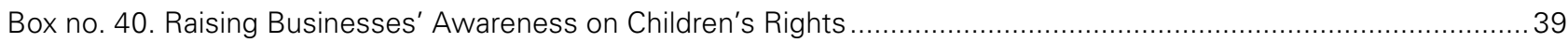

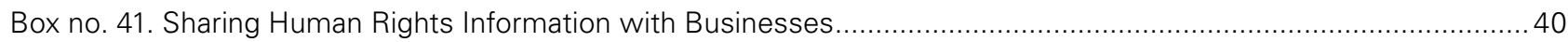




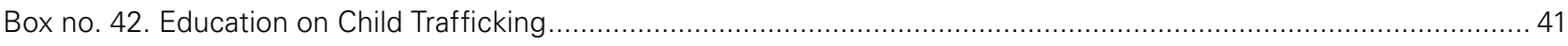

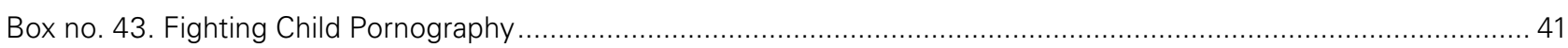

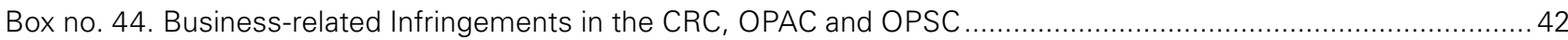

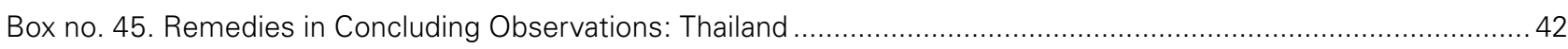

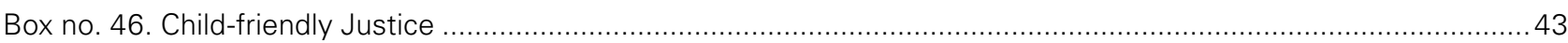

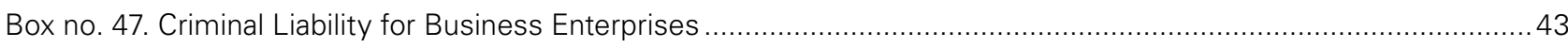

Box no. 48. Overcoming Barriers to Access to Justice for Children..................................................................44

Box no. 49. Effectiveness Criteria for Non-Judicial Mechanisms ................................................................ 48

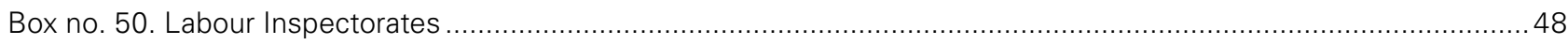

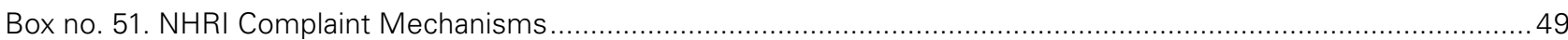

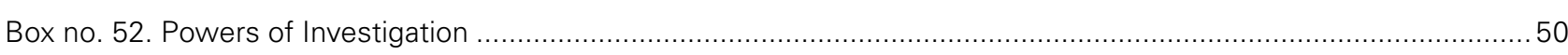

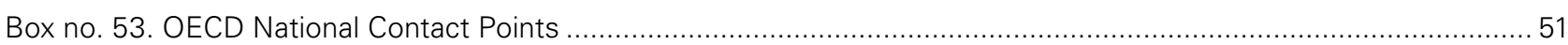

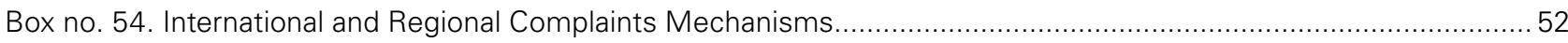

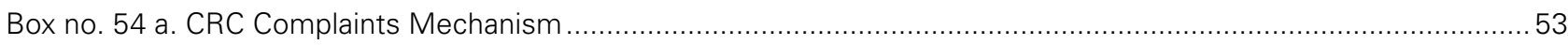

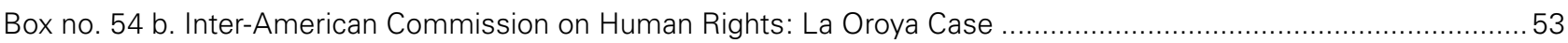

Box no. 54 c. European Committee of Social Rights: Child Labour in Portugal ..................................................... 53 


\section{FOREWORD}

The business sector has a growing impact on the realization of children's rights. There is great potential for positive effects when business enterprises are aware of their important role in this respect, and the possible negative effects must be avoided. Children are future workers, current consumers and targets of business marketing. It is necessary that the business sector care about children and promote their rights, and that States enable them to do so while at the same time protecting children's rights against possible infringements and punishing abusive practices.

We have seen progress at the national and international levels; the importance of the issue is recognized not only by States and other actors, but by business enterprises themselves. This has translated into more action and concrete initiatives. With the aim of providing practical guidance to States parties to the United Nations Convention on the Rights of the Child on the application of this Convention and its Optional Protocols in the context of business operations, the Committee on the Rights of the Child elaborated General Comment no. 16.

It is particularly timely and useful that UNICEF and the International Commission of Jurists have jointly developed this guide on the implementation of General Comment no. 16. The Committee is thankful to both organizations for their dedication and expertise, and congratulates them on the result. The guide will be very useful not only for States and business enterprises, but also for the Committee in its examination of States parties' reports and in formulating its recommendations.

In operationalizing General Comment no. 16, the guide provides very relevant examples of laws, policies and measures adopted by States that can inspire and guide other States in their efforts to protect and realize the rights of the child in the context of business operations. Hopefully, it will also encourage business enterprises to become more involved in this task.

\section{Kirsten Sandberg}

Chairperson, Committee on the Rights of the Child 


\section{LIST OF ABBREVIATIONS}

CRC

United Nations Convention on the Rights of the Child

CRIA

Child rights impact assessment

CRPBs

Children's Rights and Business Principles

CSR

Corporate social responsibility

GC

General Comment

HRC

United Nations Human Rights Council

IACHR

Inter-American Commission on Human Rights

ICCPR

International Covenant on Civil and Political Rights

NHRIs

National human rights institutions

ODA

Official development assistance

OECD

Organisation for Economic Co-operation and Development

OPAC

Optional Protocol to the United Nations Convention on the Rights of the Child on the involvement of children in armed conflict

OPIC

OPSC

Optional Protocol to the United Nations Convention on the Rights of the Child on a communications procedure

PMSCs

Optional Protocol to the United Nations Convention on the Rights of the Child on the sale of children, child prostitution and child pornography

UN Private military and security companies

UNGPs United Nations

UNICEF United Nations Guiding Principles on Business and Human Rights United Nations Children's Fund 


\section{PART ONE}

\section{Children's rights and business: A special case}

United Nations

\section{Box 1}

\section{Convention on the}

Rights of the Child

Adopted by the United Nations General Assembly in 1989, the Convention on the Rights of the Child (CRC) enshrines a comprehensive set of civil, political, economic, social and cultural rights for all children. ${ }^{1}$ The $\mathrm{CRC}$ is the most widely ratified or acceded to of the core international human rights treaties - which are also applicable to children - and a full 195 States have now committed to implementing its provisions through laws, policies, plans and programmes. ${ }^{2}$ It is thus national governments' primary responsibility to protect, respect and fulfil children's rights as set out in the 40 substantive articles of the CRC. As part of this, governments must also support, guide and direct others who play important roles in children's lives including parents, teachers, caregivers, and increasingly - businesses.

The CRC is complemented by three additional instruments: the Optional Protocol on the sale of children, child prostitution and child pornography $(\mathrm{OPSC}){ }^{3}$ the Optional Protocol on the involvement of children in armed conflict (OPAC); ${ }^{4}$ and the Optional Protocol on a communications procedure (OPIC). ${ }^{5}$ The OPSC and OPAC set out more detailed obligations with regard to specific children's rights issues, while the communications procedure allows children to seek a non-judicial remedy before the Committee on the Rights of the Child for violations of their rights.
More than ever before, business enterprises have an impact on children's lives. Children are consumers of businesses' products and services, workers in their factories and fields, family members of their employees, and residents of the communities that host their operations. Some of these interactions can benefit children. Companies have, for instance, created new technologies that enrich children's education, enhance medical care, and connect families around the world. Yet at the same time, businesses can also have detrimental impacts. Companies can make and sell unhealthy and unsafe goods to children, pollute the environments in which children live and play, and expose them to serious dangers in the workplace.

As children are still growing and developing, they are especially vulnerable to negative business impacts and can be severely and permanently affected by infringements of their rights. Child consumers can be more easily convinced to buy and use inappropriate or unsuitable products, and children are much more susceptible than adults to the harmful physical effects of toxic chemicals, manual labour and poor diets. Young workers can never fully make up for time spent out of education, and missed opportunities are rarely restored.

Many of these impacts remain invisible, and businesses rarely involve or seek the input of children on decisions that will profoundly affect them. Children may not understand that their rights are in jeopardy, and, even when they do, often face tremendous challenges in making their voices heard. All too frequently, child victims lack the confidence, resources and legal authority to demand accountability from those who violate their rights.

For these reasons, it is imperative that governments take action to protect and promote children's rights in the context of business operations. Recognizing this need, the United Nations Committee on the Rights of the Child has for many years drawn States' attention to business impacts on children, both within and outside their borders. It now offers an ideal, international framework for understanding what governments can, should and must do to make certain that businesses respect children's rights as envisioned in the Convention on the Rights of the Child.

1 Article 1 of the Convention defines a child as "every human being below the age of 18 years unless under the law applicable to the child, majority is attained earlier".

2 To see the up-to-date list of States that have ratified the Convention on the Rights of the Child, refer to $<$ https://treaties.un.org/Pages/ViewDetails. aspx? src=TREATY\&mtdsg_no=IV-11\&chapter=4\&lang $=$ en $>$, accessed 8 October 2014 .

3 To see the up-to-date list of States that have ratified the Optional Protocol to the Convention on the Rights of the Child on the sale of children, child prostitution and child pornography, refer to <https://treaties.un.org/pages/ViewDetails.aspx?src=TREATY\&mtdsg_no=IV-11c\&chapter $=4 \&$ lang $=$ en $>$, accessed 8 January 2015.

4 To see the up-to-date list of States that have ratified the Optional Protocol to the Convention on the Rights of the Child on the involvement of children in armed conflict, refer to <https://treaties.un.org/pages/ViewDetails.aspx?src=TREATY\&mtdsg_no=IV-11-b\&chapter=4\&lang=en>, accessed 8 January 2015.

5 To see the up-to-date list of States that have ratified the Optional Protocol to the Convention on the Rights of the Child on a communications procedure, refer to <https://treaties.un.org/pages/ViewDetails.aspx?src=TREATY\&mtdsg_no=IV-11-d\&chapter=4\&lang=en>, accessed 8 January 2015. 


\section{General Comment no. 16: Background and elaboration}

Business responsibilities towards human rights have received increasing international attention over the past decade. Following on work by the United Nations Sub-Commission on the Protection and Promotion of Human Rights to elaborate human rights norms and principles applicable to business enterprises, the former United Nations Human Rights Commission ${ }^{6}$ in 2005 established a mandate for the Special Representative of the Secretary General on Human Rights and Transnational Corporations and Other Business Enterprises. Professor John Ruggie was appointed, and the Commission called on the Special Representative, among other things, to "identify and clarify standards of corporate responsibility and accountability for transnational corporations and other business enterprises with regard to human rights". ${ }^{7}$

After an extended period of research and consultation with governments, companies, business associations, civil society and other stakeholders, the work of the Special Representative culminated in 2011 with the Human Rights Council's consensual endorsement of the United Nations Guiding Principles on Business and Human Rights (UNGPS). The Guiding Principles are based on three pillars: the State duty to protect human rights ('Protect'); the corporate responsibility to respect human rights ('Respect'); and the shared obligation to provide victims of corporate human rights abuse with an effective remedy ('Remedy').

The Human Rights Council (HRC) has since established a Working Group on business and human rights to disseminate and facilitate the implementation of the UNGPs by, among other things, identifying, exchanging and promoting good practices. In June 2014, the HRC also established an Intergovernmental Working Group to begin discussions on a binding treaty on business and human rights. ${ }^{9}$

Importantly, the HRC's actions and the UNGPs in particular have inspired greater interest by international actors in business and children's rights. In 2012, UNICEF, Save the Children and the United Nations Global Compact released the Children's Rights and Business Principles. ${ }^{10}$ These Principles call on business everywhere to respect and support children's rights throughout their activities, operations and business relationships in the workplace, the marketplace, the community and the environment. They can, among other things, be used to inform governments' expectations of and engagements with businesses.

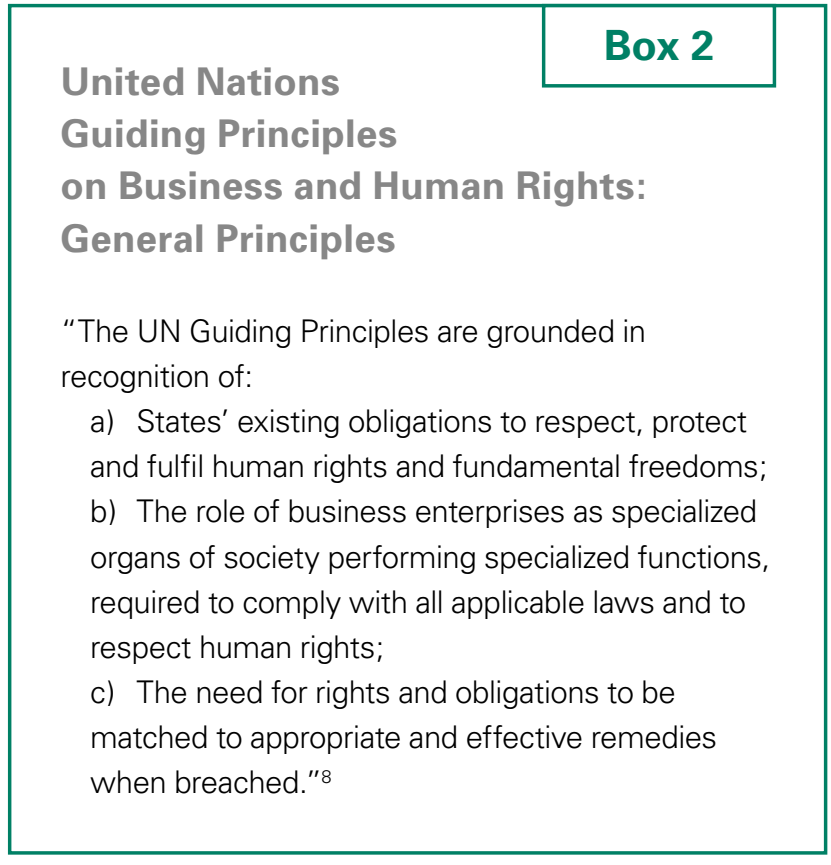

The Children's Rights

\section{Box 3}

and Business Principles ask

\section{all business to:}

1. Meet their responsibility to respect children's rights and commit to supporting the human rights of children.

2. Contribute towards the elimination of child labour, including in all business activities and business relationships.

3. Provide decent work for young workers, parents and caregivers.

4. Ensure the protection and safety of children in all business activities and facilities.

5. Ensure that products and services are safe, and seek to support children's rights through them.

6. Use marketing and advertising that respect and support children's rights.

7. Respect and support children's rights in relation to the environment and to land acquisition and use.

8. Respect and support children's rights in security arrangements.

9. Help protect children affected by emergencies.

10. Reinforce community and government efforts to protect and fulfil children's rights.

6 The United Nations Human Rights Commission was the predecessor body to the Human Rights Council.

7 United Nations Commission on Human Rights, Human Rights Resolution 2005/69, Human Rights and transnational corporations and other business enterprises, UN Doc. E/CN.4/RES/2005/69, 20 April 2005.

8 Guiding Principles on Business and Human Rights: Implementing the United Nations 'Protect, Respect and Remedy' Framework (UNGPs), annexed to Report of the Special Representative of the Secretary-General on the issue of human rights and transnational corporations and other business enterprises, General Principles, A/HRC/17/31, available at <www.ohchr.org/Documents/Publications/GuidingPrinciplesBusinessHR_EN.pdf>.

9 Human Rights Council, Resolution 26/9, Elaboration of an international legally binding instrument on transnational corporations and other business enterprises with respect to human rights, UN Doc. A/HRC/RES/26/9, 26 June 2014.

10 United Nations Children's Fund, United Nations Global Compact and Save the Children, Children's Rights and Businesses Principles, <http:// childrenandbusiness.org>, accessed 8 October 2014 


\section{United Nations}

\section{Box 4}

\section{Committee on the}

\section{Rights of the Child}

The United Nations Committee on the Rights of the Child is composed of 18 independent experts tasked with monitoring the implementation of the CRC and its Optional Protocols." To facilitate this, States that are party to the Convention are required to submit periodic reports to the Committee on how they are discharging their children's rights obligations. ${ }^{12}$ The Committee then reviews these reports, as well as alternative reports or other information received from civil society, engages in interactive dialogues with government officials, and issues recommendations known as 'Concluding Observations'. Outside this process, the Committee can receive information on alleged violations of children's rights as set out in the OPIC and in a quasi- judicial capacity issue opinions on whether violations have occurred and, if so, what redress should be afforded to the victim(s).

The Committee also provides overall guidance to assist States in realizing children's rights. It organizes Days of General Discussion, which bring together international organizations, academics, civil society actors, businesses and other interested parties to debate topics of importance to children's rights. The Committee also publishes "General Comments" to provide in-depth explanations of particular provisions and explore themes or issues relevant to children's rights more broadly. General Comments include legal analysis, policy direction and suggested best practices, and are considered authoritative sources of treaty interpretation. To date, the Committee has issued 18 General Comments on a wide range of issues relevant to the implementation of the Convention. ${ }^{13}$
In this context, the Committee on the Rights of the Child set out to provide governments with specific guidance on the role of the private sector. To do this, the Committee launched a series of online and in-person consultations to build broad consensus for its work. Input was sought from a wide range of stakeholders, including State representatives, civil society organizations, academics, business and children. Drafts were publicly presented and discussed, and an international conference was held to foster vigorous discussion.

The Committee adopted General Comment no. 16 on State obligations regarding the impact of the business sector on children's rights (GC 16) in February 2013. GC 16 is addressed to all States that have ratified the CRC, OPAC and/or OPSC, and broadly covers all national and transnational business enterprises, irrespective of their size, sector, location, ownership and structure. Notably, GC 16 also covers the role of non-profit organizations that are engaged in providing services for the enjoyment of children's rights.

The main thrust of GC 16 is that States have a legal obligation to ensure that private sector enterprises respect the rights of the child; that they do not hinder efforts to realize and advance children's rights, whether directly or indirectly, intentionally or inadvertently; and that they engage positively in the realization of those rights.

11 See Convention on the Rights of the Child, article 43 ("For the purpose of examining the progress made by States Parties in achieving the realization of the obligations undertaken in the present Convention, there shall be established a Committee on the Rights of the Child...").

12 See Convention on the Rights of the Child, article 44 ("States Parties undertake to submit to the Committee... reports on the measures they have adopted which give effect to the rights recognized [in the Convention on the Rights of the Child] and on the progress made on the enjoyment of those rights...").

13 For an up-to-date list of the General Comments adopted by the Committee on the Rights of the Child, consult <http://tbinternet.ohchr.org/_layouts/ treatybodyexternal/TBSearch.aspx? Lang=en\&TreatyID =5\&DocTypeID=11>, accessed 22 December 2014. 


\section{Purpose of this guide}

This guide aims to support governments and other competent State institutions in the implementation of the CRC and its Optional Protocols with respect to the business sector as elaborated in GC 16. It details the obligations of States with regard to business and children's rights, and explains how these obligations can be fulfilled. Specifically, the guide provides advice on how States can prevent, investigate, sanction and redress children's rights abuses through legislation and administrative regulation; policies, plans and programmes; research and data collection; monitoring and oversight; awareness raising; and remedial measures. To better illustrate these tools and strategies, the guide also highlights relevant examples of national, regional and international laws and practices, and includes excerpts from the text of GC 16 and related recommendations throughout. 


\section{STATE OBLIGATIONS ON BUSINESS AND CHILDREN'S RIGHTS}

\section{Nature of State obligations}

As reaffirmed in GC 16, States have distinct obligations under the CRC to respect, protect and fulfil children's rights in relation to the business sector, ${ }^{14}$ and to make available effective remedies for violations and infringements of these rights.

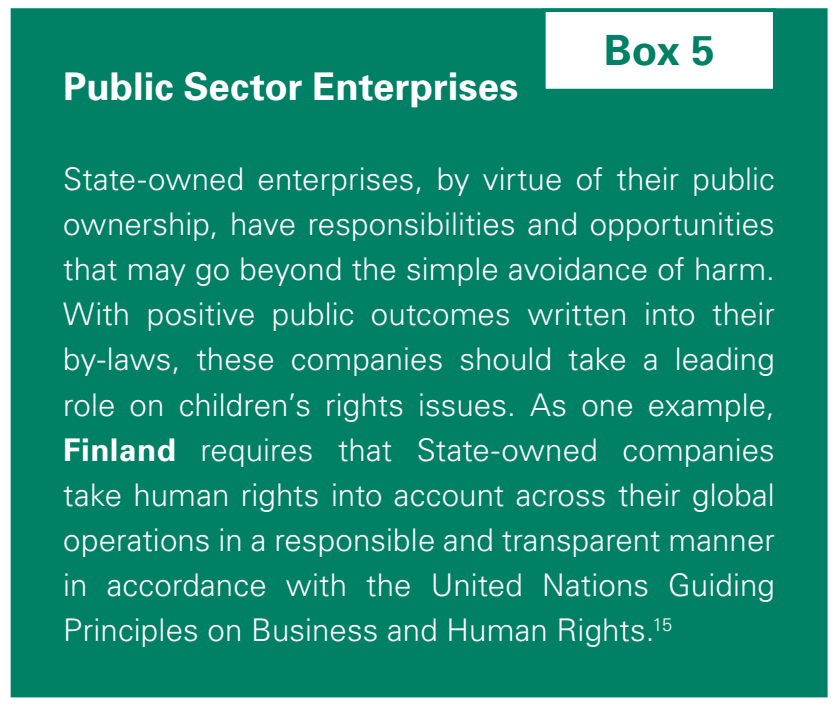

The obligation to respect children's rights requires that States not interfere with the enjoyment of these rights, and applies when governments support, act as or enter into a relationship with a business. Public sector enterprises should have a clear understanding of their responsibility to operate in ways that comply with children's rights, and governments must ensure that external business practices and relations are carried out in furtherance of children's rights by, for instance, exercising vigilance in hiring and supervising public contractors.

The obligation to respect also requires business-related laws, policies and decisions to be "transparent, informed and include full and continuous consideration of the impact on the rights of the child"16 such that States do not directly or indirectly facilitate corporate infringements of children's rights.

The obligation to protect children against infringements of their rights requires States to adopt all necessary, appropriate and reasonable measures to prevent third parties, including businesses, from intentionally or inadvertently causing or contributing to children's rights abuses. Specifically, States must establish and enforce legal frameworks and adopt policies that effectively prevent, address and sanction negative business impacts on children's rights, taking additional measures as necessary to guarantee the rights of children in vulnerable situations.

The obligation to fulfil requires States to facilitate, promote and provide for the enjoyment of children's rights. States must put in place legislative, administrative, budgetary, judicial, promotional and other measures to "ensure the best environment for full realization of the Convention and the Optional Protocols". These measures should look holistically at the ways that businesses can affect children's lives, foster a business culture of respect for children's rights, and reach across all government agencies, ministries and departments with mandates that touch on business or human rightsrelated issues.

Finally, States have the obligation to provide for, facilitate and support access to effective judicial and non-judicial remedies for children and their families whose rights have been infringed by business enterprises. This includes not only children who are present in a State's territory, but also those who are affected by the activities of a transnational business based or operating in that State. In the case of the latter, States should ensure the effectiveness of investigation and enforcement proceedings, including through international assistance and cooperation.

14 In discussing these obligations, the Committee references the General Comment issued by the Committee on Economic, Social and Cultural Rights on the right to education, which states that this right, "like all human rights, imposes three types or levels of obligations on State parties: the obligations to respect, protect and fulfil. In turn, the obligation to fulfil incorporates both an obligation to facilitate and an obligation to provide." Committee on Economic, Social and Cultural Rights, General Comment no. 13: The Right to Education (art. 13 of the Covenant), UN Doc. E/C.12/1999/10, 8 December 1999, para. 46. Notably, the Committee on Economic, Social and Cultural Rights first presented these concepts in earlier General Comment no. 12: The right to adequate food (art. 11), UN Doc. E/C.12/1999/5, 12 May 1999, paras. 14-20.

15 Finnish Government, National Action Plan on Business and Human Rights, Government covering note on the United Nations Guiding Principles on Business and Human Rights National Action Plan, <www.tem.fi/files/41214/TEMjul_46_2014_web_EN_21102014.pdf>, accessed 19 January 2015.

16 Committee on the Rights of the Child, General Comment no. 16 on State obligations regarding the impact of the business sector on children's rights, UN Doc. CRC/C/GC/16, 17 April 2013, para. 26. 


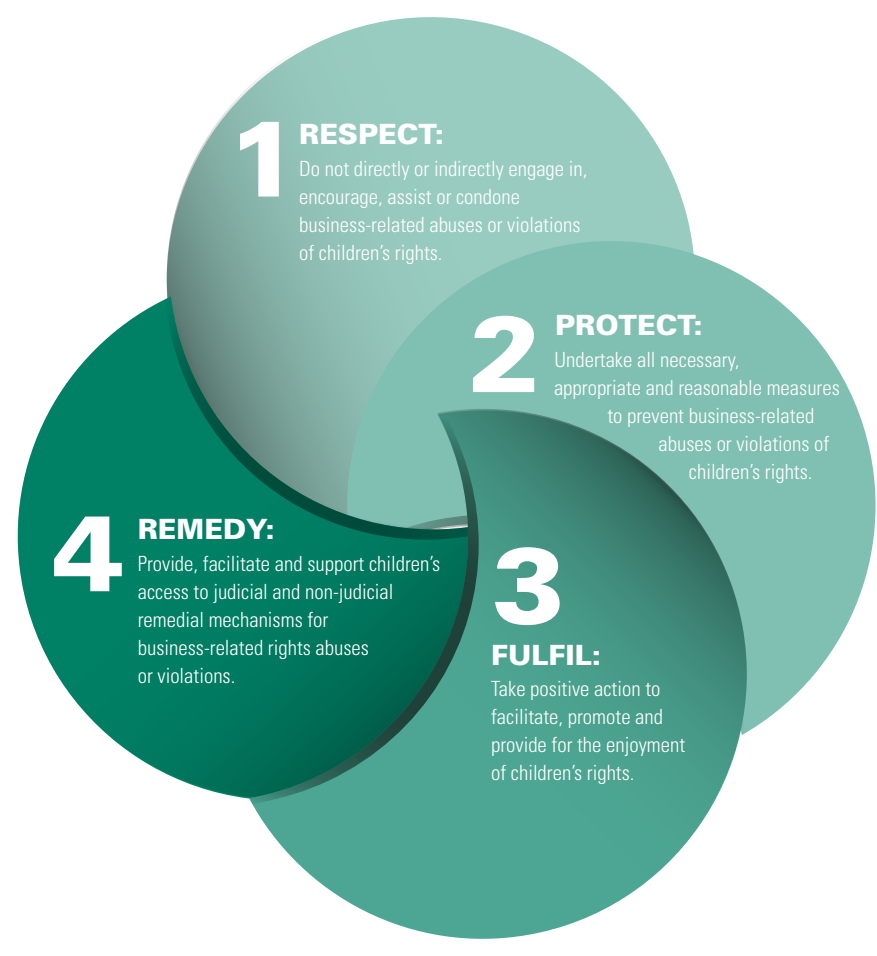

Obligation to Respect:

Box 6 Investing Public Funds

Some governments invest substantial financial assets in the private sector through, for instance, sovereign wealth and pension funds. These investments can fund business projects and activities with negative impacts on children's rights, and may indirectly support the use of child labour, the recruitment of children into security forces, environmental degradation and its adverse impacts on health and well-being, and many other possible rights abuses. To address these concerns, Norway's Norges Bank Investment Management (NBIM), which invests the assets of the Government Pension Fund, explicitly looks at how companies manage their impacts on children's rights in its investment selection criteria. NBIM conducts annual assessments to review progress in meeting these, and has also developed a set of expectations for investors on how companies can address the worst forms of child labour and promote children's rights within their operations and supply chains. ${ }^{17}$

\section{Box 7}

\section{Obligation to Protect:}

(B)
Marketing and Advertising to Children

As a valuable consumer market, children are increasingly exposed to commercial messages through traditional, digital and social media. At the same time, evidence shows that many children are less able to objectively evaluate potentially harmful advertising and marketing messages. Companies may promote products and behaviours that are dangerous or unhealthy for children, negatively impacting on their rights to health, development and protection from violence. For these reasons, Sweden has banned advertising to children under 12 in certain media. ${ }^{18}$ Denmark also heavily regulates marketing and advertising to children. Among other restrictions, companies are prohibited from advertising tobacco, drugs and alcohol to children, and marketing messages cannot encourage reckless behaviour, misrepresent the nutritional content of food and beverages, or portray unrealistic body images. ${ }^{19}$

\section{Obligation to Fulfil: Decent Working Conditions for Caregivers}

Hazardous, demanding and unsuitable working conditions can undermine parents' and caregivers' abilities to help their children grow and develop to reach their full potential. These conditions may, among other things, make it difficult for working mothers of infants and babies to find time and space to breastfeed, prompting El Salvador to enact a law promoting breastfeeding in the workplace. Under the law, mothers are permitted paid lactation breaks, and employers must designate suitable, safe and hygienic places for breastfeeding. The government is tasked with conducting regular audits and inspections, and has powers to sanction companies that do not comply with their obligations. ${ }^{20}$

17 For more information, consult <www.nbim.no/en/responsibility/responisble-investments/childrens-rights/>, accessed 19 October 2014.

18 Section 7 of the Radio and Television Act, Ministry of Culture, Sweden, 2010, <www.radioochtv.se/documents/styrdokument/radio\%20 and\%20television\%20act.pdf>, accessed 3 November 2014, cited in World Health Organization, A framework for implementing the set of recommendations on the marketing of foods and non-alcoholic beverages to children, WHO, Switzerland, 2012, p. 22, <http://apps.who.int/iris/ bitstream/10665/80148/1/9789241503242_eng.pdf?ua=1>, accessed 22 October 2014.

19 Danish Consumer Ombudsman, Children, Young People and Marketing Practices, <www.consumerombudsman.dk/?SC_itemid=801ff5ab-c7744529-8a41-d6e933cd13b0\#>, accessed 17 October 2014

20 For the text of the law in Spanish, consult <https://extranet.who.int/nutrition/gina/sites/default/files/SLV\%202013\%20Ley\%20de\%20 Promocion\%2C\%20Protection\%20y\%20Apoyo\%20a\%20la\%20Lactancia\%20Materna_0.pdf>, accessed 17 October 2014. 
While it must be understood that all children's rights are universal, indivisible, interdependent and interrelated, State obligations in this respect can be viewed through the lens of four broadly applicable rights identified by the Committee on the Rights of the Child as being of particular importance in understanding, interpreting and implementing the CRC. These four rights, known as "general principles", are: 1) the right to non-discrimination; 2 ) the best interests of the child; 3) the right to life, survival and development; and 4) the right of the child to be heard. These general principles should underpin and inform all State measures concerning children, including those directed towards business activities that have an impact on children's rights.

\section{CRC General Principles}

\section{The right to non discrimination (CRC article 2)}

Each child has the right to be treated without discrimination of any kind regardless of the child or his/her parent's or legal guardian's race; colour; sex; language; religion; political or other opinion; natural, ethnic or social origin; property; disability; birth or other status.

Governments should make sure that business-related laws, policies and decisions do not unfairly impact children as a whole or particular groups of children, and should take measures to ensure that all children are able to benefit equally from business products and services that contribute to the realization of their rights.

\section{The best interests of the Child} (CRC article 3)

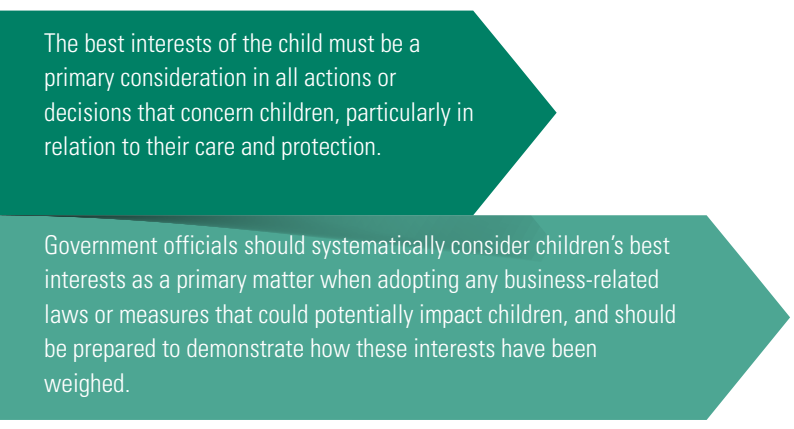

\section{The right of the child to be heard} (CRC article 12)

\section{(CRC article 6)}

All children have an inherent right to life, survival and development. Their physical, mental spiritual, moral, psychological and social development must be ensured to the maximum possible extent.

Governments should take steps to ensure all aspects of children's development, seeking to prevent, mitigate and remediate actual and potential negative business impacts across the workplace, the marketplace, the community and the environment.
Children have the right to freely express thei views in all matters affecting them and the

right to have their views taken into

consideration in accordance with their age and maturity.

Governments should seek and give due weight and consideration to children's freely expressed views on business-related laws, policies and decisions which may impact them, and should provide guidance to businesses on engaging with children likely to be affected by their activities or operations. 


\section{Scope of State obligations: Extraterritoriality}

\section{Extraterritoriality in \\ Concluding Observations: Canada \\ Box 10}

"The Committee recommends that the State party establish and implement regulations to ensure that the business sector complies with international and national human rights, labour, environment and other standards...In particular, it recommends that the State party ensure:

(a)The establishment of a clear regulatory framework for, inter alia, the gas, mining, and oil companies operating in territories outside Canada to ensure that their activities do not impact on human rights or endanger environment and other standards, especially those related to children's rights;

(b)The monitoring of implementation by companies at home and abroad of international and national environmental and health and human rights standards and that appropriate sanctions and remedies are provided when violations occur with a particular focus on the impact on children..."21

\section{Export Credit Agencies}

\section{Box 11}

Export credit agencies provide loans, guarantees, insurance and other forms of financial support to companies based within their jurisdiction and doing business abroad, often in emerging economies. While the private sector can be an important engine for growth, export credit agencies also risk contributing to business activities that negatively impact children's rights abroad. Accordingly, governments should review the potential implications of overseas business plans before extending financial support. In Denmark, for instance, the national export credit agency (EKF) conducts social and environmental impact assessments for all proposed projects. These assessments are based on international standards, and criteria specifically contemplate the use of child labour. EKF also includes clauses requiring respect for human rights in agreements for major projects and those that pose particularly high risks. ${ }^{22}$

"States have the obligation to respect and ensure children's rights within their jurisdiction. The [CRC] does not limit a State's jurisdiction to 'territory'. In accordance with international law, the Committee has previously urged States to protect the rights of children who may be beyond their territorial borders. It has also emphasized that State obligations under the Convention and the Optional Protocols thereto apply to each child within a State's territory and to all children subject to a State's jurisdiction."

-General Comment no. 16, para. 39

As the forces of globalization grow stronger, business is increasingly done on an international scale. Companies have accordingly spread their activities and operations across borders, often through complicated legal structures and relationships with subsidiaries, suppliers, contractors and licensees. Regardless of the precise nature of a company's global operations, the complexity and international nature of business raise many challenges to ensuring respect for children's rights in all activities, operations and relationships.

It is clear that the global operations of business require a global response, and States must seek to exert their authority and influence with companies wherever they lie along the value chain. The obligations under the CRC, OPAC and OPSC apply to both States that are 'home' to a business and to those that 'host' its operations. All States, whether they are home to or host to businesses, have obligations to respect, protect and fulfil children's rights, and to provide access to justice for infringements thereof. It is simply the leverage and tools available to direct, control and influence business behaviour that vary.

The Committee on the Rights of the Child, in accordance with the United Nations Charter and other human rights instruments, emphasizes that States have a general obligation to engage in international cooperation to realize children's rights. ${ }^{23}$ States have the obligation to implement the Convention and its Optional Protocols not only within their borders, but also sometimes extraterritorially, particularly in situations where they exercise authority or effective control.24 This includes taking measures to address the conduct of non-State actors like global business enterprises registered, domiciled, headquartered or engaged in substantial activities in a State's territory that may negatively impact children's rights in other countries. ${ }^{25}$

21 Committee on the Rights of the Child, Concluding Observations to Canada, UN Doc. CRC/C/CAN/CO/3-4, 6 December 2012, para. 29.

22 For more information, consult EKF, 2013 CSR Report, <www.ekf.dk/Docs/ EKF\%20CSR\%202013\%20-\%20Final.pdf>, accessed 17 October 2014.

23 Committee on the Rights of the Child, General Comment no. 16 on State obligations regarding the impact of the business sector on children's rights, UN Doc. CRC/C/GC/16, 17 April 2013, para. 41.

24 Article 2 of the CRC establishes that "States Parties shall respect and ensure the rights set forth in the present Convention to each child within their jurisdiction..." Earlier drafts referred instead to a State's territory, but were revised "in order to cover every possible situation". Office of the High Commissioner for Human Rights, Legislative History of the Convention on the Rights of the Child, Vol. I, United Nations, New York and Geneva, 2007 , p. 333.

25 See the Maastricht Principles on Extraterritorial Obligations of States in the area of Economic, Social and Cultural Rights, Principle 25; Committee on the Rights of the Child, General Comment no. 6 (2005) on treatment of unaccompanied and separated children outside their country of origin, UN Doc. CRC/ GC/2005/6, 1 September 2005, para. 12. 


\section{Private Military and Security Companies}

\section{Box 12}

Companies that provide security and military services (PMSCs) are employed by governments and businesses alike to protect their interests abroad, often in situations of conflict. In the course of their work, PMSCs can pose many risks to children's rights, including the recruitment of children to join security forces and the use of violence against children and communities. As such, governments should take steps to make certain that PMSCs respect children's rights and provide clear legal regulation and accountability for those operating overseas. Notably, Switzerland has passed a law that bans PMSCs from directly taking part in hostilities or providing services to clients likely to be involved in serious human rights violations and abuses. Before engaging PMSCs, Swiss authorities must also review companies' human rights records, policies, training programmes and mechanisms in place to address and remedy infringements. ${ }^{26}$
In some cases, extraterritorial obligations are clearly spelled out in international children's rights provisions or raised in the Committee's Concluding Observations. The OPSC, forinstance, requires States to establish criminal, civil or administrative liability for registered business enterprises and any other legal persons involved in the sale of children, child prostitution or child pornography, wherever in the world these abuses occur. During its periodic reviews, the Committee has also specifically recommended that States take action to address business impacts on children's rights beyond their borders. Among other things, it has called on States to regulate the activities of transnational companies domiciled in their territory, ${ }^{27}$ to provide guidance on children's rights to companies working domestically and transnationally ${ }^{28}$ and to include clauses on children's rights in foreign trade, investment and business agreements. ${ }^{29}$

With this in mind, States should establish clear institutional and legal frameworks to regulate and monitor business activities abroad as they relate to children's rights. Governments that facilitate, support and conduct business overseas, including through State-owned enterprises, must also act in accordance with their children's rights obligations in so doing. has issued specific warnings on the risks that national businesses face in connection with Israeli settlements in the State of Palestine, clearly stating that: "[s] ettlements are illegal under international law... There are therefore clear risks related to economic and financial activities in the settlements, and we do not encourage or offer support to such activity. Financial transactions, investments, purchases, procurements as well as other economic activities (including in services like tourism) in Israeli settlements or benefiting Israeli settlements, entail legal and economic risks stemming from the fact that the Israeli settlements, according to international law, are built on occupied land and are not recognised as a legitimate part of Israel's territory." ${ }^{30}$

26 For the text of the law in French, consult <www.admin.ch/opc/fr/federal-gazette/2013/6577.pdf>, accessed 9 October 2014.

27 Committee on the Rights of the Child, Concluding Observations to Argentina, UN Doc. CRC/C/ARG/CO/3-4, 11 June 2010, paras. 29-30; Concluding Observations to Canada, UN Doc. CRC/C/CAN/CO/3-4, 6 December 2012, para. 29; Concluding Observations to Finland, UN Doc. CRC/C/FIN/CO/4, 20 June 2011, para. 24; Concluding Observations to Guatemala, UN Doc. CRC/C/GTM/CO/3-4, 1 October 2010, paras. $34-35$.

28 Committee on the Rights of the Child, Concluding Observations to Ecuador, UN Doc. CRC/C/ECU/CO/4, 29 January 2010, paras. $30-31$.

29 Committee on the Rights of the Child, Concluding Observations to Nicaragua, UN Doc. CCRC/C/NIC/CO/4, 1 October 2010, para. 30; Concluding Observations to Mozambique, UN Doc. CRC/C/MOZ/CO/2, 29 September 2009, para. 22.

30 UK Trade and Investment, Overseas Business Risk - Israel, 3 December 2013, <http://webarchive.nationalarchives.gov.uk/20140403154217/http:// ukti.gov.uk/gb_gb/uktihome/premiumcontent/107322.html?null>, accessed 3 November 2014 
While primarily economic in nature, trade agreements may have profound impacts on human rights. In bringing new technology, new ways of doing business and unprecedented access to global markets, foreign trade and investment can create significant opportunities for development. Yet, these changes do not guarantee equitable, sustainable and inclusive development, nor do they necessarily promote greater respect for human rights. States, whether acting bilaterally or through multilateral arrangements such as under the World Trade Organization, must take into account their children's rights obligations and should specifically provide for these in trade agreements. As one example, a trade and development agreement between the European Union and a consortium of Caribbean countries requires that the governments involved make certain that new trade arrangements continue to benefit children. ${ }^{31}$

\section{Trade Agreements in Concluding Observations: Ecuador}

"The Committee... recommends that the State party ensure that free trade agreements do not negatively affect the rights of children, inter alia, in terms of access to affordable medicines, including generic ones." 32

\section{Commercial}

\section{Sexual Exploitation}

As implicitly recognized in the OPSC, international travel has created new pathways for the commercial sexual exploitation of children. Governments should establish legal frameworks to make sure that businesses operating in the travel and tourism industry do not contribute to these kinds of children's rights abuses. For example, Italy explicitly prohibits travel agents from promoting trips to exploit children, and requires that tour operators include in itineraries clear references to national laws criminalizing child prostitution and pornography. ${ }^{33}$ Similarly, Honduras has barred promotions, advertisements and publicity campaigns that present the country as a tourist destination for the commercial exploitation of children. ${ }^{34}$

\section{Commercial Sexual Exploitation in Concluding Observations: Thailand}

"The Committee urges the State party to establish and implement an effective regulatory framework and take all necessary legislative, administrative, social and other measures to prevent and eliminate child sex tourism. In this regard, the Committee encourages the State party to strengthen its international cooperation through multilateral, regional and bilateral arrangements for the prevention and elimination of child sex tourism. The Committee further urges the State party to strengthen its advocacy with the tourism industry on the harmful effects of child sex tourism, widely disseminate the Charter of Honour for Tourism and the WTO Global Code of Ethics for Tourism among travel agents and tourism agencies and encourage them to sign up for the Code of Conduct for the Protection of Children from Sexual Exploitation in Travel and Tourism." 35

31 For more information, consult <http://ec.europa.eu/trade/policy/countries-and-regions/regions/caribbean>, accessed 19 October 2014 32 Committee on the Rights of the Child, Concluding Observations to Ecuador, UN Doc. CRC/C/15/Add.262, 13 September 2005, para. 21. 33 Art. 600-quinquies of the Criminal Code, art. 16 of Law no. 269/1998 and art. 25-quinquies of the Legislative Decree no. $231 / 2001$.

34 Arts. 149-E and 5 of the Criminal Code of Honduras, cited in Report of the Special Rapporteur on the sale of children, child prostitution and child pornography, Najat Maalla M'jid - Addendum, Mission to Honduras, UN Doc. A/HRC/22/54/Add.2, 21 January 2013, para. 36.

35 Committee on the Rights of the Child, Concluding Observations to Thailand, UN Doc. CRC/C/OPSC/THA/CO/1, 21 February 2012, para. 24. 


\section{Implementing children's rights obligations}

\subsection{General measures}

The CRC requires States to take "all appropriate legislative, administrative and other measures to effectively implement children's rights." ${ }^{36}$ States must engage all sectors of society, including business enterprises, in the implementation of these measures. It is therefore essential that laws, policies and practices related to business activities are compliant with the Convention and its Optional Protocols, and that the principles and provisions contained therein are applied and enforced with respect to businesses.

Importantly, while the CRC provides that States must implement children's economic, social and cultural rights "to the maximum extent of their available resources", there are minimum essential levels, particularly with respect to the rights to food, housing, health and education, for which States must achieve immediate, not progressive, realization. ${ }^{37}$ States must always maintain these levels, seeking international cooperation and assistance where necessary and paying special attention to the most vulnerable and disadvantaged groups. ${ }^{38}$ In addition, the Committee on the Rights of the Child has observed that the "[e]njoyment of economic, social and cultural rights is inextricably intertwined with enjoyment of civil and political rights". ${ }^{39}$

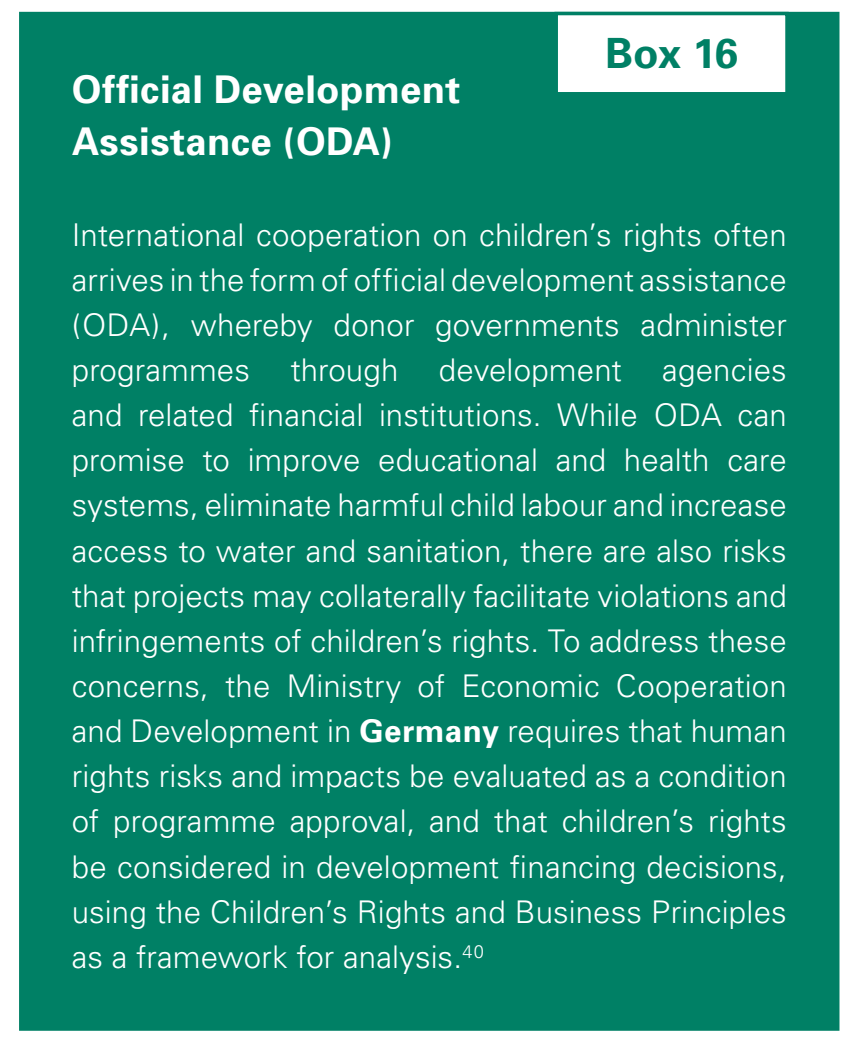

\subsection{Governance and administrative structures}

"It is important to recall that the Convention and the Optional Protocols thereto engage the State as a whole, regardless of its internal structures, branches or organization. Furthermore, decentralization of power, through devolution and delegation, does not reduce the direct responsibility of the State to meet its obligations to all children within its jurisdiction."

- General Comment no. 16, para. 10

Implementing the CRC, OPAC and OPSC must involve all levels of government, which can raise challenges given the diverse array of national governance and administrative structures. Some States have a federal or decentralized system of governance, for instance, with regional and local authorities enjoying ample powers. These structures often result in laws and policies that vary across the country, and may for this reason pose difficulties in developing a comprehensive and coherent national agenda.

Importantly, the Convention and its Optional Protocols bind States as a whole, regardless of their internal divisions and structures. In federal or decentralized States, then, meeting children's rights will require action by local and regional authorities in addition to the central government. Accordingly, GC 16 recommends that central governments put adequate control mechanisms in place to ensure that children's rights obligations with respect to business activities are clearly communicated and implemented at all levels of government in every locality within a State.

36 See CRC, art. 4, which states that: "States Parties shall undertake all appropriate legislative, administrative, and other measures for the implementation of the rights recognized in the present Convention. With regard to economic, social and cultural rights, States Parties shall undertake such measures to the maximum extent of their available resources and, where needed, within the framework of international co-operation."

37 Committee on Economic, Social and Cultural Rights, General Comment No. 3: The nature of States parties'obligations (art. 2, para.1, of the Covenant), UN Doc. E/1991/23, paras. 9 and 10

38 Ibid., paras. 10, 12, 13.

39 Committee on the Rights of the Child, General Comment no. 5, General Measures of implementation of the Convention on the Rights of the Child (arts. 4, 42, and 44, para. 6), UN Doc. CRC/GC/2003/5, 27 November 2003, para. 6.

40 International Commission of Jurists, Financial Institutions and the Rights of the Child, An overview of Policies and Accountability Mechanisms, ICJ, Geneva, 2014, pp. 46-47. 
In addition, States often exercise powers and functions relevant to children's rights and business enterprises through a variety of ministries, agencies, departments and other administrative bodies, as well as through judicial authorities. Each of these may be responsible for making decisions on a defined subject matter, and often agencies entrusted with regulating and monitoring business-related issues operate separately from those tasked with looking after children's rights. No matter how administrative divisions or judiciaries are organized, governments must make sure they act in a coordinated fashion to respect, protect and fulfil children's rights.

\subsection{Legal systems}

"States parties need to ensure, by all appropriate means, that the provisions of the Convention are given legal effect within their domestic legal systems."

-General Comment No. 5, para. 19

States implement the CRC, OPAC and OPSC in line with their legal and cultural systems, including civil law, common law, religious law, customary law and mixed or plural legal systems. These present different challenges and opportunities for meeting children's rights obligations, including with respect to business enterprises. Religious laws, for example, may be more open to new interpretations than to formal change, and plural legal systems often set out different laws for different sectors of society in ways that make for a complicated patchwork of rules and regulations. Approaches to incorporating international law also vary across legal systems, with civil law countries tending to give treaty obligations direct effect in national law and common law countries more often requiring specific legislation to incorporate ratified treaties into the national legal order.

Despite these differences, children's rights remain the same and States have the same obligations to realize them, no matter what their legal system. Indeed, it is core principle of international law that a State cannot use its domestic arrangements to justify its failure to meet an international obligation. ${ }^{41}$ As such, the Committee on the Rights of the Child has favoured the incorporation of the CRC into national law so that it is given precedence over potentially conflicting legislation and is enforceable in domestic courts against any party that has violated or threatens to violate children's rights. ${ }^{42}$ Similarly, the Committee has emphasized that Convention rights should be recognized as equal and indivisible irrespective of the national legal tradition, with no distinctions made between civil and political and economic, social and cultural rights. ${ }^{43}$

To achieve this, the Committee advises full and direct incorporation of the Convention in a single, comprehensive national law to clearly establish core rights applicable to all children within a State's jurisdiction. ${ }^{44}$ In more complex legal systems, States might also need to grant the CRC constitutional recognition or establish a separate bill of rights to ensure sufficient authority. Once an overarching legal framework for children's rights has been established, this can serve as a basis for wide-reaching harmonization of existing legislation, regulations, policies and practices, including those that govern how business is conducted. This process should necessarily involve a review of domestic courts and other remedial mechanisms, as every justice system should empower child victims of rights violations or infringements and their representatives to seek accountability and redress from any party, including both governments and businesses that may be wholly or partly responsible for an abuse or violation.

41 Committee on the Rights of the Child, General Comment no. 16 on State obligations regarding the impact of the business sector on children's rights, UN Doc. CRC/C/GC/16, 17 April 2013, para. 10.

42 "The Committee welcomes the incorporation of the Convention into domestic law, which is the traditional approach to the implementation of international human rights instruments in some but not all States. Incorporation should mean that the provisions of the Convention can be directly invoked before the courts and applied by national authorities and that the Convention will prevail where there is a conflict with domestic legislation or common practice. Incorporation by itself does not avoid the need to ensure that all relevant domestic law, including any local or customary law, is brought into compliance with the Convention. In case of any conflict in legislation, predominance should always be given to the Convention, in the light of article 27 of the Vienna Convention on the Law of Treaties." Committee on the Rights of the Child, General Comment no. 5, General measures of implementation of the Convention on the Rights of the Child (arts. 4, 42, and 44, para. 6), UN Doc. CRC/GC/2003/5, 27 November 2003 , para. 20. 43 Ibid., para. 25

44 See United Nations Children's Fund, Protecting the World's Children, Impact on the Convention on the Rights of the Child in Diverse Legal Systems, 2007, p. 7; Rishmawi, Mervat, 'Article 4: the Nature of States Parties' Obligations', 2006, p. 25, recalling CRC Concluding Observations that recommend States incorporate the Convention in one single piece of legislation. However, the author also refers to a later approach taken by the Committee advising States to ensure all relevant sectoral laws are compliant with the principles of the CRC. 


\title{
STRATEGIES AND TOOLS TO REGULATE AND INFLUENCE BUSINESS
}

\section{Developing Strategies and Tools to Regulate and Influence Business}

\author{
"It is necessary for States to have adequate legal and institutional frameworks to respect, protect and fulfil children's rights, and \\ to provide remedies in case of violations in the context of business activities and operations." \\ -General comment no. 16, para. 4
}

To meet their children's rights obligations under the CRC, OPAC and OPSC, States must develop strong, comprehensive and holistic strategies to ensure that businesses respect children's rights as detailed in GC 16. Putting these strategies into action can draw from and employ an array of tools, from broad to targeted laws, policies, public campaigns and awareness-raising. When developing plans and implementing actions to address children's rights and business, States should consult with civil society organizations, academics, independent experts, businesses and affected communities and individuals, and, most importantly, take special measures to facilitate the meaningful participation of children.

"States should hear children's views regularly... when developing national and local-level business-related laws and policies that may affect them. In particular, States should consult with children who face difficulties in making themselves heard, such as the children of minority and indigenous groups, children with disabilities... and children in similar situations of vulnerability."

-General comment no. 16, para. 21

School councils, children's organizations and associations, youth parliaments and social media groups can serve as useful entry points, and particular efforts should also be made to reach the most vulnerable and marginalized children who may not otherwise have a voice in the political process.

\section{Consulting Stakeholders}

To develop a new national policy promoting healthy diets, Norway ran extensive public consultations with a large and diverse range of individuals, including children. Participants were asked to share their preferences and ideas on the content of healthy diets, and to suggest measures that the government could take to promote these. Recommendations from the consultation were published and presented to high-level officials in open, interactive meetings. 45 


\section{Legislation and regulation}

"Legislation and regulation are essential instruments for ensuring that the activities and operations of business enterprises do not adversely impact on or violate the rights of the child. States should enact legislation that gives effect to the rights of the child by third parties and provides a clear and predictable legal and regulatory environment which enables business enterprises to respect children's rights." - General Comment no. 16, para. 53

States must legislate and administratively regulate to ensure that business activities, operations and relationships are consistent with the CRC, OPAC and OPSC. To this end, governments should strive to create clear, predictable legal frameworks that make corporate respect for children's rights both expected and feasible. Laws should be targeted to address specific issues of relevance, and at the same time create overall enabling environments so that businesses appreciate the ways in which they need to consider children's rights in their work.

As a first step, governments should conduct a comprehensive review to understand the extent to which their existing laws and policies address business and children's rights. This review should seek to cover all aspects that directly or indirectly shape how business activities and operations impact children's rights, and where gaps are evident, governments should take action to bring their laws in line with international standards. In so doing, it is important for governments to identify the agencies, ministries and departments whose work touches on issues related to business and children's rights, and to ensure that mechanisms for effective inter-agency cooperation are in place. Notably, some of these bodies may have regulatory and enforcement powers in areas of law such as labour, environment, or consumer protection that have a direct bearing on children's rights.

\section{Legal Frameworks in Concluding Observations: Morocco}

Box 18

"The Committee draws the State party's attention to its General Comment no. 16 (2013) on State obligations regarding the impact of the business sector on children's rights and especially recommends that the State party:

(a) Examine and adapt its legislative framework concerning legal accountability of business enterprises and their subsidiaries operating in or managed from the State party's territory, especially in the tourism industry". 46

GC 16 further identifies certain subject areas and economic sectors that may merit greater levels of attention as they pose specific risks to the enjoyment of children's rights. Among other areas of concern, these include parental working conditions that impact on child development; intellectual property rights that affect access to medicine; and digital media that create potential avenues for child sexual exploitation. A number of these topics are explored in further detail in the examples of national practice that appear throughout this guide.

GC 16 also indicates that States should adopt legal measures of more general applicability to children's rights and business. First and foremost, governments should introduce regular impact assessments for all business-related laws that could impact on children's rights. Similarly, governments should require that companies examine their actual and potential impacts on children's rights through what is known as the due diligence process. Additionally, both of these undertakings should be accompanied by reporting and disclosure requirements that foster transparency and informed public dialogue. 
"Ensuring that the best interests of the child are a primary consideration in business-related legislation and policy development and delivery at all levels of government demands continuous child-rights impact assessments. These can predict the impact of any proposed business-related policy, legislation, regulations, budget or other administrative decisions which affect children and the enjoyment of their rights and should complement ongoing monitoring and evaluation of the impact of laws, policies and programmes on children's rights." -General Comment no. 16, para. 78

Child rights impact assessments (CRIAs) provide a way for governments to understand whether and how their actions will affect children. CRIAs should be initially performed whenever governments propose new business-related laws, policies or administrative measures with a bearing on children's rights obligations, and should be revisited continually to monitor and evaluate the impacts of decisions and actions. They should look not only at potential impacts on children as a whole, but also at impacts on specific groups of children who may be differentially affected. ${ }^{47}$

On a practical level, States may already require that impact assessments be performed either more broadly for human rights or more specifically for individual sectors of the economy or discrete issues of concern. Where this is the case, governments should embed children's rights considerations within established impact assessment models. Regardless of the approach, CRIAs should always be grounded in the CRC, OPAC and OPSC and follow a logical, consistent process.

\section{CRIAs in Concluding Observations: Thailand}

" $[T]$ he Committee recommends that the State party... (b) Promote the inclusion of child rights indicators and parameters for reporting and provide specific assessments of impacts of business and industry on child rights...". 48

\section{Performing a CRIA}

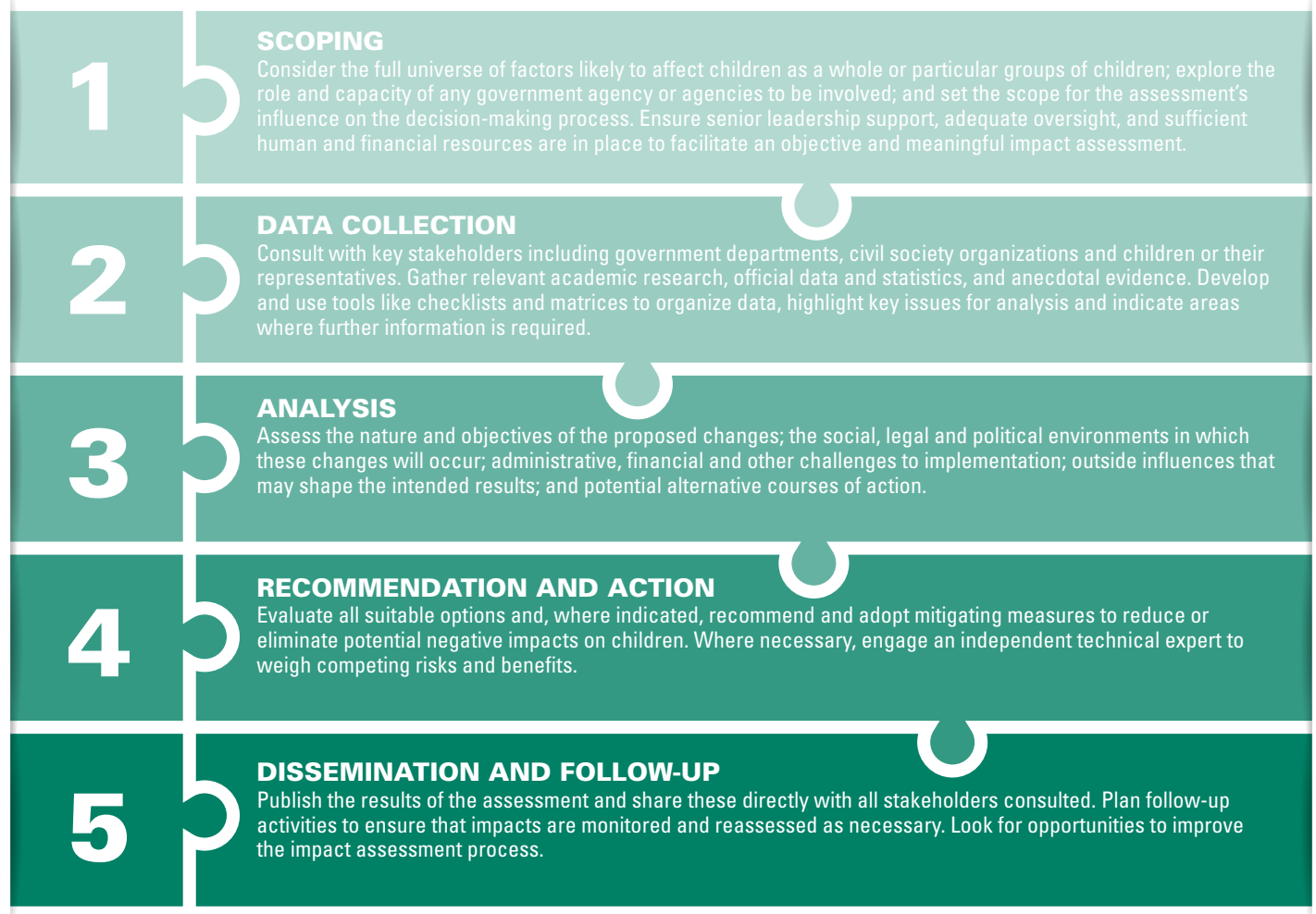

47 In determining whether specific groups of children are more likely to be differentially impacted by a law, policy or administrative measure, consideration should be given to issues of gender; vulnerability or marginalization; indigenous peoples; national, ethnic or linguistic minorities; children with disabilities; and children of migrant workers. See UNICEF Canada, Child Rights Impact Assessment: A Tool to Focus on Children, 2013, p. 3; EU, UNICEF, Child Rights Toolkit: Integrating Child Rights in Development Cooperation, Module 5: Child Impact Assessments, 2014 p. 18.

48 Committee on the Rights of the Child, Concluding Observations to Thailand, UN Doc. CRC/C/THA/CO/3-4, 17 February 2012, para. 30. 
CRIAs in Practice

The regional government of Flanders in Belgium requires that Child and Youth Impact Assessments be attached to all proposed laws likely to have a direct impact on the interests of people under age 25 . At a minimum, these must contain descriptions of the likely effects on children and young people if the law is or is not adopted, and contemplate measures that could be taken to prevent, mitigate and remedy any resulting negative impacts. The Government has also published a manual to guide the preparation of Child and Youth Impact Assessments, which is integrated into a larger human rights impact assessment process. ${ }^{49}$

The regional government of Wales in the United Kingdom requires that high-level officials carry out Child Rights Impact Assessments when making certain decisions or proposing legal measures that are relevant to children and young people. All CRIAs follow an established template, and a special advisory group is available to help staff determine whether an impact assessment should be undertaken. Final results are published on completion for legal measures, and made available upon request for other administrative decisions. ${ }^{50}$

The national strategy for implementing the CRC in Sweden calls on the government to undertake Child Impact Assessments for all public decisions that affect children. The Swedish Children's Ombudsperson has developed a model for conducting impact assessments, which has been followed by a number of government authorities including the National Board of Housing, Building and Planning and the Swedish International Development and Cooperation Agency. ${ }^{51}$

49 Decree on a renewed youth and children's rights policy of the Flemish government of 20 January 2012, art. 6. For an evaluation of JOKER consult $<w w w . g o o g l e . c h / u r l ? s a=t \& r c t=j \& q=\& e s r c=s \&$ source $=w e b \& c d=1 \& c a d=r j a \& u a c t=8 \& v e d=0 C C I Q F j A A \& u r l=h t t p \% 3 A \% 2 F \% 2 F w w w . k e k i . b e \% 2$ Fdocuments\%2F2012 11 15\%2520joker\%2520evaluation_executive\%2520summary.docx\&ei=5d47VLLVBcL2aJTEgKgH\&usg=AFQjCNEhOwOn paYM4NWAS6AKAmWsjtPzPg\&bvm =bv.77161500,d.bGQ>, accessed 13 October 2014.

50 Welsh government, Children's Rights Scheme 2014, <http://wales.gov.uk/docs/dsjlg/publications/cyp/140501-childrens-rights-scheme-2014-en. pdf $>$, accessed 13 October 2014.

51 For the Child Impact Assessment model, consult <www.manskligarattigheter.se/dm3/file_archive/020523/d18c33283b29d7cbb15d9bb65d1db726/ barn\%20Child\%20Impact\%20Assessments.pdf>, accessed 13 October 2014 


\subsection{Child rights due diligence}

"To meet their obligation to adopt measures to ensure that business enterprises respect children's rights, States should require business to undertake child-rights due diligence. This will ensure that business enterprises identify, prevent and mitigate their impact on children's rights including across their business relationships and within global operations."

-General Comment no. 16, para. 62

Just as States should conduct child rights impact assessments with respect to laws, policies and other important public initiatives, businesses should likewise be required to undertake child rights due diligence to understand the ways in which their activities, operations and relationships affect children's rights. Drawing from the UNGPs, child rights due diligence can be described as an ongoing process whereby businesses are asked to identify and assess actual and potential child rights impacts; to integrate and act upon relevant findings; to track the adequacy and effectiveness of their responses; and to openly communicate how impacts have been addressed. ${ }^{52}$ Through this process, businesses can not only learn how to prevent, mitigate and account for negative impacts on children, but also seek out opportunities to advance children's rights. ${ }^{53}$

As with CRIAs, child rights due diligence can be subsumed within a more general process of human rights due diligence, provided that the rights of children as a whole as well as certain groups of children more likely to be affected are given specific attention throughout the process. States should require that all businesses undertake some form of child rights due diligence and effectively act upon the outcomes of these processes.

Governments may also use other levers to ensure greater uptake of due diligence. For instance, they can require businesses to submit evidence of due diligence processes when bidding for a public contract, requesting public financing or applying to be listed on the stock exchange. To assist small and medium sized enterprises in meeting their obligations, governments can provide training and give targeted guidance on relevant requirements and processes. Furthermore, state-owned companies can publish the complete results of their due diligence efforts to inspire and set higher standards for all companies. In circumstances where business operations pose a high risk of serious negative impacts to children's rights, whether due to the nature of the business or to the context in which it is operating, governments should take a more active role in setting and monitoring adherence to a stricter due diligence process.

\section{Public Procurement}

\section{Box 21}

Many governments purchase large quantities of goods and services from the private sector, and public procurement rules set out the methods and processes by which they acquire them. Public procurement rules should establish frameworks and expectations for entering into business relationships with third parties, and make certain that government contractors do not infringe children's rights by, for instance, using forced or child labour. As one example, the United States government prohibits contractors and subcontractors from supporting or engaging in human trafficking. For projects of a certain size, the government also requires that contracting businesses prepare compliance plans detailing due diligence procedures to assess, prevent, mitigate and remediate any suspected involvement. $^{54}$
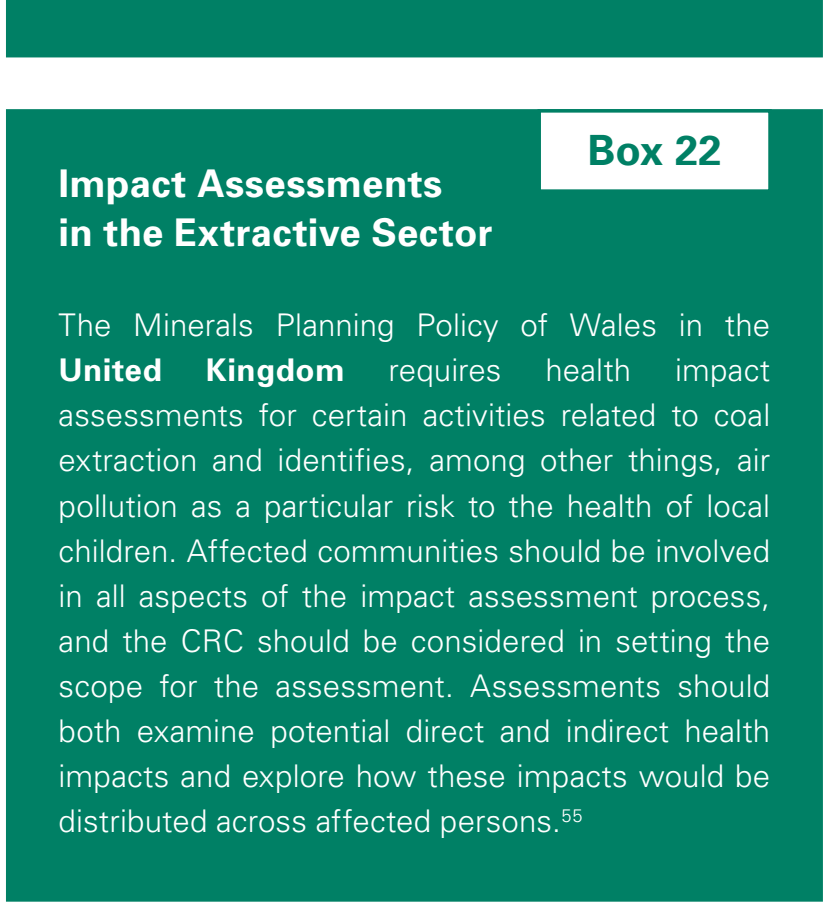

52 See UNGPs, Principles 17 and 21

53 See CRPBs no. 1.

54 United States of America, Executive Order - Strengthening Protection against Trafficking in Persons in Federal Contracts, 25 September $2012,<$ www. whitehouse.gov/the-press-office/2012/09/25/executive-order-strengthening-protections-against-trafficking-persons-fe>, accessed 22 October 2014.

55 Welsh government, Minerals Technical Advice Note 2: Coal (2009), <http://wales.gov.uk/docs/desh/policy/090120coalmtanen.pdf>, accessed 14 January 2015. 


\section{Human Rights Due Diligence on the Horizon}

Following Switzerland's 2014 release of a comparative research study on human rights due diligence in national law, the parliament narrowly rejected a legislative proposal requiring business enterprises to undertake and publicly report on human rights due diligence. ${ }^{56}$ In response, supporters of the proposal have called a popular referendum on the initiative. ${ }^{57}$ Similarly, draft legislation in France revised and reintroduced in 2015 would require that certain corporations adopt monitoring plans to address the risks of potential human rights infringements in their operations and those of their subsidiaries, while also creating legal liability for the failure to do so. ${ }^{58}$ Meanwhile, the Superintendency of Banks, Insurance, Companies and Pension Funds in Peru has prepared new regulations for the financing of mining and other large projects that require, among other things, borrowers to provide information about consultations with affected communities and develop plans to measure, mitigate and remedy any negative impacts. ${ }^{59}$

\section{Child Rights Due Diligence for Business ${ }^{60}$}

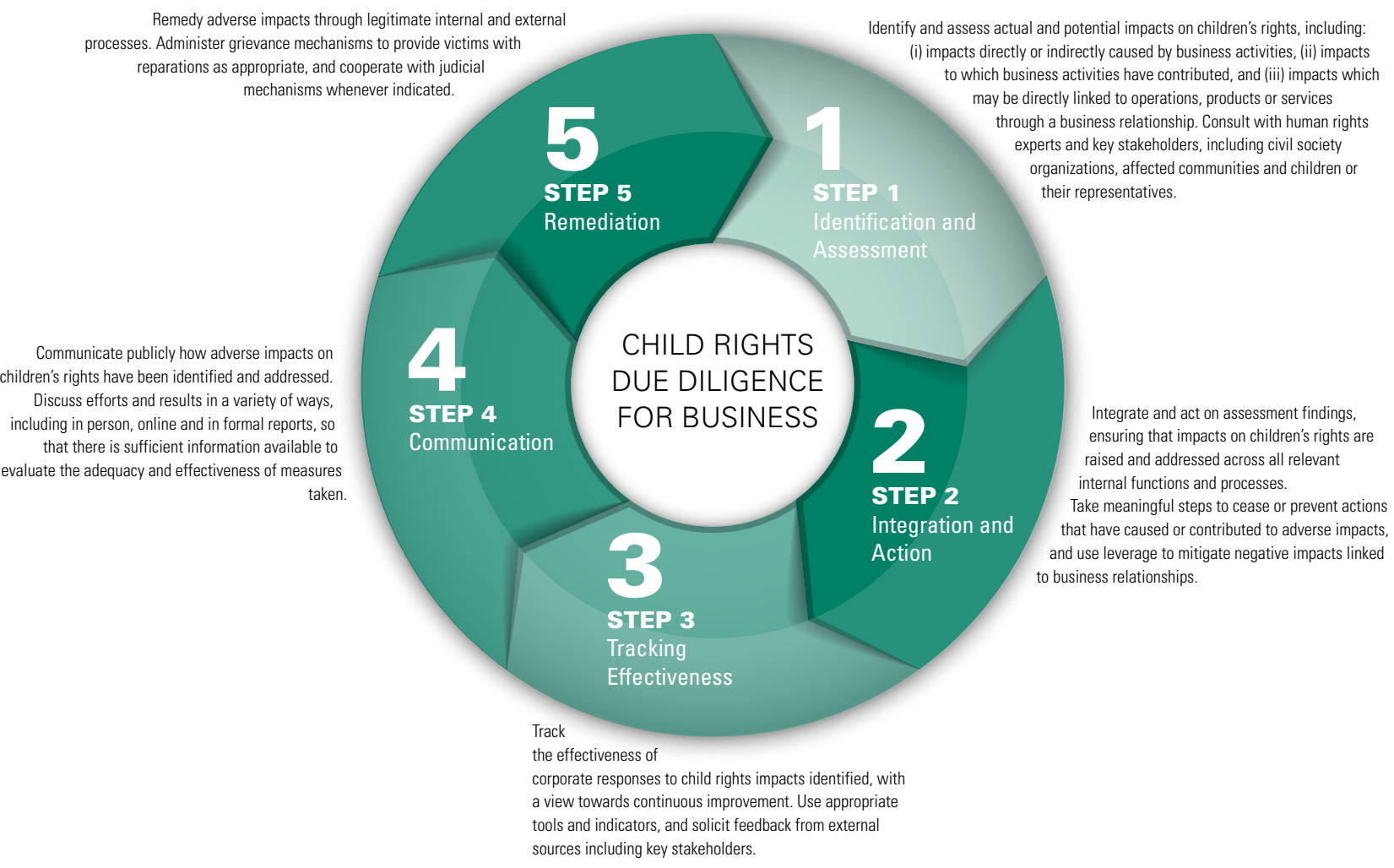

56 For the text of the motion in French consult <www.parlament.ch/e/suche/Pages/geschaefte.aspx?gesch_id=20143671>, accessed 21 October 2014. 57 See Swiss Campaign for Corporate Justice, Global Business? Global Responsibility, 20 April 2015, <www.corporatejustice.ch/en/>, accessed 24 April 2015

58 France, Assemblée Nationale, N²578 - Proposition de loi relative au devoir de vigilance des sociétés mères et des entreprises donneuses d'ordre, Enregistré à la Présidence de l'Assemblée nationale, 11 February 2015, <www.assemblee-nationale.fr/14/propositions/pion2578.asp>, accessed 18 March 2015; see also Association Sherpa, Deuxième proposition de loi sur le devoir de vigilance des multinationales : peu d'évolutions après l'examen en commissions, 11 March 2015, <www.asso-sherpa.org/deuxieme-proposition-loi-sur-le-devoir-de-vigilance-des-multinationales-peu-devolutionsapres-lexamen-en-commissions/\#.VQnMw2SsWY2>, accessed 18 March 2015.

59 Schydlowsky, Daniel M. and Robert C. Thompson, Reducing the Financial Risk of Social Conflict, in Americas Quarterly, Spring 2014, <www. americasquarterly.org/content/reducing-financial-risk-social-conflict>, accessed 23 October 2014; Uptake of the Guiding Principles on Business and Human Rights: practices and results from pilot surveys of Governments and corporations, Addendum to the Report of the Working Group on the issue of human rights and transnational corporations and other business enterprise, UN Doc. A/HRC/23/32/Add.2, 16 April 2013, para. 46.

60 See UNGPs, Principles 18-21; CRBPs, Principles 1, 8, 9. 
"[L]arge business enterprises should be encouraged and, where appropriate, required to make public their efforts to address child-rights impacts. Such communication should be available, efficient and comparable across enterprises and address measures taken by business to mitigate potential and actual adverse impacts for children caused by their activities."

-General Comment no. 16, para. 65

\section{Child Rights \\ Reporting in Concluding Observations: Denmark}

"The Committee recommends that the State party provide a framework for reporting on child rights by Danish corporations, including multinational corporations headquartered in Denmark, and for the National Contact Point to address cases of non-compliance, including extraterritorially, by Danish multinational enterprises. In so doing, the Committee recommends that the State party apply the relevant provisions of the Convention. The Committee further encourages the State party to give due consideration to experiences from around the world in the application of, inter alia, the United Nations 'Protect, Respect and Remedy' Framework to the operations of private and public corporations, particularly in respect to child rights." 61
To complement child rights due diligence, governments should mandate that businesses publish reports to explain how they assess, consider and incorporate children's rights impacts across their activities, operations and relationships. Reporting sheds light on businesses' compliance with due diligence obligations; enables direct comparisons between companies and industries; offers assurances that proper risk-management procedures are in place; and can prompt governments to investigate and remedy adverse impacts. As such, clear expectations should be placed on companies to publicly disclose relevant information at regular intervals.

Reporting requirements may vary based on the size and nature of business operations, with higher levels of disclosure expected from larger or transnational enterprises. Information about children's rights might be incorporated into existing non-financial reporting requirements, so long as children's rights are featured holistically and distinctly in analyses and discussions. In all cases, governments should ensure effective monitoring of the accuracy and quality of information submitted, and consider assigning primary oversight responsibility to a regulatory body with the authority and resources to request the independent verification of reports and issue sanctions for non-compliance. To facilitate greater transparency, governments may also wish to provide instructive models, templates and tools; establish performance benchmarks and best practices; and officially recognize exemplary reports. 


\section{Reporting Obligations in Practice}

\section{Box 25}

Sweden requires all public sector enterprises to prepare sustainability reports in line with the Global Reporting Initiative (GRI) framework, including information related to human rights, diversity, working conditions, the environment and corruption. ${ }^{62}$

Denmark requires all large national companies to publicly report on, among other things, climate change and human rights-related policies, actions undertaken in furtherance of these policies, and outcomes of these actions. While companies are not strictly required to adopt human rights policies, they must expressly disclose where these are not in place. ${ }^{63}$

In the United States, the state of California's Transparency in Supply Chains Act mandates that companies doing business in the state publicize their efforts to fight human trafficking and slavery across their global operations. This includes information relating to risk assessments, audits, supplier requirements, training programmes and accountability measures. ${ }^{64}$

The European Union has adopted a directive requiring non-financial disclosure by large companies, including information related to business impacts on labour, the environment, human rights, corruption and bribery. Notably, the directive grants reporting businesses significant flexibility in determining the form and manner of disclosure. ${ }^{65}$

62 Corporate Social Responsibility in Sweden, <https://sweden.se/business/csr-in-sweden>, accessed 16 October 2014.

63 Danish Business Authority, Legislation, < http://csrgov.dk/legislation>, accessed 22 October 2014.

64 United States of America, California Transparency in Supply Chains Act, Civil Code, para. 1714.43 (2012), <www.leginfo.ca.gov/cgi-bin/displaycode? section $=$ civ\&group =01001-02000\&file=1708-1725>, accessed 3 November 2014, cited in De Schutter, Olivier et al., Human Rights Due Diligence. The Role of States - Examples, International Corporate Accountability Roundtable, p. 129, <http://hrdd.accountabilityroundtable.org/sites/default/ files/Human\%20Rights\%20Due\%20Diligence\%20-Examples-.pdf>, accessed 21 October 2014.

65 European Commission, Disclosure of non-financial information: Europe's largest companies to be more transparent on social and environmental issues, Statement/14/291, 29 September 2014, <http://europa.eu/rapid/press-release_STATEMENT-14-291_en.htm>, accessed 23 October 2014. 


\section{Voluntary Initiatives}

“The Committee acknowledges that voluntary actions of corporate responsibility by business enterprises, such as social investments, advocacy and public policy engagement, voluntary codes of conduct, philanthropy and other collective actions, can advance children's rights. States should encourage such voluntary actions and initiatives as a means to create a business culture which respects and supports children's rights. However, it should be emphasized that such voluntary actions and initiatives are not a substitute for State action and regulation of business in line with obligations under the Convention and its protocols or for businesses to comply with their responsibilities to respect children's rights." -General Comment No. 16, para. 9

While not carrying the force of hard law, businessled self-regulation schemes, industry guidelines, codes of conduct and other voluntary corporate social responsibility initiatives can all implement and even set new standards for children's rights. Where these represent genuine efforts to advance respect for children's rights, governments can consider participating in, supporting or overseeing their development. Codes of conduct with particular importance for children's rights include, for example, the International Code of Marketing of Breast-milk Substitutes ${ }^{66}$ and the Code of Conduct for the Protection of Children from Sexual Exploitation in Travel and Tourism. ${ }^{67}$

Governments can help shape voluntary standards to set clear expectations for the conduct of business enterprises, establish performance benchmarks, and introduce reporting or monitoring mechanisms. Once published, they can likewise promote these initiatives and actively encourage businesses to adhere to child rights standards. It must be remembered, however, that voluntary standards and self-regulation schemes are not a substitute for legislation and regulation. States must in any event maintain or develop an effective legal framework to ensure full realization of children's rights.

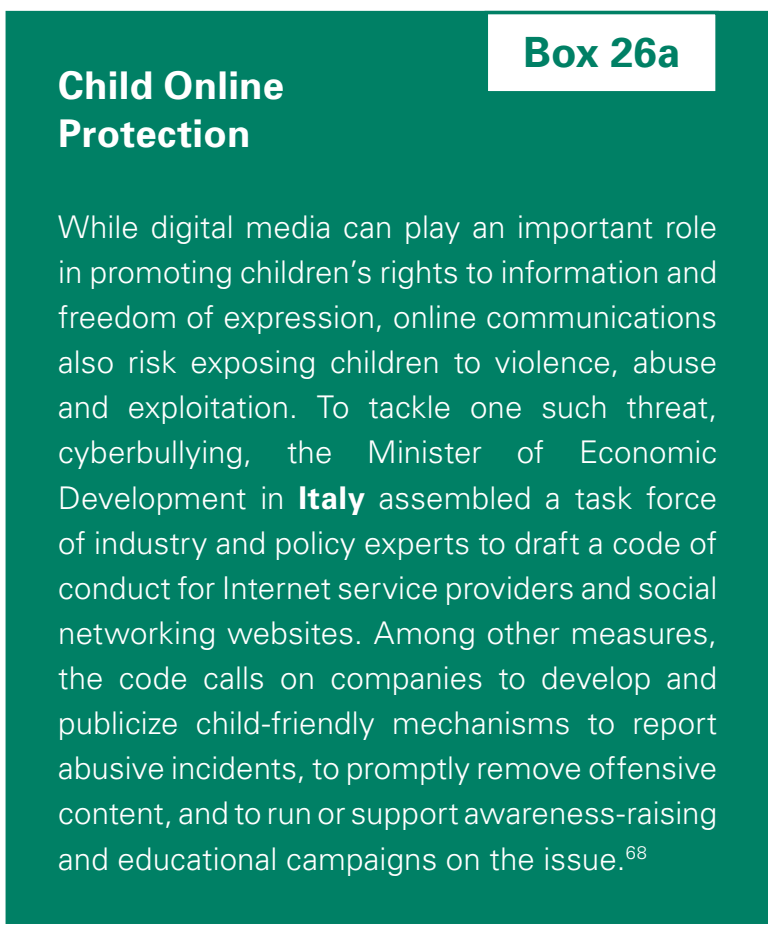

Voluntary

Box 26b

\section{Observations: Panama}

Concluding

"The Committee is concerned with the role the media and advertising industries play in reinforcing gender-based prejudice and discrimination... The Committee recommends that the State party... [b]earing in mind the right to freedom of expression, promote the adoption of voluntary codes of conduct, especially regarding the rights of children to privacy, to have access to appropriate information and to express their views..."69

66 WHO, The International Code of Marketing of Breast-milk Substitutes, World Health Organization, Geneva, 1981, <www.who.int/nutrition/publications/ code_english.pdf >, accessed 23 October 2014.

67 For more information on the Code, consult <www.thecode.org $>$, accessed 23 October 2014

68 For the text of the Draft Code in Italian, consult $<w w w$. sviluppoeconomico.gov.it/index.php?option=com_content\&view $=$ article \&viewType $=1 \&$ idar

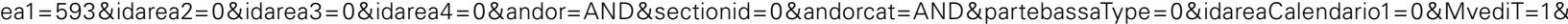
showMenu=1\&showCat=1\&showArchiveNewsBotton=0\&idmenu=2263\&id=2029886>, accessed 16 October 2014.

69 Committee on the Rights of the Child, Concluding Observations to Panama, UN Doc. CRC/C/PAN/CO/3-4, 21 December 2011, paras. 29-30. 


\title{
2. Policy, planning and programmes
}

\begin{abstract}
"States should include the issue of children's rights and business in the overall context of the national policy frameworkforimplementation of the Convention. They should develop guidance that explicitly sets out government expectations for business enterprises to respect children's rights in the context of its own business activities, as well as within business relationships linked to operations, products or services and activities abroad when they operate transnationally."-General Comment no. 16, para. 73
\end{abstract}

States have for many years been encouraged by United Nations authorities to develop comprehensive national strategies to realize international children's rights. $^{70}$ These strategies represent overarching public policy commitments to implement the CRC, OPAC and OPSC across all territorial and administrative divisions, uniting relevant plans and initiatives in a single, inclusive, rightsbased agenda as a stand-alone document part of a broader human rights strategy. GC 16 emphasizes the need for national children's rights policy frameworks to incorporate business-related issues, and recognizes that all relevant government policies must direct the private sector to

Informal Economy

Box 27

Because businesses operating in the informal economy work outside the sphere of government regulation and monitoring, they often do not respect national or international human rights standards and may place children and their caregivers at heightened risk of exploitation. Governments should not only work to understand and monitor informal economic activity, but also seek to bring unregistered or unauthorized businesses into legal operating frameworks wherever possible. In the Philippines, for example, the government has adopted a range of measures to help unauthorized water service providers enter the formal economy, including lowered registration fees, assistance with permit applications, and training on tariff structures. ${ }^{71}$

fulfil their responsibilities to respect children's rights.

National strategies must do more than simply express good intentions or make broad political statements. Effective plans not only set out clear, attainable goals in the short, medium and long terms, but also describe practical ways to achieve these goals. In so doing, these plans designate concrete targets and milestones, assign management responsibility, and allocate necessary financial and human resources. Strategies should be endorsed by the highest levels of government, and mechanisms should be put in place to monitor results and re-evaluate plans as necessary.

\section{Fostering a Culture of Respect for Human Rights}

\section{Box 28}

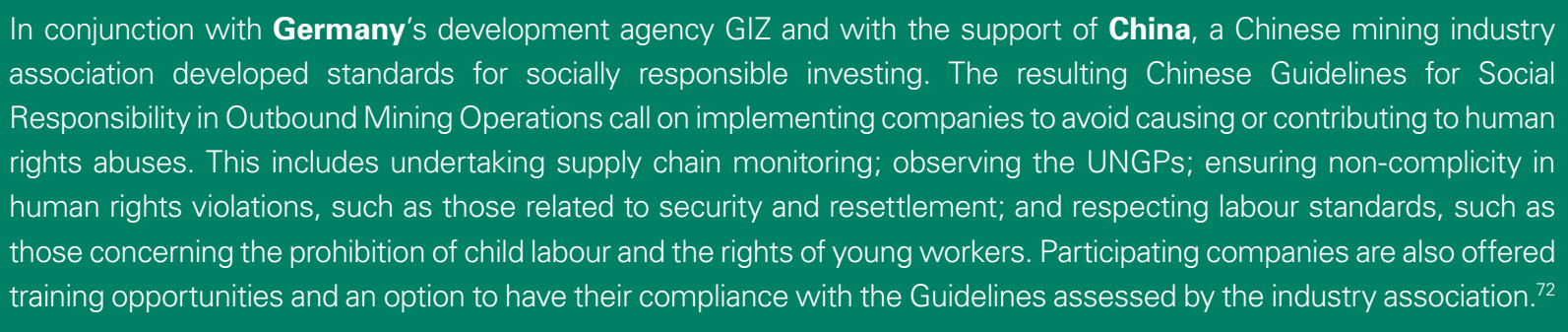

The Industrial Development Agency in Poland runs a programme to promote socially responsible entrepreneurship. The Agency also supports small and medium-sized enterprises to implement corporate social responsibility standards across their operations and activities, and provides funding to civil society organizations to deliver training on related subjects.

70 In 1990, States were encouraged to set out National Plans of Action for the implementation of the Convention during the first World Summit for Children. In the 2002 United Nations General Assembly Special Session on Children, States committed to developing or strengthening national and/or regional action plans with specific and measurable goals, targets and timelines. In 2003, the Committee again highlighted the need for governments to adopt comprehensive implementation strategies for the Convention. Committee on the Rights of the Child, General Comment no. 5, General measures of implementation of the Convention on the rights of the Child (arts. 4, 42, 44, para. 6), UN Doc. CRC/GC/2003/5, 27 November 2003, paras. 28-35.

71 UNICEF East Asia and Pacific Regional Office, ADB, The Role of Non-State Providers in Delivering Basic Social Services for Children - Workshop Report, 2010, p. 30, <WWW.unicef.org/eapro/NSP_Workshop_ReportJuly_14_FINAL.pdf>, accessed 22 October 2014.

72 China Chamber of Commerce of Metals, Minerals \& Chemicals Importers and Exporters, Guidelines for Social Responsibility in Outbound Mining Investment, <www.globalwitness.org/sites/default/files/library/CCCMC\%20Guidelines\%20for\%20Social\%20Resposibility\%20in\%200utbound\%20 Mining\%20Investments\%200ct\%202014\%20CH-EN.pdf>, p. 34, accessed 21 January 2015. See also, Global Witness, New Chinese Guidelines offer mineral companies chance to reduce conflict, corruption risks and show value to host communities, 24 October 2014, <www.globalwitness.org/library/ new-chinese-guidelines-offer-mineral-companies-chance-reduce-conflict-corruption-risks-and-0>, accessed 5 January 2015.

73 Polish Agency for Enterprise Development, Swiss-Polish Cooperation Programme, <http://en.parp.gov.pl/index/index/2016>, accessed 18 October 2014; Council of Europe, Corporate social responsibility in the field of human rights - Proposals and suggestions of issues for further consideration (updated version, June 2014 (CDDH-CORP(2014)007add.), <www.coe.int/t/dghl/standardsetting/hrpolicy/other_committees/hr_and_business/ Documents/CDDH-CORP(2014)007add_en\%20(2).pdf>, accessed 18 October 2014, p. 15. 
“When States develop national strategies and plans of action for implementation of the Convention and the Optional Protocols thereto, they should include explicit reference to the measures required to respect, protect and fulfil children's rights in the actions and operations of business enterprises. States should also ensure that they monitor progress in implementation of the Convention in the activities and operations of business."

-General Comment no. 16, para. 77

As stated above, States should introduce business-related issues into their national strategies to implement the CRC. To begin this process, governments should launch internal and external consultations that help set the scope, priorities, and areas of responsibility for revision. All ministries, agencies, departments and other governmental authorities with mandates that relate to children's rights and business should be informed, and a focal point or points for coordination should be identified. Revision might be managed by one or more key actors or, preferably, be overseen by an inter ministerial committee established for these purposes, and public consultations with stakeholders and rights holders should be held early on, making sure that children have an opportunity to share their views. Taken together with agency input, this information should be used to map areas of concern and identify policy gaps.

The revision process should be designed to bring the plan in line with the obligations elaborated in GC 16 and follow recommendations on children's rights and business issued in the Committee on the Rights of the Child's Concluding Observations. The new plan should establish government expectations for businesses to respect children's rights, covering both domestic and international operations and extending into business networks and relationships. Particular attention should be given to the rights of children in difficult situations that indicate a need for special protection measures. The plan or strategy should also take into account and link with other planning processes, noting any sector level policies like those for health or education that will require amendment. Where indicated, financial and human resources should then be increased or reallocated to provide sufficient backing for all relevant plans.

The new national strategy should be published and communicated to all interested parties inside and outside the government, including media outlets and the wider public. Regular coordination meetings should be arranged to bring all implementing agencies and partners together to facilitate ongoing cooperation. Progress should continue to be monitored, evaluated and shared through periodic parliamentary and public updates, with a view to identifying areas in need of further policy development.

\subsection{National Action Plans on Business and Human Rights}

Some States have begun to set out their intentions to implement the UNGPs by developing and adopting policy strategies generally known as National Action Plans on Business and Human Rights. ${ }^{74}$ These plans offer a way for governments to summarize existing commitments, establish current priorities and project future undertakings on business and human rights. ${ }^{75}$ Among other things, they can prompt governments to launch reviews of business-related laws and policies, raise businesses' awareness of human and children's rights, promote the formulation and sharing of best practices, and announce new budgetary commitments.

To ensure consistency with international children's rights obligations and national strategies to implement the CRC, governments that decide to prepare National Action Plans on Business and Human Rights should specifically address children's rights. Among other things, these plans should explicitly reference and draw from the CRC, OPAC, OPSC, GC 16 and other relevant children's rights instruments.

74 For guidance on how to develop, implement and update National Action Plans on Business and Human Rights, consult UN Working Group on Business and Human Rights, Guidance on National Action Plans on Business and Human Rights, Version 1.0, December 2014, <www.ohchr.org/Documents/ Issues/Business/UNWG_\%20NAPGuidance.pdf>, accessed 5 January 2015. See also International Corporate Accountability Roundtable and Danish Institute for Human Rights, National Action Plans on Business and Human Rights: A Toolkit for the Development, Implementation, and Review of State Commitments to Business and Human Rights Frameworks, June 2014, <http://accountabilityroundtable.org/wp-content/uploads/2014/06/DIHRICAR-National-Action-Plans-NAPs-Report3.pdf>, accessed 8 January 2015.

75 The European Union's 2011-2014 renewed strategy for Corporate Social Responsibility invites Member States to adopt national action plans to implement the UNGPs. European Commission, A renewed EU strategy 2011-14 for Corporate Social Responsibility, 2011, p. 14, <http://ec.europa.eu/ enterprise/policies/sustainable-business/files/csr/new-csr/act_en.pdf, >, accessed 22 October 2014 


\section{Children's Rights in National Action Plans on Business and Human Rights}

"The [UN] Working Group [on the issue of human rights and transnational corporations and other business enterprises] encourages States... (d) To place concern for the victims of human rights abuses at the heart of national action plans [on business and human rights], paying particular attention to women and groups that are particularly vulnerable to corporaterelated human rights abuses, including children, indigenous peoples, migrant workers and their families, persons with disabilities, ethnic minorities and human rights defenders..."76

\section{Box 29}

Finland's National Action Plan on Business and Human Rights makes clear commitments with respect to children's rights and business. Specifically, the plan states that "Finland shall report to the United Nations Committee on the Rights of the Child on the implementation of the recommendation by the Committee on Business. In addition, [General Comment no. 16] shall be translated into Finnish and Swedish, and a summarized introduction to its contents shall be made for distribution to entities such as companies". ${ }^{77}$

\subsection{Programmatic initiatives on children's rights and business}

Revising national strategies and policy frameworks also presents an opportunity to launch new programmatic initiatives on children's rights and business. As such, governments with the resources to fund and administer grants and other programmes on human rights, economic development and related issues should consider dedicating a portion of these to children's rights and business. The breadth of GC 16 gives scope for introducing this focus both domestically and internationally, covering a large variety of issue and industry-specific priorities.

Programmatic initiatives provide a chance for governments to share and develop expertise on children's rights and business, to foster business and popular cultures for respecting children's rights, and to make direct, practical contributions towards realizing the rights of children. Programming also strongly supports the work of civil society organizations, which are essential partners in advancing the children's rights in relation to business.

\section{Funding Business and Human Rights}

The United Kingdom Foreign Commonwealth Office offers funding to support international projects related to business and human rights through its Human Rights and Democracy Programme. ${ }^{78}$ Similarly, the United States Bureau of Democracy, Human Rights and Labor finances initiatives to encourage economic development and uphold international human rights standards in regions and countries with the greatest need..$^{79}$

76 Report of the Working Group on the issue of human rights and transnational corporations and other business enterprises to the UN General Assembly, UN Doc. A/69/263, 5 August 2014, para. 92.

77 Finnish National Action Plan on Business and Human Rights, p. 15, available at <www.tem.fi/files/41214/TEMjul_46_2014_web_EN_21102014.pdf>, accessed 24 October 2014.

78 Foreign and Commonwealth Office, Human Rights and Democracy Programme, 3 February 2014, <www.gov.uk/human-rights-and-democracyprogramme>, accessed 16 October 2014.

79 United States Department of State, DRL Programs, <www.state.gov/j/drl/p/index.htm>, accessed 16 October 2014. 


\section{Research and data collection}

"To meet their obligation to adopt appropriate and reasonable legislative and regulatory measures to ensure that business enterprises do not infringe on children's rights, States will need to gather data, evidence and research for identifying specific business sectors of concern."-General Comment no. 16, para. 53

Studying Business
and Human Rights
The Netherlands has undertaken a sector risk
analysis to identify the areas of the national economy
most likely to have negative impacts on human
rights. The study explores practical implications
for both governments and businesses, and aims to
serve as an effective basis for engagement with a
view to strengthen adherence to corporate social
responsibility norms and standards. ${ }^{80}$

Through engaging in and supporting research and data collection, States can better assess and shape their progress towards the full realization of international children's rights. Indeed, to select and evaluate appropriate legal and policy responses in light of GC 16, governments should strive to obtain complete and accurate information on the situation of business and children's rights. Research can help to identify which business sectors, operations and activities raise particular concerns with respect to children's rights, and at the same time indicate government responses that could serve to eliminate or mitigate potential negative impacts

As a matter of course, governments should periodically collect statistical data relevant to children's rights and business in order to understand how their laws and policies advance the implementation of the CRC, OPAC and OPSC. With this in mind, governments should develop a set of children's rights and business indicators to track progress in meeting their international obligations. Among other things, using consistent indicators provides for greater accountability by setting clear benchmarks against which later developments can be measured. Indicators can also be matched with related budget lines to show links between progress on children's rights and changes in resource allocation.

Data collection should be coordinated throughout the whole of a State's jurisdiction, and should cover the full age range of children, including infants and adolescents, up to the age of 18 years. This data should be as detailed as is practicable, and be disaggregated wherever possible by age, sex, place of residence, membership in a minority and/or indigenous group, ethnicity, religion, disability, and/or any other relevant demographic factors. ${ }^{81}$ Disaggregating data better enables governments to take the rights of all children into account, and more readily reveals patterns of discrimination in the application of laws and policies.

Measuring Human

\section{Box 32}

\section{Rights Impacts}

The Office of the United Nations High Commissioner

for Human Rights recommends that indicators for

human rights be:

- Simple, timely and few in number;

- Reliable;

- Based on transparent and verifiable methodology;

- In conformity with human rights and international standards;

- Amenable to contextualization and disaggregation. ${ }^{82}$

80 Government of the Netherlands, Putting Corporate Social Responsibility (CSR) into Practice, <www.government.nl/issues/corporate-socialresponsibility-csr/putting-corporate-social-responsibility-csr-into-practice>, accessed 19 October 2014.

81 See, e.g., Committee on the Rights of the Child, Guidelines on the inclusion of statistical information and data in periodic reports to be submitted by States parties under article 44, paragraph 1(b), of the Convention, para. 1, Annex to Treaty-specific guidelines regarding the form and content of periodic reports to be submitted by States parties under article 44, paragraph 1 (b), of the Convention on the Rights of the Child, UN Doc. CRC/C/58/ Rev.2, 23 November 2010.

82 Office of the High Commissioner for Human Rights, Human Rights Indicators, A guide to Measurement and Implementation, $2012, \mathrm{pp} .50-51$. 
Data sets and research findings should be disseminated widely among governmental authorities to bring a more coherent, evidence-based approach to realizing children's rights, and anonymized information should be made publicly available to foster wider awareness and debate. Governments should also share, draw from and expand upon existing sources of reliable data, including statistics maintained by specialized United Nations agencies with mandates that touch on business and children's rights. ${ }^{83}$ By the same token, governments should consider collaborating with academic and research institutions, and may wish to sponsor qualitative or empirical studies that, for instance, map business sector impacts on children's rights or otherwise add to the knowledge base on children's rights and business.

\section{Understanding Child Labour}

\section{Box 33}

Child labour includes work too hazardous for children to perform and work performed by children under the minimum age for employment, as defined under national and international law. ${ }^{84}$ It can be considered inherently harmful to children's well-being and development, and is both a cause and consequence of poverty. Child labour is also a complex issue with many contributing factors, and measures to address or eliminate child labour require a holistic, evidence-based approach. With this in mind, the Department of Social Welfare in Tanzania initiated a project to assess the performance of local child protection systems in preventing and addressing instances of child labour. Results revealed not only inadequate response structures, but also a critical lack of information management systems. Consequently, the government has offered support to strengthen the collection and analysis of key child protection data, including information related to child labour. ${ }^{85}$

Research should aim to accurately reflect concerns around children's rights, and it is thus essential that children be meaningfully engaged in data collection wherever they are uniquely placed to indicate whether and how their rights are being realized. Inclusive research seeks out children's perspectives through surveys, interviews and focus groups, and children can also be empowered to conduct research themselves with appropriate protections in place. ${ }^{86}$

83 For example, the ILO has a database of child labour statistics; the WHO collects primary health statistics in consultation with member States; UNAIDS gathers estimates, progress reports and national commitments on HIV and AIDS; UNICEF publicizes data on children and women, including child labour; and UNESCO maintains a database on education statistics.

84 International legal standards on child labour include ILO Convention No. 182 on the worst forms of child labour and ILO Convention No. 138 on the minimum age for admission to employment and work.

85 United Nations Children's Fund, Child Labour and UNICEF in Action: Children at the Centre, 2014, <www.unicef.org/protection/files/Child_Labour_ and UNICEF_in Action.pdf>, accessed 16 October 2014.

86 See, e.g., Lansdown, Gerison, Promoting Children's Participation in Democratic Decision-Making, Innocenti Insight 6, UNICEF Office of Research Innocenti, 2001, <wWw.unicef-irc.org/publications/pdf/insight6.pdf>, accessed 5 December 2014. 


\section{Monitoring}

"States have an obligation to monitor violations of the Convention and the Optional Protocols thereto committed or contributed to by business enterprises, including in their global operations. This can be achieved, for instance, through: gathering data that can be used to identify problems and inform policy; investigating abuses; collaborating with civil society and national human rights institutions; and making business accountable publicly by using business reporting on their impact on children's rights to assess their performance." -General Comment no. 16, para. 76

Governments should actively monitor the ways in which business activities, operations and relationships impact on children's rights. Regulatory agencies and authorities in particular play a vital role in this process, especially when business enterprises have been entrusted to deliver services that are critical to the enjoyment of children's rights. Governments should also empower and participate in external institutions and mechanisms that examine business impacts on children's rights. They should not only support and engage with existing global and regional bodies that address children's rights and business issues, but also establish or strengthen independent institutions, including national human rights institutions, on the national level to do the same.

\subsection{Regulatory agencies and authorities}

Administrative authorities with oversight and accountability powers and responsibilities can play an important role in ensuring that businesses comply with national laws and regulations relevant to children's rights. Labour ministries, for instance, may play a vital role in preventing child labour and assuring suitable terms of employment, working conditions, and health and safety standards for parents and caregivers by conducting inspections to assess whether businesses are respecting relevant laws and regulations. Similarly, consumer protection agencies can conduct investigations and site visits to ensure that businesses' goods and services are produced and provided in line with quality, health and safety standards.

Some governments have contracted or otherwise allowed private companies to provide education, health care, transportation, basic utilities like water, sanitation and electricity, and other services upon which children depend. Importantly, however, governments cannot outsource their children's rights obligations, and thus retain the ultimate responsibility for the delivery of essential services. ${ }^{87}$ Without adequate regulation and monitoring, contracting businesses may fail to deliver services of sufficient quality and quantity in a fair, equal and accessible way. To ensure that private service providers respect children's rights, then, regulatory agencies should be given supervisory authority to oversee the delivery of services in line with national law and international children's rights standards.

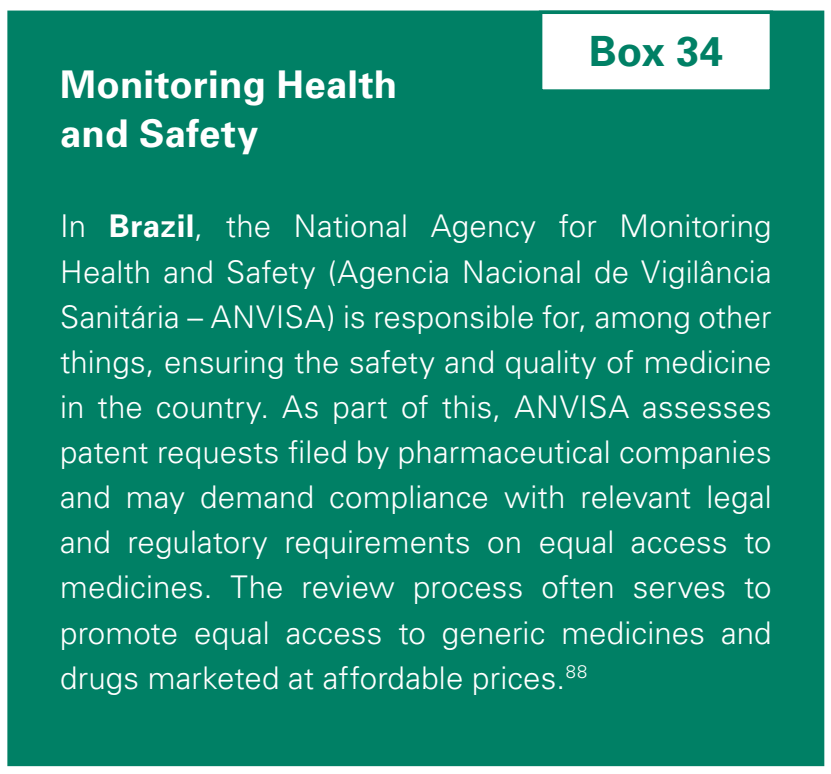

\section{Labour Inspectorates}

Box 35 in Concluding Observations: Myanmar

"The Committee recalls its previous concluding observations ... and strongly recommends that the State party: ... (e) Improve labour inspections to ensure that these comprehensively monitor all aspects of the work environment, including the use of child labour". ${ }^{89}$

87 Committee on the Rights of the Child, General Comment no. 16 on State obligations regarding the impact of the business sector on children's rights, UN Doc. CRC/C/GC/16, 17 April 2013, para. 33

88 ANVISA, Resolution RDC No 45 of 23 June 2008, cited in International Commission of Jurists, Conectas, Acesso à Justiça: Violações de Direitos Humanos por Empresas: Brasil, ICJ and Conectas, Geneva, 2011, p. 42.

89 Committee on the Rights of the Child, Concluding Observations to Myanmar, UN Doc. CRC/C/MMR/CO/3-4, 14 March 2012, para. 86. 


\section{Privatization}

Kenya has sought to manage private sector

involvement in providing water services, and

now explicitly recognizes the right to water in its

Constitution. Reforms undertaken include the

creation of a regulatory institution to set and ensure

compliance with tariff regulations and minimum

standards for water quality, the establishment of a

complaints mechanism for water related concerns,

and the introduction of measures to empower

consumers to negotiate with water service

providers. ${ }^{90}$

\section{Privatization in Concluding Observations: Lebanon}

"The Committee recommends that the State Party...

(b) Provide non-governmental organizations with adequate financial and other resources when they are involved in discharging governmental responsibilities and duties with regard to the implementation of the Convention;

(c) Ensure, for example, by providing guidelines and standards for service provision that nongovernmental organizations, both for-profit as well as not-for-profit, fully comply with the principles and provisions of the Convention on the Rights of the Child; and

(d) When privatizing or contracting out services to non-governmental organizations, enter into detailed agreements with the service providers, ensure effective monitoring of implementation as well as transparency of the entire process." ${ }^{11}$

\subsection{International monitoring mechanisms}

"States should include information in their periodic reporting to the Committee on the challenges they face and the measures they have taken to respect, protect and fulfil children's rights in the context of the activities and operations of business enterprises both domestically and, where appropriate, transnationally."

-General Comment no. 16, para. 86

As part of their obligations under the CRC, OPAC and OPSC, governments must submit regular reports to the Committee on how children's rights have been implemented within their jurisdiction. These reports cover the full spectrum of rights, and GC 16 calls on governments to include information about the role of the private sector in realizing children's rights and any steps envisaged or taken to shape the impacts of business activities and operations on children. ${ }^{92}$ This not only allows the Committee to recommend targeted measures for individual governments to improve the situation of children's rights with respect to the business community, but also contributes to both the Committee's general understanding of the subject matter and its ability to guide other governments facing similar challenges.

90 De Albuquerque, Catarina, On the Right Track - Good practices in realizing the rights to water and sanitation, Lisbon, 2012, pp. 65-66 <www.ohchr. org/Documents/Issues/Water/BookonGoodPractices_en.pdf>, accessed 5 December 2014.

91 Committee on the Rights of the Child, Concluding Observations to Lebanon, UN Doc. CRC/C/LBN/CO/3, 8 June 2006, para. 22.

92 The Committee has adopted Treaty-specific guidelines regarding the form and content of periodic reports to be submitted by State parties under article 44, paragraph 1 (b) of the CRC to facilitate and standardize the reporting process. In these guidelines, the Committee specifies that State party reports should be limited to 60 pages, with information organized into the following clusters: general measures of implementation (arts. 4,42 and 44 para. 6); definition of the child (art. 1); general principles (arts. 2, 3, 6 and 12); civil rights and freedoms [arts. 7, 8, 13-17, 28.2, 37(a) and 39]; family environment and alternative care [arts. 5, 9-11, 18 (paras. 1 and 2), 19-21, 25, 27 (paras. 4) and 39]; disability, basic health and welfare [arts. 6, 18 (para. 3), 23, 24, 26, 27 (paras. 1-3) and 33]; education, leisure and cultural activities (arts. 28, 29, 30 and 31); and special protection measures [arts. $22,30,32-36,37(b)-(d), 38,39$ and 40$]$. 


\section{Reporting to the Committee on the Rights of the Child}

The Committee has published reporting guidelines that call on States parties to the CRC, OPAC and OPSC to provide information on the ways in which business operations and activities impact children's rights. Relevant requests include:

\section{CRC}

"[T]he State party should include relevant and updated information in relation to the Convention [on the Rights of the Child] and its Optional Protocols, as applicable, in particular on... [e]fforts undertaken or foreseen to make reports and concluding observations widely available to the public at large, to civil society, business organizations and labour unions, to religious organizations, the media, and others as appropriate..."93

"States parties are requested to provide information on whether the impact of activities by business corporations (extractive, pharmaceutical, agro-industry, among others) likely to affect the enjoyment by children of their rights are evaluated and whether measures are taken to investigate, adjudicate, repair and regulate."94

\section{OPAC}

"Reports should contain a description of any law concerning the criminal liability of legal persons, such as private military and security companies (PMCs and PSCs), for the acts and activities enumerated in the [OPAC], and comments on the effectiveness of such laws as a deterrent to the recruitment of children. If the law of the State party does not recognize the criminal liability of legal persons for such offences, the report should explain why this is so and the position of the State party on the feasibility and desirability of modifying it." 95

"The State party should indicate whether its national legislation prohibits the trade and export of small and light arms as well as military assistance to countries where children are involved in armed conflict. If not, it should indicate whether consideration is given to the possibility of adopting such legislation." ${ }^{96}$

\section{OPSC}

"Reports should describe any campaigns or other measures that have been taken to promote public awareness of the harmful consequences of the sale of children and child prostitution and pornography...including...

(c) The role played by NGOs, the media, the private sector and the community, in particular children, in the design and implementation of the awareness measures described above; and

(d) Any steps taken to measure and evaluate the effectiveness of the measures described above, and the results obtained." $" 97$

"Reports should describe any law concerning the criminal liability of legal persons for the acts and activities enumerated...and comment on the effectiveness of such laws as a deterrent to the sale of children, child prostitution and child pornography; if the law of the State party does not recognize the criminal liability of legal persons for such offences, the report should explain why this is so and the position of the State party on the feasibility and desirability of modifying it." 98

93 Ibid., para. 19.

94 lbid., para. 20.

95 Committee on the Rights of the Child, Revised guidelines regarding the initial reports to be submitted by State parties under article 8 , paragraph 1 of the Optional Protocol to the Convention on the Rights of the Child on involvement of children in armed conflict, UN Doc. CRC/C/OPAC/2, 19 October 2007, para. 23.

96 Ibid., para. 34

97 Committee on the Rights of the Child, Revised guidelines regarding the initial reports to be submitted by State parties under article 12 , paragraph 1 of the Optional Protocol to the Convention on the Rights of the Child on the sale of children, child prostitution and child pornography, UN Doc. CRC/C/ OPSC/2, 3 November 2006, para. 15

98 Ibid., para. 18. 
In addition, there are a number of other mechanisms within the United Nations that also cover children's rights and business. Notably, the United Nations has a mandate to appoint a range of independent experts known as "Special Procedures" to study, monitor and advise on human rights in a particular country or in relation to a particular issue. ${ }^{99}$ Within these, the Working Group on the issue of human rights and transnational corporations and other business enterprises is specifically concerned with monitoring business impacts on human rights, while other procedures like the Working Group on mercenaries and private security companies and the Special Rapporteur in the field of cultural rights look at the role and impact of businesses in reference to certain rights or situations. ${ }^{100}$

Special Procedures can hold public hearings, issue statements and reports, develop guidance, conduct country visits, and raise potential human rights concerns to international attention. In some instances, they can even receive complaints directly from the public about potential rights violations and abuses. States should cooperate with all Special Procedures, including the Working Group on business and human rights, and should emphasize the special importance of children's rights within this work wherever possible and appropriate.

\title{
4.3 National human rights institutions and children's ombudspersons
}

\begin{abstract}
"[N]ational human rights institutions can be involved, for example, in...conducting public inquiries into large-scale abuses, mediating in conflict situations and undertaking legislative reviews to ensure compliance with the Convention. Where necessary, States should broaden the legislative mandate of national human rights institutions to accommodate children's rights and business." -General Comment no. 16, para. 76
\end{abstract}

States should establish or strengthen existing independent human rights bodies with the power to monitor and investigate business sector impacts on children and recommend public sector responses. ${ }^{101}$ These may take the form of national human rights institutions (NHRIs) with an explicit mandate to protect human rights, or children's ombudspersons or commissioners that enjoy a similar competency solely with respect to children's rights. Regardless of their nature, all institutional mandates should incorporate and apply the CRC, OPAC and OPSC. The creation of a separate children's ombudsperson or commissioner guarantees a more specific focus on children, but designated divisions or units may likewise address children's rights issues within larger institutions.

NHRIs and children's ombudspersons or commissioners should operate transparently, with impartiality and in

\section{Land Use}

Box 38

Business acquisition of community, public and individually owned property rights can negatively impact the enjoyment of children's rights. Environmental degradation from land use can decrease the availability of food and access to clean water and sanitation, while forced evictions may cause interruptions in education, reduce access to health care, result in scarcities in adequate housing, raise problems related to social exclusion, and increase risks of trafficking and exploitation. In this context, the Kenya National Human Rights Commission launched a public inquiry into community displacements resulting from the coastal salt manufacturing industry. The Commission uncovered numerous human rights violations and abuses, including issues related to harassment, inadequate compensation, corruption, poor labour conditions and pollution; identified the roles and responsibilities of all public and private sector actors involved; and issued targeted recommendations to both government and business. In addition, the Commission proactively organized consultations with local communities to inform them of their rights and discuss the potential impacts of future business projects. ${ }^{102}$

accordance with international standards, particularly the Paris Principles. ${ }^{103}$ These institutions should have full legal, operational and financial autonomy; support from the highest levels of government; and the authority, expertise and resources necessary to assess businesses' compliance with children's rights obligations. They should also be accessible to all children without discrimination, and should proactively contact and consult with children and their representatives through suitable channels in order to better understand, represent and promote their views and experiences.

\footnotetext{
99 A full list of the Special Procedures of the Human Rights Council is available at <www.ohchr.org/en/HRBodies/SP/Pages/Welcomepage.aspx> accessed 21 October 2014.

100 See, for example, Report of the Special Rapporteur in the field of cultural rights, UN Doc. A/69/286, 8 August 2014.

101 See Principles relating to the Status of National Institutions ("Paris Principles"), adopted by the UN General Assembly in Resolution $48 / 134$ of 20 December 1993, <www.ohchr.org/EN/Professionallnterest/Pages/StatusOfNationallnstitutions.aspx>, accessed 5 December 2014.

102 The Report of the Malindi Inquiry is available at <www.knchr.org/Portals/0/Reports/Malindi_Inquiry.pdf>, accessed 17 October 2014.

103 The Principles Relating to the Status of National Institutions ("Paris Principles"), set out guidelines for the establishment of independent human rights institutions to promote and protect human rights. See id.; for a general overview of the Principles relating to the Status of National Human Rights Institutions ("Paris Principles"), consult <www.ohchr.org/Documents/Publications/PTS-4Rev1-NHRI_en.pdf>, accessed 9 April 2014. The Committee on the Rights of the Child has given similar guidance with reference to children's ombudspersons and commissioners in its General Comment no. 2 (2002) on the role of independent national human rights institutions in the protection and promotion of the rights of the child.
} 
NHRIs on Business and Human Rights

In 2010, the International Co-ordinating Committee of National Institutions for the Promotion and Protection of Human Rights (ICC) issued the Edinburgh Declaration to encourage NHRIs to incorporate business and human rights in their work by, among other things:

- Monitoring States' and non-state actors', including businesses', compliance with human rights;

- Advising all actors on how to prevent and remedy rights abuses arising from the conduct of business;

- Providing and/or facilitating access to judicial and/or non-judicial remedies, for example by supporting victims, handling complaints and/or undertaking mediation and conciliation;

- Conducting research and undertaking education, promotion and awareness-raising activities; and

- Integrating human rights and business elements in interactions with international human rights bodies, including United Nations treaty bodies, Special Procedures, the Human Rights Council and the Universal Periodic Review, as well as regional human rights mechanisms. ${ }^{104}$ 


\section{Raising awareness}

"While it is the State that takes on obligations under the CRC, the task of implementation needs to engage all sectors of society including business, civil society and children themselves."

-General Comment no. 16, para. 82

Governments not only have the power to regulate business activities, operations and relationships, but are also uniquely positioned to engage a wider range of actors with a role in realizing children's rights. While the primary responsibility to implement international children's rights rests with the public sector, GC 16 makes clear that governments must engage businesses, children and civil society organizations in so doing. Beyond disseminating GC 16 widely within these groups, governments should launch much broader education and awareness-raising programmes to create a strong, inclusive foundation for advancing children's rights, including in relation to business.

\section{Raising Businesses' Awareness} on Children's Rights

\section{Box 40}

In 2014, Canada endorsed and helped to launch the Children's Rights and Business Principles alongside companies, civil society organizations and the media. The event highlighted the links between children's rights and business, underscored the need to operate in the best interests of children both within and outside the country, and encouraged companies to take practical steps to respect children's rights in their activities and operations. ${ }^{105}$

\subsection{Businesses}

"Education, training and awareness-raising about the CRC should also be targeted at business enterprises to emphasize the status of the child as a holder of human rights, encourage active respect for all of the Convention's provisions and challenge and eradicate discriminatory attitudes towards all children and especially those in vulnerable and disadvantaged situations."

-General Comment no. 16, para. 82

Governments should foster a business culture that respects and supports children's rights, advocating for companies to integrate this responsibility into their internal by-laws and procedures, core values, policies and strategies. Chambers of commerce, industry groups, professional societies and other business associations can be important channels for communicating with companies, and governments should consider using these to proactively work with companies. By organizing joint seminars, for instance, governments can strive to shift corporate perceptions of children's rights in explaining how business plays an increasingly larger role in children's lives. Panels and roundtables might provide a forum for business to have more in-depth discussions on common difficulties or concerns that touch on children's rights, and may help to build a network for sharing ideas and good practices. To encourage deeper professional understanding of children's rights and business, governments could also support the inclusion of relevant modules in curricula for business, law and other related disciplines.

\footnotetext{
105 UNICEF, Canadian National Release of the Children's Rights and Business Principles, 13 February 2014, Events, <www.unicef.org/csr/>, accessed 8 January 2014; Government of Canada, Foreign Affairs, Trade and Development, Address by Parliamentary Secretary Lois Brown: Canadian Launch of the Children's Rights and Business Principles, 13 February 2014, <www.international.gc.ca/media/dev/speeches-discours/2014/02/13a. aspx?lang=eng $>$, accessed 8 January 2014
} 


\section{Sharing Human Rights Information with Businesses}

A substantial number of governments make information about human and children's rights available to the business community:

- The United States publishes annual reports on child labour in over 90 countries, and maintains a list of goods and source countries believed to be products of child or forced labour. ${ }^{106}$

- The United Kingdom provides information about the business environment and situation of human rights in countries in which the Department of Trade and Investment has a presence, and gives general guidance about the implementation of business and human rights standards. ${ }^{107}$

- The Netherlands maintains a website with guidelines and resources for business on corporate social responsibility, ${ }^{108}$ and has also launched an online tool to help businesses understand and limit human rights risks within their value chains. ${ }^{109}$

- In collaboration with the Confederation of Danish Industry, Denmark has developed an online tool for small and medium-sized enterprises on responsible supply chain management. ${ }^{110}$

- The European Union has funded and disseminated a series of sector-specific guides on implementing the UNGPs. ${ }^{111}$
Governments can also serve as a valuable information resource on business and children's rights. Through online platforms and information centres, governments can offer companies tools and guidance on respecting children's rights across their activities, operations and relationships. These can provide instruction on topics like due diligence requirements and reporting obligations, and also push businesses to go beyond their legal obligations and become champions for children's rights. Furthermore, where there are specific issues of concern, governments can supply more targeted data on children's rights risks associated with certain contexts, geographic areas or sectors of the economy. This might even be undertaken in conjunction with overseas missions and embassies, which have both international expertise and specialized local knowledge that may help to avoid or mitigate potential negative impacts on children's rights in a given situation.

\subsection{Children}

"The Committee recommends that States adopt and implement a comprehensive strategy to inform and educate all children, parents and caregivers that business has a responsibility to respect children's rights wherever they operate, including through child-friendly and age appropriate communications, for example through provision of education about financial awareness."

\section{- General Comment no. 16, para. 82}

As rights-holders, it is essential for children to understand that companies have responsibilities towards them. Accordingly, governments should launch public campaigns to educate and inform children, parents and caregivers about children's rights in relation to business. These can be rolled out in schools and other places visited by children, with the assistance of children's clubs or organizations, and through traditional and digital media. Information should be accessible and child friendly, and be designed to reach as wide an audience as possible. It should aim to show how the private sector can impact children's rights in both positive and negative ways, and explain how both governments and businesses must take steps to protect children from negative impacts. Details should also be provided on how children and their representatives can seek access to an effective remedy when their rights have been infringed by a business.

106 United States Department of Labor, Child Labor, <www.dol.gov/ilab/issues/child-labor/>, accessed 17 October 2014.

107 Foreign \& Commonwealth Office, UK Trade \& Investment, Information for UK businesses on how to identify and guard against security and political risks when trading overseas, 15 October 2014, <www.gov.uk/government/collections/overseas-business-risk>, accessed 17 October 2014.

108 Government of the Netherlands, Putting Corporate Social Responsibility into Practice, <www.government.nl/issues/corporate-social-responsibilitycsr/putting-corporate-social-responsibility-csr-into-practice>, accessed 17 October 2014.

109 MVO Nederland, CSR Risk Check, <www.mvorisicochecker.nl/en>, accessed 23 October 2014.

110The CSR compass is available at <www.csrcompass.com>, accessed 17 October 2014.

111 The guides are available at <wWw.ihrb.org/publications/reports/ec-sector-guides>, accessed 17 October 2014. 


\section{Education on Child Trafficking}

Human trafficking can be found in countries around the world, touching nearly every sector of the global economy and involving businesses of all shapes and sizes. Trafficking is not only a serious infringement of children's rights in and of itself, but also leaves child victims especially vulnerable to further violence and exploitation. While States should take strong legal measures to combat child trafficking, it is likewise important to ensure that children, caregivers and educators understand the related risks, relevant rights and available remedies. To raise awareness of human trafficking and national prevention programmes, Azerbaijan has piloted classes on the issue in schools, held roundtables and training sessions for parents and teachers, and launched wider public campaigns. Similarly, Ukraine has worked with the Council of Europe to incorporate lessons on human trafficking into educational curricula. ${ }^{112}$

\subsection{Civil society}

"Civil society has a critical role in the independent promotion and protection of children's rights in the context of business operations. This includes monitoring and holding business accountable; supporting children to have access to justice and remedies; contributing to child-rights impact assessments; and raising awareness amongst businesses of their responsibility to respect children's rights." -General Comment no. 16, para. 84

Civil society organizations and human rights defenders play a crucial role in promoting and protecting human rights, and governments should enable, support and work with civil society to raise the profile of children's rights and business. Many civil society organizations have strong community links, and will be able to place GC 16 in the local context. For the same reasons, civil society is often more directly aware of how businesses affect children's lives on a practical, day to-day level. To enable their work, civil society organizations should be encouraged and empowered to share information about corporate impacts on children's rights, and to challenge those responsible for potential rights abuses.

\section{Fighting Child Pornography}

\section{Box 43}

While financial institutions are rarely directly involved in the production or distribution of child pornography, the services they offer may inadvertently facilitate transactions to buy or sell images of child sexual exploitation. In response, civil society organizations in the United States, Singapore, Sweden and the European Union have convened financial coalitions against child pornography to bring together credit card and electronic payment companies, law enforcement agencies and Internet service providers to jointly work towards eradicating child pornography. ${ }^{113}$

112The Protection Project, Best Practices in Combating Trafficking in Persons: The Role of Civil Society, 2012, pp. 85-86, <www.ungift.org/doc/ knowledgehub/resource-centre/CSOs/100-Best-Practices-in-Combating-TIP.pdf>, accessed 18 October 2014.

113Financial Coalition Against Child Pornography, <www.icmec.org/missingkids/servlet/PageServlet? LanguageCountry=en_X1\&Pageld=3064>, accessed 18 October 2014; Swedish Financial Coalition Against Child Pornography, <www.financialcoalition.se>, accessed 18 October 2014 European Financial Coalition against Commercial Sexual Exploitation of Children Online, <www.europeanfinancialcoalition.eu/index.php >, accessed 18 October 2014 


\section{Remedies}

"States have an obligation to provide effective remedies and reparations for violations of the rights of the child, including by third parties such as business enterprises... Meeting this obligation entails having in place child-sensitive mechanisms - criminal, civil or administrative - that are known by children and their representatives, that are prompt, genuinely available and accessible and that provide adequate reparation for harm suffered." -General Comment no. 16, para. 30

In the words of the Committee on the Rights of the Child, "[f]or rights to have meaning, effective remedies must be available to redress violations." 114 Children's right to an effective remedy is both an "implicit requirement in the $[\mathrm{CRC}] ", 115$ and a general principle of law enshrined in other international human rights treaties. ${ }^{116}$ As such, States have an obligation to ensure that children and their representatives have full access to justice for infringements of their rights. This applies equally to all rights whether civil, political, economic, social or cultural, and extends to abuses stemming from business activities, operations and relationships. ${ }^{117}$

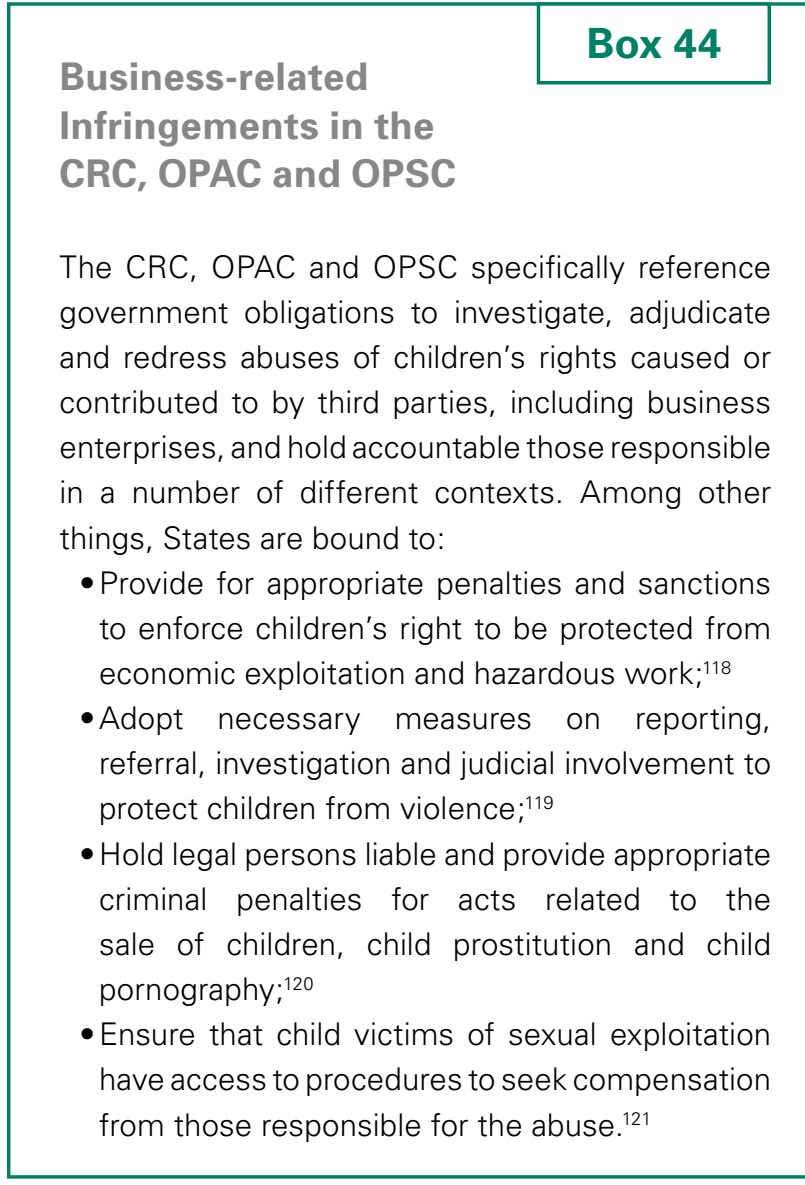

Remedies in

\section{Box 45}

"[T]he Committee recommends the State party:... (c) Take measures to ensure that its companies respect child rights in its territory and when engaging in projects abroad and that appropriate remedies, including reparations are pursued in cases of violations..."122

114Committee on the Rights of the Child, General Comment no. 5: General measures of implementation of the Convention on the rights of the Child (arts. 4, 42, 44, para. 6), UN Doc. CRC/GC/2003/5, 27 November 2003, para. 24.

$115 \mathrm{lbid}$

116See, e.g., article 2.3 of the International Covenant on Civil and Political Rights: "Each State Party to the present Covenant undertakes: (a) To ensure that any person whose rights or freedoms as herein recognized are violated shall have an effective remedy, notwithstanding that the violation has been committed by persons acting in an official capacity; (b) To ensure that any person claiming such a remedy shall have his right thereto determined by competent judicial, administrative or legislative authorities, or by any other competent authority provided for by the legal system of the State, and to develop the possibilities of judicial remedy; (c) To ensure that the competent authorities shall enforce such remedies when granted."

117See, e.g., Committee on the Rights of the Child, General Comment no. 11, Indigenous children and their rights under the convention, UN Doc. CRC/C/ GC/11, 12 February 2009, para. 23

118 See CRC art. 32.2(c).

119See CRC art. 19.2

120 See OPSC art. 3.

121 See OPSC art. 9.4.

122 Committee on the Rights of the Child, Concluding Observations to Thailand, UN Doc. CRC/C/THA/CO/3-4, 17 February 2012, para. 30. 


\subsection{Children in the justice system}

“Children's special and dependant status creates real difficulties for them in pursuing remedies for breaches of their rights. So States need to give particular attention to ensuring that there are effective, child-sensitive procedures available to children and their representatives." -General Comment no. 5, para. 24

Children in contact with the justice system require special attention, both in view of their rights under the CRC, OPAC and OPSC and because childhood constitutes a unique period of physical, mental, emotional and spiritual development. With this in mind, justice systems must not only recognize children as persons in need of protection, but also strive to empower children as active participants in legal proceedings. Specifically, in light of the CRC, justice systems should:

- Recognize children's best interests as of primary importance, acknowledging children's evolving capacities and considering each child individually in light of his/her needs, background and social context, and stage of development; ${ }^{123}$

- Ensure that children are given an opportunity to express their views, either directly or through an appropriate representative, and that these views are given due consideration; ${ }^{124}$

- Guarantee equal access for all children, noting that children in vulnerable situations such as migrant children, indigenous children and members of ethnic minority groups may require additional support; ${ }^{125}$

- Provide for adequate reparations, including restitution, compensation and measures to promote children's recovery, rehabilitation and reintegration. ${ }^{126}$

\subsection{Judicial remedies}

"States should focus their attention on removing social, economic and juridical barriers so that children can in practice have access to effective judicial mechanisms without discrimination of any kind." -General Comment no.

\section{6, para. 68}

Although available remedies vary in line with legal practices and traditions, judicial mechanisms like civil and criminal courts or more specialized tribunals are an essential means of seeking redress. Children and their representatives should be able to seek reparations through civil claims for any harm caused directly from those responsible, including from business, and States should also use judicial mechanisms to prosecute rights abuses where these amount to criminal offences. Criminal proceedings not only provide or facilitate reparations for child victims, but also send strong messages of deterrence.

\section{Child-friendly Justice}

\section{Box 46}

The Council of Europe has developed Guidelines on child-friendly justice to help and encourage governments to adapt their justice systems to the rights and needs of child victims, witnesses, offenders and complainants. As defined in the Guidelines, a child-friendly justice system "guarantees the respect and the effective implementation of all children's rights, giving due consideration to the child's level of maturity and understanding and to the circumstances of the case. It is, in particular, justice that is accessible, age appropriate, speedy, diligent, adapted to and focused on the needs and rights of the child, respecting the rights of the child including the rights to due process, to participate in and to understand the proceedings, to respect for private and family life and to integrity and dignity." ${ }^{\text {"127 }}$

\section{Criminal Liability for} Business Enterprises

\section{Box 47}

In France, legal persons including corporations and other business entities may be held criminally responsible for their actions. Specifically, the French Criminal Code provides that "[j]uridical persons, with the exception of the State, are criminally liable for the offences committed on their account by their organs or representatives" as detailed in the Code and in other cases provided for by law. ${ }^{128}$ In contrast, companies cannot be directly prosecuted in Colombia or Peru, but are liable for the criminal acts of directors and managers in certain circumstances. ${ }^{129}$

\footnotetext{
123 See CRC arts. 3.1 and 5.

124 See CRC art. 12.

125 See CRC art. 2.

126 See CRC art. 39.

127 Council of Europe, Guidelines of the Committee of Ministers of the Council of Europe on child friendly justice, 2010, <https://wcd.coe.int/ViewDoc. jsp? Ref =CM/Del/Dec(2010)1098/10.2abc \& Language =lanEnglish\&Ver=app6\&Site=CM\&BackColorlnternet=C3C3C3\&BackColorlntranet=EDB0 21\&BackColorLogged =F5D383>, accessed 22 October 2014.

128 See French Criminal Code, art. 121-2.

129 International Commission of Jurists, Acceso a la Justicia: Casos de Abusos de Derechos Humanos por parte de empresas: Colombia, ICJ, Geneva, 2010, p. 12
} 
To be effective, judicial remedies must be provided by independent and impartial authorities established under the law; the proceedings must comply with fundamental principles of due process and fair trial; ${ }^{130}$ and the resulting judgments must be enforceable. Yet, even when these criteria are met, children may still face numerous challenges in using judicial mechanisms. Many of these are exacerbated with respect to business-related violations and infringements, and some of the more common obstacles are set out in greater detail below. Governments should proactively and systematically work to remove these and other barriers to children's access to justice.

\section{Overcoming Barriers to Access to Justice for Children}

\section{Challenge}

\section{Legal and other assistance}

\section{Explanation}

Bringing legal cases to challenge business-related violations or infringements of children's rights can be a costly endeavour, yet legal aid is rarely extended to would-be child complainants. This may place heavy burdens on individual child claimants and their representatives, whereas businesses typically have far greater financial and legal resources available to support their involvement in proceedings. As such, many if not most child victims of business-related rights violations or infringements are unable to secure or fund legal assistance to pursue their claims. Even where assistance is available, lawyers may be too unfamiliar with children's rights, issues and particular concerns to offer effective representation.

\section{Enabling Measures}

Provide, support and facilitate legal assistance for child victims of business-related rights violations or infringements, including those who reside abroad, through official legal aid programmes and relationships with legal service providers, such as community-based legal service organizations, NHRIs, non governmental organizations, university-based legal aid clinics and pro bono arrangements.

Authorize collective complaints, class action lawsuits and other forms of group litigation to address multiple, similar violations or infringements of children's rights together in a single matter, provided that proceedings are consistent with the rights of child complainants, including the right to be heard.

Offer and require training in children's rights to legal professionals working with children, and develop codes of ethics and professional responsibility to guide legal representation of children. Consider collaborating with bar associations, children's rights organizations and other interested groups. 


\section{Complexity of the legal system}

\section{Standing}

Justice systems and lega proceedings can be highly complex and often hard for children and their representatives to navigate. Among other difficulties, children may not fully understand the range of remedies available, the documents and procedures necessary to bring a claim, the way cases work their way through the system, and the kinds of arguments that are presented at court hearings.
Prepare and disseminate accessible, user-friendly guides on processes and requirements for filing legal complaints, including through online channels and in schools, police stations, medical centres and other public spaces.

Launch educational campaigns to raise awareness of the avenues available for children to seek redress for business-related violations or infringements of their rights, including, for example, court visits and the presentation of moot court proceedings.

Establish and support free legal advice centres and helplines to provide child-friendly information and assistance. (See above for information on legal assistance).

Belarus holds children's rights-themed writing and art competitions to educate and empower children in a creative, accessible way. ${ }^{131}$

The Ministry of Education, Youth, and Sport in Cambodia conducts regular training sessions on children's rights for directors and teachers in primary and high schools across the country. ${ }^{132}$

Uganda has launched a national child helpline as "an avenue for reporting incidents of violence, speaking out, seeking emergency assistance, and getting information on available services specifically for children." ${ }^{133}$

In many justice systems, children are not permitted to initiate legal proceedings on their own, either as individuals or groups. They may be forced to seek the permission of their parents or guardians to file a case, or be required to have the approval of the court or assistance of a designated adult to initiate proceedings. This may effectively deny children access to justice, especially where business ties with communities and caregivers pose conflicts of interest. For instance, children may encounter great difficulty bringing claims against prominent local employers.
Give all children standing to file complaints in their own name, with or without representation, as a matter of law and without the need for official authorization or other forms of approval.

Where assistance is desired, ensure that children have access to suitable adult representatives without conflicting interests.

Allow legitimate third parties to bring complaints on behalf of child victims and, as recommended above, authorize collective complaints or other forms of group litigation.

South Africa recognizes the legal standing of children to lodge complaints and institute civil proceedings directly before judicial and other authorities. ${ }^{134}$

131 Office of the High Commissioner for Human Rights, Access to Justice for Children, Report of the United Nations High Commissioner for Human Rights, UN Doc. A/HRC/25/35, 16 December 2013, para. 18

132 lbid., para. 35

133 Republic of Uganda, Ministry of Gender, Labour \& Social Development, Uganda Child Helpline, <http://childhelpline.mglsd.go.ug>, accessed 23 October 2014; see also Daily Monitor (e-paper), Government launches child helpline, 17 June 2014, <www.monitor.co.ug/News/National/ Government-launches-child-helpline/-/688334/2350832/-/necmkj/-/index.html>, accessed 20 October 2014.

134 Office of the High Commissioner for Human Rights, Access to Justice for Children, Report of the United Nations High Commissioner for Human Rights, UN Doc. A/HRC/25/35, 16 December 2013, para. 37. 


\section{Corporate structures}

\section{Jurisdiction/ extraterritoriality}

\section{Time limits}

Businesses increasingly operate across borders and as corporate conglomerates through networks of subsidiaries, commercial associations, joint ventures, contractors and subcontractors. These structures make it difficult to determine the extent to which specific legal entities are responsible for rights abuses, and may limit the assets available to cover reparations.

Determining liability can be particularly challenging for rights abuses that occur outside the country where the business involved has its domicile or base of operations, and restricted interpretations of court jurisdiction may leave affected children without recourse to an effective judicial remedy.
Clarify under the law when the actions or omissions of one business entity can be considered complicit with rights abuses committed by another entity, and determine the corresponding liabilities of all entities involved.

Define the legal conditions under which liability for business related infringements of children's rights can be extended to parent companies of subsidiaries that operate abroad. To prevent infringements, consider imposing legal obligations on businesses to exercise due diligence in overseeing the actions of their subsidiaries.

Grant courts jurisdiction over claims concerning overseas infringements of children's rights involving businesses based in or operating within the country.

Recognize universal jurisdiction for serious human rights abuses, and allow child victims to bring cases in national courts where other available forums do not offer effective remedies.

The European Union's Brussels I Regulation establishes compulsory jurisdiction in national courts over civil and commercial lawsuits concerning companies and persons domiciled in an EU Member State, which enables victims of rights abuses abroad to bring civil cases against EU-based companies in their home countries. ${ }^{135}$

The OPSC obligates States parties to establish jurisdiction for offences related to the sale of children, child prostitution and child pornography that have been committed abroad where victims or offenders are citizens or residents. The Protocol further mandates that governments extend liability for these offences to legal persons, and requires that child victims have access to procedures to seek compensation from those responsible. ${ }^{136}$

Statutes of limitation and similar laws require that legal claims be filed within a set period of time following the abuse in question. Many children lack the knowledge and means to pursue claims within these time periods, and are dependent on the interest and understanding of adult representatives.
Extend deadlines for bringing cases related to rights abuses that occur during childhood such that time periods do not begin running until children reach the age of majority. 


\section{Safety and protection}

Length of proceedings

\section{Corruption}

\subsection{Non-judicial mechanisms}

While remedies and accountability for the most serious children's rights abuses must be addressed in the courts, effective remedies for some infringements may also be provided through non-judicial mechanisms. Governments can offer and support a wide array of these mechanisms to suit differing needs and circumstances, and businesses may also directly operate their own grievance mechanisms.

Regardless of their nature, all non-judicial mechanisms should meet standards of accessibility, independence, impartiality, procedural fairness and enforceability, and should not preclude children from later pursuing cases through the courts. Indeed, it is important to note that while non-judicial mechanisms can serve to complement judicial mechanisms in providing access to a remedy for children's rights infringements, they should never be viewed as a substitute for the often stronger powers and mandate of judicial mechanisms.
Bringing cases against businesses that hold power and influence within the community may put child complainants at risk of harassment reprisal, revictimization and social stigma.

As a result, children and their representatives may be reluctant to publicly identify themselves in order to state their claims.

Complicated fact patterns, heavy caseloads, and extensive backlogs often mean long waits for children's claims to reach the courtroom. Delays may allow rights abuses to continue, and drawnout proceedings are particularly difficult for children to follow and pursue given their unique sense of timing. Businesses, however, are in most instances better equipped to manage lengthy cases, and may even take steps to actively postpone their resolution where this works to financial advantage.

Bribery and other forms of corruption allow those in positions of economic advantage to unduly influence judicial authorities to make decisions in their favour. Where businesses are able to purchase or negotiate special access to the judiciary, child complainants are likely to face biased decision makers unwilling to rule in their favour.
Following the principles of child friendly justice, ${ }^{137}$ put appropriate safeguards in place to protect child complainants and their representatives throughout their involvement in legal proceedings.

As recommended above, permit third parties such as non NHRIs to submit complaints on behalf of children.

Prioritize legal proceedings involving children within the justice system, and ensure the timely provision of remedies.

Enable the application of provisional measures to address continuing infringements of children's rights while proceedings remain ongoing.

Take all measures necessary to ensure the independence of the judiciary, including the transparent appointment of judges based on professional competence, the adoption and enforcement of clear codes of judicial ethics, and the provision of sufficient remuneration and secure tenure. governmental organizations and 
Effectiveness Criteria

\section{Box 49}

\section{for Non-Judicial Mechanisms}

To provide an effective remedy for infringements of children's rights, non-judicial mechanisms should:

- Have clear rules for admitting and reviewing cases;

- Provide for independent and impartial decision makers;

- Follow fundamental principles of due process and procedural fairness;

- Be accessible to children and support their participation throughout proceedings;

- Offer fair, prompt and enforceable measures of redress;

- Be subject to judicial review/appeal;

- Never prevent children from pursuing judicial remedies.
Several non-judicial mechanisms are described in further detail below. In view of these and other options, governments should engage with children, communities, civil society organizations and businesses to ensure that children and their representatives understand the full range of non-judicial mechanisms available to provide redress. Governments should provide complete and accurate information about the processes entailed and possible outcomes, and support children in accessing the legal or other assistance necessary to direct and pursue their claims.

\section{Administrative mechanisms}

“...Agencies with oversight powers relevant to children's rights, including labour, education and health and safety inspectorates, environmental tribunals, taxation authorities...and bodies focusing on equality in the business sector can also play a role in the provision of remedies. These agencies can proactively investigate and monitor abuses and may also have regulatory powers allowing them to impose administrative sanctions on businesses which infringe on children's rights." -General Comment no. 16, para. 30

Governments should grant agencies, inspectorates and other administrative bodies with oversight powers the authority to receive complaints about business-related breaches of relevant rules and regulations, including in the areas of health, safety, labour, education and the environment. This serves to protect the specific interests of children, employees, consumers, and other groups, as well as general public goods like clean water and air. Administrative bodies can also be mandated to monitor and investigate potential rights abuses of their own initiative and, where infringements are found, be given powers to impose administrative sanctions on responsible parties. 
"... [N]ational human rights institutions can be involved, for example, in receiving, investigating and mediating complaints of violations... Where necessary, States should broaden the legislative mandate of national human rights institutions to accommodate children's rights and business." -General Comment no. 16, para. 76

The Committee on the Rights of the Child has urged States to give NHRIs and children's ombudspersons the authority to receive individual complaints from or on behalf of children, including allegations involving business-related violations or infringements. ${ }^{139} \mathrm{NHRIs}$ and children's ombudspersons must be given the means and authority to enforce their decisions, and their recommendations should be considered binding. These institutions may further be empowered to investigate serious or widespread abuses of their own accord; to refer complaints to the judiciary, the police or the public prosecutor as appropriate; to represent child complainants in judicial proceedings; and even to bring cases against responsible parties directly in the courts.

\section{NHRI Complaint Mechanisms}

\section{Box 51}

The ICC's Edinburgh Declaration gives guidance to NHRIs on addressing complaints related to business and human rights, and encourages NHRIs to engage in:

"I. Promoting within the community and the business sector an awareness of their respective roles in monitoring and receiving complaints of human rights violations by business entities, as well as other remedies;

II. Handling complaints related to corporate human right abuse using their quasi judicial powers, including through conciliation, mediation, and making recommendations or orders to improve the situation;

III. Co-operating in the development of a database on the regulatory framework and remedies available in their respective jurisdictions;

IV. Utilising their complaints mechanisms, and the outcomes of complaints and inquiries, to monitor on-going practices of business entities;

V. Working closely with the judiciary to promote access to justice, and handling cases related to public interest litigation." ${ }^{140}$

The Ombudsperson for Children in Mauritius received numerous complaints regarding an advertisement from a mobile network operating company encouraging young people to meet for romantic encounters. Highlighting concerns related to the service's potential to facilitate child sexual abuse and exploitation, the Ombudsman referred the case to relevant ministries within the government. The government found a need for increased public awareness on child online protection, and the company took measures to mitigate any possible support for children's rights abuses. ${ }^{141}$

In terms of mediation and assistance to victims, the Declaration further suggests that NHRIs:

"Mediate between enterprises, trade unions, governments and victims of business related abuse;

Assist the victims of business-related abuse to seek redress and compensation;

Refer cases to the domestic jurisdiction for follow-up."142

In 2011, the National Commission for the Protection of Child Rights in India filed a police report identifying a mine where children were found to be employed. ${ }^{143}$

It is critical that complaints mechanisms offered by children's ombudspersons and NHRIs be accessible to children. Fees should never be charged, and complaints should be accepted through multiple means including in writing, online, over the telephone and in person. States should also widely disseminate accessible, child-friendly information on complaints mechanisms, and actively support children in using these.

139 Committee on the Rights of the Child, General Comment no. 2, The role of independent national human rights institutions in the promotion and protection of the rights of the child, UN Doc. CRC/C/GC/2, 15 November 2002, paras. 13-14.

140 International Co-Ordinating Committee of National Institutions for the Promotion and Protection of Human Rights, The Edinburgh Declaration, 10 October 2010, para. 13, Part C - Complaints Handling and Part D - Mediation and Conciliation.

141Mauritius, Ombudsperson for Children, case OCO/COMP/11/2278, <http://oco.gov.mu/English/Documents/report2010/chap9.pdf>, accessed 24 October 2014

142 International Co-Ordinating Committee of National Institutions for the Promotion and Protection of Human Rights, The Edinburgh Declaration, 10 October 2010, para. 13, Part C - Complaints Handling and Part D - Mediation and Conciliation.

143 Sedletzki, Vanessa, Championing Children's Rights: A global study of independent human rights institutions for children - Summary Report, 2012, p. 13. 


\section{Powers of Investigation}

The powers of investigation that children's ombudspersons and NHRIs have are crucial to their ability to offer an effective remedy. Among other things, these institutions may be given the authority to order the production of evidence, summon witnesses, and enter private property to substantiate allegations or bring a halt to abuses. In Jamaica, for example, the Office of the Children's Advocate can require government officials and members of the public to provide information or appear in person to answer questions related to a case. ${ }^{144}$ The $\mathrm{NHRI}$ in Colombia may enter public or private premises to investigate a complaint or prevent a rights violation, and the Ombudsperson for Children in Mauritius has the general authority to enter any premises where a child is present. ${ }^{145}$
Alternative dispute resolution mechanisms: arbitration, mediation, conciliation

“Non-judicial mechanisms, such as mediation, conciliation and arbitration, can be useful alternatives for resolving disputes concerning children and enterprises. They must be available without prejudice to the right to judicial remedy. Such mechanisms can play an important role alongside judicial processes, provided they are in conformity with the Convention and the Optional Protocols thereto and with international principles and standards of effectiveness, promptness and due process and fairness."

\section{-General Comment no. 16, para. 71}

Alternative mechanisms for dispute resolution such as mediation, conciliation or arbitration can also be useful in addressing business-related abuses of children's rights. Arbitration uses quasi judicial procedures and tribunals to resolve cases outside the courtroom, while mediation and conciliation offer less formal procedures to the same effect. These processes can be more accessible than formal justice mechanisms and provide quick, relatively inexpensive and culturally relevant remedies. In addition, alternative mechanisms can create space for discussing the broader aspects and implications of negative business impacts. For instance, community displacement may not only result in lost earnings and interruption in health and educational services, but also bring about significant changes in cost of living and reduce access to important religious or cultural sites.

At the same time, alternative dispute resolution mechanisms may prove inaccessible to child complainants or fail to adequately account for power imbalances between children and companies. Children must always retain recourse to the courts to enforce their rights, and individual case outcomes should be both reviewable and enforceable through the judicial system wherever necessary to guarantee the effectiveness of the remedy provided. Even with these protections in place, however, the confidential nature of decisions made and agreements reached through alternative processes may mean that companies have little incentive to address systemic or ongoing risks to children's rights once the case at hand has been resolved.

With this in mind, governments should take steps to ensure that businesses and affected children and communities have the knowledge, understanding, skills and capacity to fully engage in alternative dispute resolution as a means to holistically address children's rights abuses. Arbitrators and mediators should be trained in children's rights and able to support children's participation in relevant processes, and governments should encourage children, businesses, civil society organizations and dispute resolution experts to share their experiences with a view to developing best practices. 


OECD National Contact
Points
The Organisation for Economic Co-operation and
Development's (OECD) Guidelines for Multinational
Enterprises have established a mechanism for
resolving disputes with companies that fail to
comply with the Guidelines. Within adhering
States, ${ }^{146}$ governments maintain 'national contact
points' to promote the Guidelines and review
specific instances where a business has breached
these. Any interested person or group can file a
complaint, and national contact points are then
tasked with investigating the allegations, bringing
the parties together to seek resolution, and offering
final recommendations. The decisions of national
contact points are not binding, however, and
participation in complaints mechanism processes
is strictly voluntary. ${ }^{147}$

“...Grievance mechanisms established by business enterprises can provide flexible and timely solutions and at times it may be in a child's best interests for concerns raised about a company's conduct to be resolved through them. These mechanisms should follow criteria that include: accessibility, legitimacy, predictability, equitability, rights compatibility, transparency, continuous learning and dialogue. In all cases, access to courts or judicial review of administrative remedies and other procedures should be available."

-General Comment no. 16, para. 71

Businesses may establish grievance mechanisms to directly respond to the concerns of individuals and communities affected by their activities. These can be operated on company wide and site or project-based levels, and may be integrated within existing corporate functions or run separately with third-party oversight. Regardless of their precise scope and nature, all company grievance mechanisms should be accessible, legitimate, equitable, compatible with the victim's rights, transparent, predictable in their outcomes, and based on continuous learning and dialogue. ${ }^{148}$ Children should be able to meaningfully participate in dialogues at every stage of the process, and particular attention should be given to their rights to privacy, information and protection.

Governments may wish to encourage or incentivize businesses to maintain grievance mechanisms, and may require that businesses publicly report on their existence and functionality. Governments might also give guidance on designing rights-compatible procedures, or provide exemplary case studies to demonstrate how these can both address abuses and prevent potential negative impacts. Importantly, however, company grievance mechanisms are not a substitute for governments' obligation to provide remedies for violations or abuses of children's rights, and should never be permitted to obstruct access to judicial proceedings.

\subsection{International and Regional mechanisms}

\footnotetext{
"States should make every effort to facilitate access to international and regional human rights mechanisms, including the Optional Protocol to the Convention on the Rights of the Child on a communications procedure, so that an individual child or a group of children, or others acting on his/her/their behalf, are able to obtain remedy for State failure to adequately respect, protect and fulfil children's rights in relation to business activities and operations."

-General Comment no. 16, para. 72
}

When States fail to provide effective national remedies for violations, children should be able to seek redress through international or regional human rights mechanisms. While regional and international complaints cannot be brought directly against businesses, children can use these mechanisms to hold public authorities accountable for failing to meet their obligations to protect against abuses by businesses.

As a first measure, States should ratify the relevant regional and international human rights treaties under which complaints mechanisms operate and recognize the authority of these mechanisms to hear matters that implicate them. Governments should support and facilitate children's access to any international and regional complaints mechanisms, and must commit to implementing decisions and recommendations to their fullest extent. 


\section{International Mechanisms}

A number of United Nations human rights instruments establish treaty bodies with the power to receive complaints against ratifying governments for failing to protect against or remedy rights infringements, including the Human Rights Committee, the Committee on Economic, Social and Cultural Rights, the Committee on the Elimination of Racial Discrimination, the Committee on the Elimination of Discrimination against Women, the Committee against Torture, the Committee on the Rights of Persons with Disabilities, the Committee on Enforced Disappearances and, most recently, the Committee on the Rights of the Child. ${ }^{149}$

The proceedings before these Committees are quasijudicial, and, where violations are found, result in a series of targeted recommendations. While not strictly enforceable, governments are expected to implement these in good faith and in a timely manner. ${ }^{150}$

\section{Regional Mechanisms}

The European Court of Human Rights, the InterAmerican Court of Human Rights and the African Court on Human and Peoples' Rights offer avenues of judicial redress for human rights violations. Complaints must allege breaches of treaty obligations, and may be brought against States for failing to protect against or remedy rights abuses by private actors, including businesses. Final court judgments are binding, and may order that governments provide multiple forms of redress including compensation.

Although less formal, the European Committee of Social Rights, the Inter American Commission on Human Rights, the African Commission on Human and Peoples' Rights and the African Committee of Experts on the Rights and Welfare of the Child can also receive complaints against governments for the failure to prevent or remedy business-related violations of children's rights.

149 The individual complaints mechanisms for the Committee on Migrant Workers has not yet entered into force.

150 To see relevant information on the applicable rules for treaty body complaints procedures, consult Office of High Commissioner for Human Rights, Human Rights Bodies - Complaints Procedures, <www.ohchr.org/EN/HRBodies/TBPetitions/Pages/HRTBPetitions.aspx>, accessed 5 January 2015 . 


\section{International and Regional mechanisms}

\section{CRC Complaints Mechanism}

\section{Box 54a}

The OPIC, adopted in 2011, empowers the Committee on the Rights of the Child to review violations of children's rights brought to its attention. Children and their representatives may submit individual complaints against ratifying States; the Committee may conduct inquiries into allegations of grave or systemic violations; and States may draw attention to violations of children's rights occurring in other States parties. Through this mechanism, governments may be held responsible for business-related children's rights abuses they have failed to sufficiently protect against, and are similarly liable for causing or contributing to rights violations through their own business activities. Governments are strongly encouraged to ratify or accede to the OPIC, and thereby provide children with access to an international mechanism able to review and remedy violations of their rights under the CRC, OPAC and OPSC.

\section{Inter-American Commission on Human Rights:}

\section{Box 54b} La Oroya Case

A group of civil society organizations filed a series of petitions with the Inter-American Commission on Human Rights on behalf of 65 persons, including 33 children, in the smelting town of La Oroya, Peru. Residents of the town had long suffered serious health problems from dangerously high levels of industrial pollution, and sought to hold the Peruvian government responsible for failing to protect them from the ill effects of environmental contamination in violation of their rights to life and physical integrity, and of children's rights as set out in the American Convention on Human Rights. ${ }^{151}$ The Commission requested that the Peruvian government provide the victims with immediate medical assistance, noting the particularly harmful impacts on children, and remarked on possible rights violations. ${ }^{152}$

\section{European Committee of Social Rights:}

Box 54c

\section{Child Labour in Portugal}

In its first ever case, the European Committee of Social Rights found Portugal in violation of the European Social Charter (ESC) for failing to protect against child labour. The Committee emphasized that child labour encompasses all paid and unpaid work by any child in any economic sector for any enterprise, including family businesses, and that only "light work" may be authorized for children as defined in national law. While the Committee welcomed Portugal's strict legislation, it observed that several thousand children were nonetheless engaged in unlawful child labour. As such, the Committee underscored Portugal's obligation to ensure the effective application and rigorous supervision of its laws to protect children and young people from harmful labour. ${ }^{153}$

151 See American Convention on Human Rights, art. 19

152 Inter-American Commission on Human Rights, Precautionary Measures, Community of La Oroya, 31 August 2007, <www.cidh.org/medidas/2007. eng.htm>, accessed 24 October 2014

153 European Committee of Social Rights, International Commission of Jurists v. Portugal, Complaint No. 1/1998, 9 September 1999, <www.coe.int/t/ $\mathrm{dghl} /$ monitoring/socialcharter/Complaints/CC1Merits_en.pdf>, accessed 5 January 2015. 


\subsection{Reparations}

"When determining the level or form of reparation, mechanisms should take into account that children can be more vulnerable to the effects of abuse of their rights than adults and that the effects can be irreversible and result in lifelong damage. They should also take into account the evolving nature of children's development and capacities and reparation should be timely to limit ongoing and future damage to the child or children affected... States should provide medical and psychological assistance, legal support and measures of rehabilitation to children who are victims of abuse and violence caused or contributed to by business actors. They should also guarantee non-recurrence of abuse through, for example, reform of relevant law and policy and their application, including prosecution and sanction of the business actors concerned."

-General Comment no. 16, para. 31

Adequate reparations are essential to effective remedies, and case outcomes should serve to restore children's rights as far as possible. Under international human rights law, reparations may take five forms: restitution, compensation, satisfaction, rehabilitation, and guarantees of non repetition. ${ }^{154}$ Thus, reparations for children's rights abuses can look beyond monetary compensation and include additional measures to promote children's recovery and reintegration in an environment that fosters their health, self-respect and dignity. ${ }^{155}$ As such, governments should identify and ensure the availability of recovery services that are adequately resourced and sufficiently specialized to account for the individual needs and interests of children whose rights have been infringed.

As children are especially vulnerable to negative business impacts, including in the workplace, the marketplace, the environment and the community, reparations for business-related violations should be tailored to specifically address any particular effects on children. Reparations should be made available promptly after the resolution of a legal claim or complaint, and should address both the immediate and potential long-term effects of violations. Governments should also take steps to guarantee that the same violations do not occur again, both undertaking reforms to applicable laws and policies and improving enforcement to increase accountability for businesses that fail to respect children's rights.

154 See Basic Principles and Guidelines on the Rights to Remedy for Victims of Gross Violations of International Human Rights Law and Serious Violations of International Humanitarian Law, Principle IX, United Nations General Assembly Resolution 60/147, 16 December 2005.

155 See CRC, art. 39 


\section{AFTERWORD}

Reading this guide makes clear that there are often no simple, fast or one-size-fits-all ways for governments to realize children's rights with regard to business activities, operations and relationships. The obligations are many, and the actors, topics and issues addressed are complex, diverse and ever evolving. This guide could not and does not aspire to cover every aspect of children's rights and business, nor does it purport to offer ideal solutions for every situation.

Nonetheless, this guide must not be viewed as a mere catalogue of difficulties and challenges. Rather, it should be seen as an inspiration for every State to approach children's rights and business with the practical wisdom of GC 16. Governments have already made powerful commitments to international children's rights. It is now hoped that this guide, much like GC 16 itself, contributes to greater respect, protection and fulfilment of the rights of all the world's children. 


\section{RESOURCES}

\section{PART ONE - INTRODUCTION}

Gerber, Paula, Joanna Kyriakakis and Kate O'Byrne, General Comment 16 on State Obligations Regarding the Impact of the Business Sector on Children's Rights: What is its Standing, Meaning and Effect, Melbourne Journal of International Law, 2013, Vol. 14, <www.law.unimelb.edu.au/files/dmfile/04Gerber1.pdf>, accessed 8 October 2014.

United Nations Children's Fund, Children are everyone's business. A practical workbook to help companies understand and address their impact on children's rights. Pilot workbook, UNICEF, <www.unicef.org/csr/css/Workbook_A4_LR_ low_res.pdf>, accessed 20 October 2014.

United Nations Children's Fund, Children are everyone's business: workbook 2.0. A guide for integrating children's rights into policies, impact assessments and sustainability reporting. Second edition, UNICEF, August 2014, <WWW.unicef.org/ csr/css/Workbook_2.0_Second_Edition_29092014_LR.pdf>, accessed 20 October 2014.

United Nations Children's Fund, Implementation Handbook for the Convention on the Rights of the Child, Fully revised third edition, UNICEF, Geneva, 2007, <WWW.unicef.org/publications/index_43110.html>, accessed 8 October 2014.

United Nations Commission on Human Rights, Human Rights Resolutions 2005/69, Human Rights and transnational corporations and other business enterprises, UN Doc. E/CN.4/RES/2005/69, 20 April 2005.

United Nations Human Rights Council, Resolution 26/9, Elaboration of an international legally binding instrument on transnational corporations and other business enterprises with respect to human rights, UN Doc. A/HRC/RES/26/9, 26 June 2014

United Nations Human Rights Council, Human rights and transnational corporations and other business enterprises, UN Doc. A/HRC/RES/17/4.

United Nations Human Rights Council, UN Guiding Principles on Business and Human Rights: Implementing the United Nations 'Protect, Respect and Remedy' Framework, Report of the Special Representative of the Secretary-General on the issue of human rights and transnational corporations and other business enterprises, John Ruggie, UN Doc. A/ $\mathrm{HRC} / 17 / 31,21$ March 2011.

\section{Websites}

United Nations Children's Fund, United Nations Global Compact and Save the Children, Children's Rights and Businesses Principles, <http://childrenandbusiness.org>, accessed 8 October 2014.

United Nations Treaty Collection, Status of the Convention on the Rights of the Child, <https://reaties.un.org/Pages/ ViewDetails.aspx?src=TREATY\&mtdsg_no=IV-11\&chapter=4\&lang=en>, accessed 8 October 2014.

United Nations Treaty Collection, Status of the Optional Protocol to the Convention on the Rights of the Child on the sale of children, child prostitution and child pornography, $<$ https://treaties.un.org/pages/ViewDetails.aspx?src=TREATY\&mtdsg_ no $=\mid \mathrm{V}-11-\mathrm{c} \&$ chapter $=4$ \&lang $=\mathrm{en}>$, accessed 8 January 2015.

United Nations Treaty Collection, Status of the Optional Protocol to the Convention on the Rights of the Child on the involvement of children in armed conflict, <https://treaties.un.org/pages/ViewDetails.aspx?src=TREATY\&mtdsg_no=IV11 -b\&chapter $=4$ \&lang=en>, accessed 8 January 2015.

United Nations Treaty Collection, Status of the Optional Protocol to the Convention on the Rights of the Child on a communications procedure, <https://treaties.un.org/pages/ViewDetails.aspx?src=TREATY\&mtdsg_no=IV-11d\&chapter=4\&lang=en>, accessed 8 January 2015.

Committee on the Rights of the Child, General Comments, <http://tbinternet.ohchr.org/_layouts/treatybodyexternal/ TBSearch.aspx? Lang=en\&TreatyID=5\&DocTypeID=11>, accessed 22 December 2014 


\section{PART TWO - STATE OBLIGATIONS ON BUSINESS AND CHILDREN'S RIGHTS}

Abramson, Bruce, "Article 2. The Right to Non-Discrimination" in A. Alen et al. (Eds.) A Commentary to the United Nations Convention on the Rights of the Child, Martinus Nijhoff Publishers, Leiden, 2008.

Committee on Economic, Social and Cultural Rights, General Comment no.12: The right to adequate food (art. 11), UN Doc. E/C.12/1999/5, 12 May 1999.

Committee on Economic, Social and Cultural Rights, General Comment no. 13: The Right to Education (art. 13 of the Covenant), E/C.12/1999/10, 8 December 1999.

Committee on Economic, Social and Cultural Rights, General Comment no. 3: The nature of States parties' obligations (art. 2, para.1, of the Covenant), contained in UN Doc. E/1991/23.

Committee on the Rights of the Child, General Comment no. 5, General Measures of implementation of the Convention on the Rights of the Child (arts. 4, 42, and 44 para. 6), UN Doc. CC/GC/2003/5, 27 November 2003.

Committee on the Rights of the Child, General Comment no. 6, Treatment of Unaccompanied and Separated Children Outside their Country of Origin, UN Doc. CRC/C/GC/2005/6, 1 September 2005.

International Commission of Jurists, Financial Institutions and the Rights of the Child, An Overview of Policies and Accountability Mechanisms, ICJ, Geneva, 2014.

Office of the High Commissioner for Human Rights, Legislative History of the Convention on the Rights of the Child, Part. I, United Nations, New York and Geneva, 2007, <www.ohchr.org/Documents/Publications/LegislativeHistorycrclen. pdf>, accessed 9 October 2014.

Plan International, United Nations Special Representative of the Secretary General on Violence Against Children, Protecting children from harmful practices in plural legal systems - with special emphasis on Africa, New York, 2012, <http:// srsg.violenceagainstchildren.org/sites/default/files/publications_final/SRSG_Plan_harmful_practices_report_final.pdf>, accessed 9 October 2014.

Rishmawi, Mervat, "Article 4: the Nature of States Parties' Obligations", in A. Alen et al. (Eds.) A Commentary to the United Nations Convention on the Rights of the Child, Martinus Nijhoff Publishers, Leiden, 2006.

United Nations Children's Fund, Implementation Handbook for the Convention on the Rights of the Child, Fully revised third edition, UNICEF, Geneva, 2007, <www.unicef.org/publications/index_43110.html>, accessed 9 October 2014.

United Nations Children's Fund, Protecting the World's Children, Impact on the convention on the Rights of the Child in Diverse Legal Systems, Cambridge University Press, New York, 2007.

Report of the Special Rapporteur on the sale of children, child prostitution and child pornography, Najat Maalla M'jid Addendum, Mission to Honduras, UN Doc. A/HRC/22/54/Add.2, 21 January 2013.

Working Group on the issue of human rights and transnational corporations and other business enterprises, Statement on the implications of the Guiding Principles on Business and Human Rights in the context of Israeli settlements in the Occupied Palestinian Territory, 6 June 2014, <www.ohchr.org/Documents/Issues/Business/OPTStatement6June2014. pdf>, accessed 22 October 2014.

World Health Organization, A framework for implementing the set of recommendations on the marketing of foods and non-alcoholic beverages to children, WHO, Switzerland, 2012, <http://apps.who.int/iris/ bitstream/10665/80148/1/9789241503242_eng.pdf?ua=1>, accessed 22 October 2014.

\section{Websites}

Danish Consumer Ombudsman, Children, Young People and Marketing Practices, <www.consumerombudsman. dk/?SC_itemid=801ff5ab-c774-4529-8a41-d6e933cd13b0\#>, accessed 17 October 2014.

EKF, 2013 CSR Report, <www.ekf.dk/Docs/EKF\%20CSR\%202013\%20-\%20Final.pdf>, accessed 17 October 2013.

European Commission, Trade and Development Partnership with the Caribbean Region, <http://ec.europa.eu/trade/ policy/countries-and-regions/regions/caribbean>, accessed 19 October 2014. 
Finnish Government, National Action Plan on Business and Human Rights, Government covering note on the UN Guiding Principles on Business and Human Rights National Action Plan, <www.tem.fi/files/41214/TEMjul_46_2014_web_ EN_21102014.pdf>, accessed 19 January 2015.

Maastricht Principles on Extraterritorial Obligations of States in the area of Economic, Social and Cultural Rights, 2012, $<$ WWw.fian.org/fileadmin/media/publications/2012.02.29_-_Maastricht_Principles_on_Extraterritorial_Obligations. pdf>, accessed 9 October 2014 .

Norges Bank Investment Management, Responsible Investments, Children's Rights, <www.nbim.no/en/responsibility/ responisble-investments/childrens-rights>, accessed 19 October 2014.

Swedish Broadcasting Authority, Radio and Television Act, Ministry of Culture, Sweden, 2010, <www.radioochtv.se/ documents/styrdokument/radio\%20and\%20television\%20act.pdf>, accessed 3 November 2014.

Switzerland, Federal Law on the provision of private security services abroad, of 27 September 2013, <www.admin.ch/ opc/fr/federal-gazette/2013/6577.pdf>, accessed 9 October 2014.

UK Trade and Investment, Overseas Business Risk - Israel, 3 December 2013, <http://webarchive.nationalarchives.gov. uk/20140403154217/http://ukti.gov.uk/gb_gb/uktihome/premiumcontent/107322.html?null>, accessed 3 November 2014.

WHO, Global Database on the implementation of Nutrition Action (GINA): El Salvador, Ley de Promocción, Protección y Apoyo a la Lactancia Materna (Decreto No. 404), <https://extranet.who.int/nutrition/gina/sites/default/files/SLV\%20 $2013 \% 20$ Ley\%20de\%20Promocion\%2C\%20Protection\%20y\%20Apoyo\%20a\%20la\%20Lactancia\%20Materna_0. pdf>, accessed 17 October 2014.

\section{Concluding Observations of the Committee on the Rights of the Child}

Concluding Observation to Canada, UN Doc. CRC/C/CAN/CO/3-4, 6 December 2012.

Concluding Observations to Argentina, UN Doc. CRC/C/ARG/CO/3-4, 11 June 2010.

Concluding Observations to Ecuador, UN Doc. CRC/C/ 15/Add.262, 13 September 2005.

Concluding Observations to Ecuador, UN Doc. CRC/C/ECU/CO/4, 29 January 2010.

Concluding Observations to Finland, UN Doc. CRC/C/FIN/CO/4, 20 June 2011.

Concluding Observations to Guatemala, UN Doc. CRC/C/GTM/CO/3-4, 1 October 2010.

Concluding Observations to Mozambique, UN Doc. CRC/C/MOZ/CO/2, 29 September 2009.

Concluding Observations to Nicaragua, UN Doc. CRC/C/NIC/CO/4, 1 October 2010.

Concluding Observations to Thailand, UN Doc. CRC/C/OPSC/THA/CO/1, 21 February 2012. 


\section{PART THREE - STRATEGIES AND TOOLS TO REGULATE AND INFLUENCE BUSINESS}

\section{Legislation and regulation}

Committee on the Rights of the Child, General Comment no. 5, General Measures of implementation of the Convention on the Rights of the Child (arts. 4, 42, and 44, para. 6), UN Doc. CRC/GC/2003/5, 27 November 2003.

Committee on the Rights of the Child, General Comment no. 14 (2013) on the right of the child to have his or her best interests taken as a primary consideration (art. 3, para. 1), UN Doc. CRC/C/GC14, 29 May 2013.

De Schutter, Olivier et al., Human Rights Due Diligence: The Role of States, International Corporate Accountability Roundtable, December 2012, <http://accountabilityroundtable.org/analysis/hrdd>, accessed 21 October 2014.

European Commission, United Nations Children's Fund, Child Rights Toolkit: Integrating Child Rights in Development Cooperation, Module 5 - Child Impact Assessment, 2014, UNICEF, 2014, <www.unicef.org/eu/crtoolkit/toolkit-module5. html>, accessed 31 May 2014.

FAO, GTZ, Right to Food - Putting it into Practice, 2006, Rome, <www.fao.org/ag/agn/nutrition/docs/brief\%2005_ nutrition_en.pdf>, accessed 13 October 2014.

Foresti, Marta, Helen Baños Smith and Harry Jones, Towards a Suite of Tools for Ex Ante Child Rights Impact Assessment Concept Note for UNICEF, ODI, August 2009, <wWw.redxlasalud.org/index.php/mod.documentos/mem.descargar/ fichero.DOC-46\%232E\%23pdf>, accessed 21 October 2014.

Office of the High Commissioner for Human Rights, The Corporate Responsibility to Respect Human Rights: An Interpretive Guide, United Nations, New York and Geneva, 2012, <www.ohchr.org/Documents/Issues/Business/ RtRInterpretativeGuide.pdf>, accessed 31 May 2014.

Uptake of the Guiding Principles on Business and Human Rights: practices and results from pilot surveys of Governments and corporations, Addendum to the Report of the Working Group on the issue of human rights and transnational corporations and other business enterprise, UN Doc. A/HRC/23/32/Add.2, 16 April 2013.

Save the Children, Child Rights Governance Analysis Tool, Save the Children, 2012, <http://resourcecentre.savethechildren. se/sites/default/files/documents/6152.pdf>, accessed 19 May 2014.

Schydlowsky, Daniel M. and Robert C. Thompson, Reducing the Financial Risk of Social Conflict, in Americas Quarterly, Spring 2014, <wWw.americasquarterly.org/content/reducing-financial-risk-social-conflict>, accessed 23 October 2014.

Sylvander, Louise, Child ImpactAssessments, MinistryofHealthandSocialAffairs Sweden, MinistryofForeignAffairs Sweden, January 2001, <wWw.manskligarattigheter.se/dm3/file_archive/020523/d18c33283b29d7cbb15d9bb65d1db726/ barn\%20Child\%20Impact\%20Assessments.pdf>, accessed 13 October 2014.

Taylor, Mark B., Human Rights Due Diligence: The Role of States, 2013 Progress Report, ICAR, 2013, <http:// accountabilityroundtable.org/wp-content/uploads/2013/11/ICAR-Human-Rights-Due-Diligence-2013-Update-FINAL. pdf>, accessed 23 October 2014.

Tisdall, Johnathan, NORWAY: Norwegian consumers sounds off on food and health, Just-food, 5 April 2005, <www. just-food.com/news/norwegian-consumers-sound-off-on-food-and-health_id84097.aspx>, accessed 13 October 2014.

UNICEF Canada, Child Rights Impact Assessment: A Tool to Focus on Children, May 2013, <www.unicef.ca/sites/ default/files/imce_uploads/report_from_cria_symposium_may2013_canada.pdf>, accessed 31 May 2014.

United Nations Children's Fund, Children are Everyone's Business A practical workbook to help companies understand and address their impact on children's rights, Pilot workbook, UNICEF, <WwW.unicef.org/csr/css/Workbook_A4_LR_ low_res.pdf>, accessed 21 October 2014.

United Nations Children's Fund, United Nations Global Compact and Save the Children, Children's Rights and Businesses Principles, <http://childrenandbusiness.org>, accessed 21 October 2014.

United Nations Human Rights Council, UN Guiding Principles on Business and Human Rights: Implementing the United Nations 'Protect, Respect and Remedy' Framework, Report of the Special Representative of the Secretary-General 
on the issue of human rights and transnational corporations and other business enterprises, John Ruggie, UN Doc. A/ HRC/17/31, 21 March 2011

\section{Websites}

Committee of Foreign Affairs, Motion: Mise en œuvre du rapport de droit comparé du Conseil fédéral sur la responsabilité des entreprises en matière de droits humains et d'environnement, 1 September 2014, <www.parlament.ch/e/suche/ Pages/geschaefte.aspx?gesch_id=20143671>, accessed 21 October 2014.

Corporate Social Responsibility in Sweden, <https://sweden.se/business/csr-in-sweden>, accessed 16 October 2014.

Danish Business Authority, Legislation, <http://csrgov.dk/legislation>, accessed 22 October 2014.

European Commission, Disclosure of non-financial information: Europe's largest companies to be more transparent on social and environmental issues, Statement/14/291, 29 September 2014, <http://europa.eu/rapid/press-release_ STATEMENT-14-291_en.htm>, accessed 23 October 2014.

France, Assemblée Nationale, $N^{\circ} 2578$ - Proposition de loi relative au devoir de vigilance des sociétés mères et des entreprises donneuses d'ordre, Enregistré à la Présidence de l'Assemblée nationale, 11 February 2015, <www. assemblee-nationale.fr/14/propositions/pion2578.asp>, accessed 18 March 2015.

Italian Ministry of Economic Development, Cyberbullismo: online il Codice di Autoregolamentazione, <www. sviluppoeconomico.gov.it/index.php?option =com_content\&view $=$ article\&viewType $=1 \&$ idarea1 $=593 \&$ idarea $2=0$ \&idar ea3=0 \&idarea4=0 \&andor $=$ AND \& sectionid $=0$ \&andorcat $=$ AND \& partebassaType $=0$ \&idareaCalendario $1=0$ \&MvediT $=1$ \&showMenu=1\&showCat=1\&showArchiveNewsBotton>, accessed 16 October 2014.

KEKI, Evaluating the Child and Youth Impact Report in Flanders - Executive Summary, <www.google.ch/url?sa=t\&rct= $j \& q=\& e s r c=s \& s o u r c e=w e b \& c d=1 \& c a d=r j a \& u a c t=8 \& v e d=0 C C l O F j A A \& u r l=h t t p \% 3 A \% 2 F \% 2 F w w w . k e k i . b e \% 2 F d o$ cuments\%2F2012_11_15\%2520joker\%2520evaluation_executive\%2520summary.docx\&ei=5d47VLLVBcL2aJTEgKgH \&usg=AFQjCNEhOwOnpaYM4NWAS6AKAmWsjtPzPg\&bvm=bv.77161500,d.bGQ>, accessed 13 October 2014.

Swiss Campaign for Corporate Justice, Global Business? Global Responsibility, 20 April 2015, <www.corporatejustice. ch/en/>, accessed 24 April 2015.

The Code, The Code of Conduct for the Protection of Children from Sexual Exploitation in Travel and Tourism, <www. thecode.org>, accessed 23 October 2014.

United States of America, California Transparency in Supply Chains Act, Civil Code para. 1714.43 (2012), <www.leginfo. ca.gov/cgi-bin/displaycode?section =civ\&group=01001-02000\&file=1708-1725>, accessed 3 November 2014 .

United States of America, Executive Order - Strengthening Protection against Trafficking in Persons in Federal Contracts, 25 September 2012, <www.whitehouse.gov/the-press-office/2012/09/25/executive-order-strengthening-protectionsagainst-trafficking-persons-fe>, accessed 22 October 2014.

Welsh Government, Children's Rights Scheme 2014, <http://wales.gov.uk/docs/dsjlg/publications/cyp/140501childrens-rights-scheme-2014-en.pdf>, accessed 13 October 2014.

Welsh Government, Minerals Technical Advice Note 2: Coal (2009), <http://wales.gov.uk/docs/desh/ policy/090120coalmtanen.pdf>, accessed 14 January 2015.

WHO, The International Code of Marketing of Breast-milk Substitutes, <www.who.int/nutrition/publications/code_ english.pdf>, accessed 23 October 2014.

\section{Concluding Observations of the Committee on the Rights of the Child}

Concluding Observations to Denmark, UN Doc. CRC/C/DNK/CO/4, 7 April 2011.

Concluding Observations to Morocco, UN Doc. CRC/C/MAR/CO/3-4, 19 September 2014.

Concluding Observations to Panama, UN Doc. CRC/C/PAN/CO/3-4, 21 December 2011.

Concluding Observations to Thailand, UN Doc. CRC/C/THA/CO/3-4, 17 February 2012. 


\section{Policy, planning and programmes}

Committee on the Rights of the Child, General Comment no. 5, General measures of implementation of the Convention on the rights of the Child (arts. 4, 42, 44, para. 6), UN Doc. CRC/GC/2003/5, 27 November 2003.

Council Of Europe, Corporate social responsibility in the field of human rights - Proposals and suggestions of issues for further consideration (updated version, June 2014 (CDDH-CORP(2014)007add.), <www.coe.int/t/dghl/standardsetting/ hrpolicy/other_committees/hr_and_business/Documents/CDDH-CORP(2014)007add_en\%20(2).pdf>, accessed 18 October 2014.

European Commission, A renewed EU strategy 2011-14 for Corporate Social Responsibility, 2011, <http://ec.europa.eu/ enterprise/policies/sustainable-business/files/csr/new-csr/act_en.pdf>, accessed 21 October 2014.

Graf, Andreas, Developing National Action Plans on Business and Human Rights, Swisspeace, 04/2013, <www.swisspeace. ch/fileadmin/user_upload/Media/Publications/Essentials/Essential_4_2013.pdf>, accessed 21 October 2014.

International Corporate Accountability Roundtable (ICAR), Danish Institute for Human Rights (DIHR), National Action Plans on Business and Human Rights: A Toolkit for the Development, Implementation, and Review of State Commitments to Business and Human Rights Frameworks, June 2014, <http://accountabilityroundtable.org/wp-content/uploads/2014/06/ DIHR-ICAR-National-Action-Plans-NAPs-Report3.pdf>, accessed 8 January 2015.

Irish Department of Children and Youth Affairs, Better Outcomes, Brighter Futures: the National Policy Framework for Children and Young People 2014-2020, <www.dcya.gov.ie/viewdoc.asp?fn=\%2Fdocuments\%2Fpolicy\%2Fchildandyou ngpolicyframework.htm>, accessed on 21 October 2014.

Report of the Working Group on the issue of human rights and transnational corporations and other business enterprises to the UN General Assembly, UN Doc. A/69/263, 5 August 2014.

UNICEF East Asia and Pacific Regional Office, ADB, The Role of Non-State Providers in Delivering Basic Social Services for Children - Workshop Report, 2010, <wWW.unicef.org/eapro/NSP_Workshop_ReportJuly_14_FINAL.pdf>, accessed 22 October 2014.

United Nations Children's Fund, Save the Children, Children's rights in Policies and Codes of Conduct, UNICEF, Geneva, December 2013, <www.unicef.org/csr/css/Children_s_Rights_in_Policies_26112013_Web.pdf>, accessed 21 October 2014.

United Nations Global Compact, Office of the High Commissioner for Human Rights, A Guide for Business: How to develop a human rights policy, United Nations Global Compact, June 2011, <www.ohchr.org/Documents/Publications/ DevelopHumanRightsPolicy_en.pdf>, accessed 21 October 2014.

United Nations Working Group on Business and Human Rights, Guidance on National Action Plans on Business and Human Rights, Version 1.0, December 2014, <www.ohchr.org/Documents/Issues/Business/UNWG_\%20NAPGuidance.pdf>, accessed 5 January 2015.

\section{Websites}

Finnish National Action Plan on Business and Human Rights, October 2014, <www.tem.fi/files/41214/TEMjul_46_2014_ web_EN_21102014.pdf>, accessed 24 October 2014.

Global Witness, New Chinese Guidelines offer mineral companies chance to reduce conflict, corruption risks and show value to host communities, 24 October 2014, <www.globalwitness.org/library/new-chinese-guidelines-offer-mineralcompanies-chance-reduce-conflict-corruption-risks-and-0>, accessed 24 December 2014.

Polish Agency for Enterprise Development, Swiss-Polish Cooperation Programme, <http://en.parp.gov.pl/index/ index/2016>, accessed 18 October 2014.

United Kingdom Foreign and Commonwealth Office, Human Rights and Democracy Programme, 3 February 2014, <wWW.gov.uk/human-rights-and-democracy-programme>, accessed 16 October 2014.

United States Department of State, DRL Programs, <www.state.gov/j/drl/p/index.htm>, accessed 16 October 2014. 


\section{Research and data collection}

Committee on the Rights of the Child, General Comment no. 5, General Measures of implementation of the Convention on the Rights of the Child (arts. 4, 42, and 44, para. 6), UN Doc. CRC/GC/2003/5, 27 November 2003.

Committee on the Rights of the Child, Guidelines on the inclusion of statistical information and data in periodic reports to be submitted by States parties under article 44, paragraph 1(b), of the Convention, para. 1, Annex to Treaty-specific guidelines regarding the form and content of periodic reports to be submitted by States parties under article 44, paragraph 1 (b), of the Convention on the Rights of the Child, UN Doc. CRC/C/58/Rev.2, 23 November 2010.

Lansdown, Gerison, Promoting Children's Participation in Democratic Decision-Making, Innocenti Insight 6 , UNICEF Office of Research - Innocenti, 2001, <www.unicef-irc.org/publications/pdf/insight6.pdf>, accessed 5 December 2014.

Office of the High Commissioner for Human Rights, Human Rights Indicators, A guide to Measurement and Implementation, United Nations, 2012, <wWw.ohchr.org/Documents/Publications/Human_rights_indicators_en.pdf>, accessed 21 October 2014.

Office of the High Commissioner for Human Rights, Principles and Guidelines for a Human Rights Approach to Poverty reduction Strategies, <wWw.ohchr.org/Documents/Publications/PovertyStrategiesen.pdf>, accessed 21 October 2014.

Rishmawi, Mervat, "Article 4: the Nature of States Parties' Obligations", in A. Alen et al. (Eds.) A Commentary to the United Nations Convention on the Rights of the Child, Martinus Nijhoff Publishers, Leiden, 2006.

United Nations Children's Fund, Child Labour and UNICEF in Action: Children at the Centre, 2014, <www.unicef.org/ protection/files/Child_Labour_and_UNICEF_in_Action.pdf>, accessed 16 October 2014.

\section{Websites}

Government of the Netherlands, Putting Corporate Social Responsibility (CSR) into Practice, <Www.government.nl/issues/ corporate-social-responsibility-csr/putting-corporate-social-responsibility-csr-into-practice>, accessed 19 October 2014.

\section{Monitoring}

Committee on the Rights of the Child, General Comment no. 2: The Role of Independent National Human Rights Institutions in the Promotion and Protection of the Rights of the Child, UN Doc. CRC/C/GC/2, 15 November 2002.

Committee on the Rights of the Child, General Comment no. 5, General Measures of implementation of the Convention on the Rights of the Child (arts. 4, 42, and 44, para. 6), UN Doc. CRC/GC/2003/5, 27 November 2003.

Committee on the Rights of the Child, Revised guidelines regarding the initial reports to be submitted by State parties under article 8, paragraph 1 of the Optional Protocol to the Convention on the Rights of the Child on Involvement of Children in Armed Conflict, UN Doc. CRC/C/OPAC/2, 19 October 2007.

Committee on the Rights of the Child, Revised guidelines regarding the initial reports to be submitted by State parties under article 12, paragraph 1 of the Optional Protocol to the Convention on the Rights of the Child on the sale of children, child prostitution and child pornography, UN Doc. CRC/C/OPSC/2, 3 November 2006.

Committee on the Rights of the Child, Treaty-specific guidelines regarding the form and content of periodic reports to be submitted by States parties under article 44, paragraph 1 (b) of the Convention on the Rights of the Child, UN Doc. CRC/C/58/Rev.2, 23 November 2010.

De Albuquerque, Catarina, On the Right Track - Good practices in realizing the rights to water and sanitation, Lisbon, 2012, <www.ohchr.org/Documents/Issues/Water/BookonGoodPractices_en.pdf>, accessed 5 December 2014.

International Commission of Jurists, Conectas, Acesso à Justiça: Violações de Direitos Humanos por Empresas: Brasil, ICJ and Conectas, Geneva, 2011.

International Co-ordinating Committee of National Institutions for the Promotion and Protection of Human Rights (ICC), The Edinburgh Declaration, 10 October 2010, <www.ohchr.org/Documents/AboutUs/NHRI/Edinburgh_Declaration_ en.pdf>, accessed 21 October 2010.

Lansdown, Gerison, Promoting Children's Participation in Democratic Decision-Making, Innocenti Insight 6, UNICEF Office of Research - Innocenti, 2001, <www.unicef-irc.org/publications/pdf/insight6.pdf>, accessed 5 December 2014. 
Office of the High Commissioner for Human Rights, Professional Training Series No. 4 (Rev.1), National Human Rights Institutions, History, Principles, Roles and Responsibilities, United Nations, New York and Geneva, 2010, <www.ohchr. org/Documents/Publications/PTS-4Rev1-NHRI_en.pdf>, accessed 21 October 2014.

Principles Relating to the Status of National Institutions ("Paris Principles"), <www.ohchr.org/Documents/Publications/ PTS-4Rev1-NHRI_en.pdf>, accessed 9 April 2014.

Report of the Special Rapporteur in the field of cultural rights, UN Doc. A/69/286, 8 August 2014.

Sedletzki, Vanessa, Championing Children's Rights: A global study of independent human rights institutions for children - Summary Report, UNICEF - Office of Research, Florence, 2012.

Sedletzki, Vanessa, Championing Children's Rights: A global study of independent human rights institutions for children, UNICEF - Office of Research, Florence, 2013.

United Nations Working Group on the issue of human rights and transnational corporations and other business enterprises, The UN Working Group on Business and Human Right's work on individual cases of alleged human rights violations and abuses, March 2014, <wWw.ohchr.org/Documents/Issues/Business/WGBrief_Communications_with_States_and_ non-State_actors_12.03.2014.pdf>, accessed 22 October 2014.

United Nations Children's Fund, Implementation Handbook for the Convention on the Rights of the Child, Fully revised third edition, UNICEF, Geneva, 2007, <WWw.unicef.org/publications/index_43110.html>, accessed 9 October 2014.

\section{Websites}

Kenya National Human Rights Commission, Report of the Malindi Inquiry, <www.knchr.org/Portals/0/Reports/Malindi_ Inquiry.pdf>, accessed 17 October 2014.

Special Procedures of the Human Rights Council, <www.ohchr.org/en/HRBodies/SP/Pages/Welcomepage.aspx>, accessed 21 October 2014.

\section{Concluding Observations of the Committee on the Rights of the Child}

Concluding Observation to Lebanon, UN Doc. CRC/C/LBN/CO/3, 8 June 2006.

Concluding Observations to Myanmar, UN Doc. CRC/C/MMR/CO/3-4, 14 March 2012.

\section{Raising awareness}

Committee on the Rights of the Child, General Comment no. 5, General Measures of implementation of the Convention on the Rights of the Child (arts. 4, 42, and 44, para. 6), UN Doc. CRC/GC/2003/5, 27 November 2003.

Plan International, A toolkit for monitoring and evaluating children's participation, 2014, <https://plan-international.org/ files/global/publications/participation/m-e-toolkit-booklet-1.pdf>, accessed 30 May 2014.

The Protection Project, Best Practices in Combating Trafficking in Persons: The Role of Civil Society, 2012, <www.ungift. org/doc/knowledgehub/resource-centre/CSOs/100-Best-Practices-in-Combating-TIP.pdf>, accessed 18 October 2014.

Vučković Šahović, Nevena, The Role of Civil Society in Implementing the General Measures of the Convention on the Rights of the Child, Innocenti Working Paper No.2010-18, UNICEF Innocenti Research Centre, Florence, 2010.

\section{Websites}

European Financial Coalition against Commercial Sexual Exploitation of Children Online, <www.europeanfinancialcoalition. eu>, accessed 18 October 2014.

Financial Coalition Against Child Pornography (Sweden), <www.financialcoalition.se>, accessed 18 October 2014.

Financial Coalition Against Child Pornography, <www.icmec.org/missingkids/servlet/PageServlet? LanguageCountry=en_ X1\&Pageld=3064>, accessed 18 October 2014.

Foreign \& Commonwealth Office, UK Trade \& Investment, Information for UK businesses on how to identify and guard against security and political risks when trading overseas, 15 October 2014, <www.gov.uk/government/collections/ overseas-business-risk>, accessed 17 October 2014. 
Government of the Netherlands, Putting Corporate Social Responsibility into Practice, <www.government.nl/issues/ corporate-social-responsibility-csr/putting-corporate-social-responsibility-csr-into-practice>, accessed 17 October 2014.

Institute for Human Rights and Business, Shift and European Commission, Human Rights Sector Guides, <www.ihrb. org/publications/reports/ec-sector-guides>, accessed 17 October 2014.

MVO Nederland, CSR Risk Check, <www.mvorisicochecker.nl/en>, accessed 23 October 2014.

Nordic Council of Ministers, Ministry of Business and Growth Denmark and Confederation of Danish industry, CSR compass, < wwW.csrcompass.com>, accessed 17 October 2014.

United States Department of Labor, Child Labor, <www.dol.gov/ilab/issues/child-labor>, accessed 17 October 2014.

\section{Remedies}

Basic Principles and Guidelines on the Rights to Remedy for Victims of Gross Violations of International Human Rights Law and Serious Violations of International Humanitarian Law, United Nations General Assembly Resolution 60/147, 16 December 2005.

Committee on the Rights of the Child, General Comment no. 11, Indigenous children and their rights under the convention, UN Doc. CRC/C/GC/11, 12 February 2009.

Committee on the Rights of the Child, General Comment no. 14 on the right of the child to have his or her best interests taken as a primary consideration (art. 3, para. 1), UN Doc. CRC/C/GC/14, 29 May 2013.

Committee on the Rights of the Child, General Comment no. 2, The role of independent national human rights institutions in the promotion and protection of the rights of the child, UN Doc. CRC/C/GC/2, 15 November 2002.

Committee on the Rights of the Child, General Comment no. 5, General measures of implementation of the Convention on the rights of the Child (arts. 4, 42, 44, para. 6), UN Doc. CRC/GC/2003/5, 27 November 2003.

Council of Europe, Guidelines of the Committee of Ministers of the Council of Europe on child friendly justice, 2010, <https:// wcd.coe.int/ViewDoc.jsp?Ref=CM/Del/Dec(2010)1098/10.2abc\&Language $=$ lanEnglish\&Ver $=$ app6\&Site =CM\&BackCol orlnternet $=$ C3C3C3\&BackColorIntranet=EDB021\&BackColorLogged=F5D383 $>$, accessed 22 October 2014.

CRIN, Child-Friendly Justice and Children's Rights, 2011, <www.crin.org/docs/Child-Friendly\%20Justice\%20and\%20 Children's\%20Rights.pdf>, accessed 22 October 2014

Grandjaen, Anne, No Rights Without Accountability: Promoting Access To Justice For Children, IDLO Legal Empowerment Working Papers. Paper No. 10, International Development Law Organization, 2010, <www.unicef.org/ceecis/LEWP_ Grandjean-1.pdf>, accessed 22 October 2014.

International Commission of Jurists, Acceso a la Justicia: Casos de Abusos de Derechos Humanos por parte de empresas: Colombia, ICJ, Geneva, 2010.

International Commission of Jurists, Conectas, Acesso à Justiça: Violações de Direitos Humanos por Empresas: Brasil, ICJ and Conectas, Geneva, 2011.

International Commission of Jurists, Needs and Options for a New International Instrument on Business and Human Rights, Geneva, June 2014, <www.icj.org/business-and-human-rights-need-international-legally-binding-instrumentsicj-report>, accessed 20 October 2014.

International Co-Ordinating Committee of National Institutions for the Promotion and Protection of Human Rights, The Edinburgh Declaration, 10 October 2010.

International Federation for Human Rights, Corporate Accountability for Human Rights Abuses: A Guide for Victims and NGOs on Recourse Mechanisms, FIDH, March 2012, <www.fidh.org/en/globalisation-human-rights/business-andhuman-rights/Updated-version-Corporate-8258>, accessed 22 October 2014.

Joint report of the Special Representative of the Secretary-General on Violence against Children and the Special Rapporteur on the Sale of Children, Child Prostitution and Child Pornography, Safe and child-sensitive counselling, complaint and reporting mechanisms to address violence against children, New York, 2012, <http://srsg.violenceagainstchildren.org/ sites/default/files/publications_final/web_safe_final.pdf>, accessed 22 October 2014. 
Mauritius Ombudsperson for Children's Office, Annual Report 2010, Chapter IX - Complaints, Investigations and Selected Cases, <http://oco.gov.mu/English/Documents/report2010/chap9.pdf>, accessed 24 October 2014.

O'Donnell, Daniel, The Right of Children to be Heard: children's right to have their views taken into account and to participate in legal and administrative proceedings, Innocenti Working Paper, Innocenti Research Centre, Florence, 2009, $<$ www.unicef-irc.org/publications/pdf/iwp_2009_04.pdf>, accessed 22 October 2014.

Office of the High Commissioner for Human Rights, Access to Justice for Children, Report of the United Nations High Commissioner for Human Rights, UN Doc. A/HRC/25/35, 16 December 2013.

Office of the High Commissioner for Human Rights, Human Rights in the Administration of Justice: A Manual on Human Rights for Judges, Prosecutors and Lawyers, Chapter 3: The Major Regional Human Rights Instruments and the Mechanisms for Their Implementation, United Nations, Geneva and New York, 2003, <www.ohchr.org/Documents/ Publications/training9chapter3en.pdf>, accessed 22 October 2014.

Rees, Caroline, Mediation in Business-Related Human Rights Disputes: Objections, Opportunities and Challenges, Working Paper No. 56, Harvard Kennedy School, February 2010, <www.hks.harvard.edu/m-rcbg/CSRI/publications/ workingpaper_56_rees.pdf>, accessed 22 October 2014.

Report of an Expert Workshop entitled "Business Impacts and Non-judicial Access to Remedy: Emerging Global Experience" held in Toronto in 2013, Addendum to the Report of the Working Group on the issue of human rights and transnational corporations and other business enterprises, UN Doc. A/HRC/26/25/Add.3, 28 April 2014.

Sedletzki, Vanessa, Championing Children's Rights: A global study of independent human rights institutions for children - Summary Report, UNICEF - Office of Research, Florence, 2012.

Sedletzki, Vanessa, Championing Children's Rights: A global study of independent human rights institutions for children, UNICEF - Office of Research, Florence, 2013.

Skinner, Gwynne et al., The Third Pillar: Access to Judicial Remedies for Human Rights Violations by Transnational Business, ICAR, CORE and ECCJ, 2013, <http://accountabilityroundtable.org/wp-content/uploads/2013/02/The-ThirdPillar-FINAL.pdf>, accessed 22 October 2014.

United Nations Basic Principles on the Role of Lawyers, adopted by the Eighth United Nations Congress on the Prevention of Crime and the Treatment of Offenders, Havana, Cuba, 27 August to 7 September 1990, <www.unrol.org/files/ UNBasicPrinciplesontheRoleofLawyers.pdf>, accessed 22 October 2014.

United Nations Children's Fund, Implementation Handbook for the Convention on the Rights of the Child, Fully revised third edition, UNICEF, Geneva, 2007, <WWw.unicef.org/publications/index_43110.html>, accessed 8 October 2014.

United Nations Children's Fund, Promoting equitable access to justice for all children, Insights: Child Rights in Central and Eastern Europe and Centre Asia, Issue 1/2014, <www.unicef.org/ceecis/Insights2014_on__promoting_equitable__ access_to_justice_for__all_children.pdf>, accessed 22 October 2014.

United Nations Development Programme, Programming for Justice: Access for All, a Practitioner's Guide to a Human Rights-Based Approach to Access to Justice, United Nations Development Programme, UNDP, Bangkok, 2005, <www. unrol.org/files/Justice_Guides_ProgrammingForJustice-AccessForAll.pdf>, accessed 22 October 2014.

United Nations Entity for Gender Equality and the Empowerment of Women, United Nations Children's Fund, United Nations Development Programme, Informal Justice Systems, Charting a course for human rights based engagement - Summary, UN Women, UNICEF, UNDP, 2012, <www.unicef.org/protection/files/INFORMAL_JUSTICE_SYSTEMS_ SUMMARY.pdf >, accessed 22 October 2014.

United Nations Guidelines on Justice in Matters Involving Child Victims and Witnesses of Crime, Economic and Social Council resolution 2005/20.

United Nations Office on Drugs and Crime, UN Principles and Guidelines on Access to Legal Aid in Criminal Justice Systems, 2013, <wWw.unodc.org/documents/justice-and-prison-reform/UN_principles_and_guidlines_on_access_to_ legal_aid.pdf>, accessed 22 October 2014. 


\section{Websites}

Daily Monitor (e-paper), Government launches child helpline, 17 June 2014, <www.monitor.co.ug/News/National/ Government-launches-child-helpline/-/688334/2350832/-/necmkj/-/index.html>, accessed 20 October 2014.

IACHR, Precautionary Measures, Community of La Oroya, 31 August 2007, <www.cidh.org/medidas/2007.eng.htm>, accessed 24 October 2014.

OECD Watch, Model National Contact Point, <http://oecdwatch.org/publications-en/Publication_2531>, accessed 14 April 2014.

Republic of Uganda, Ministry of Gender, Labour and Social Development, Uganda Child Helpline, <http://childhelpline. mglsd.go.ug>, accessed 23 October 2014.

Office of High Commissioner for Human Rights, Human Rights Bodies - Complaints Procedures, <www.ohchr.org/EN/ HRBodies/TBPetitions/Pages/HRTBPetitions.aspx>, accessed 5 January 2015.

European Committee of Social Rights, International Commission of Jurists v. Portugal, Complaint No. 1/1998, 9 September 1999, <wWw.coe.int/t/dghl/monitoring/socialcharter/Complaints/CC1Merits_en.pdf>, accessed 5 January 2015.

Concluding Observations of the Committee on the Rights of the Child

Concluding Observations to Thailand, UN Doc. CRC/C/THA/CO/3-4, 17 February 2012. 
